\title{
Self-management education and regular practitioner review for adults with asthma (Review)
}

Gibson PG, Powell H, Coughlan J, Wilson AJ, Abramson M, Haywood P, Bauman A, Hensley MJ, Walters EH

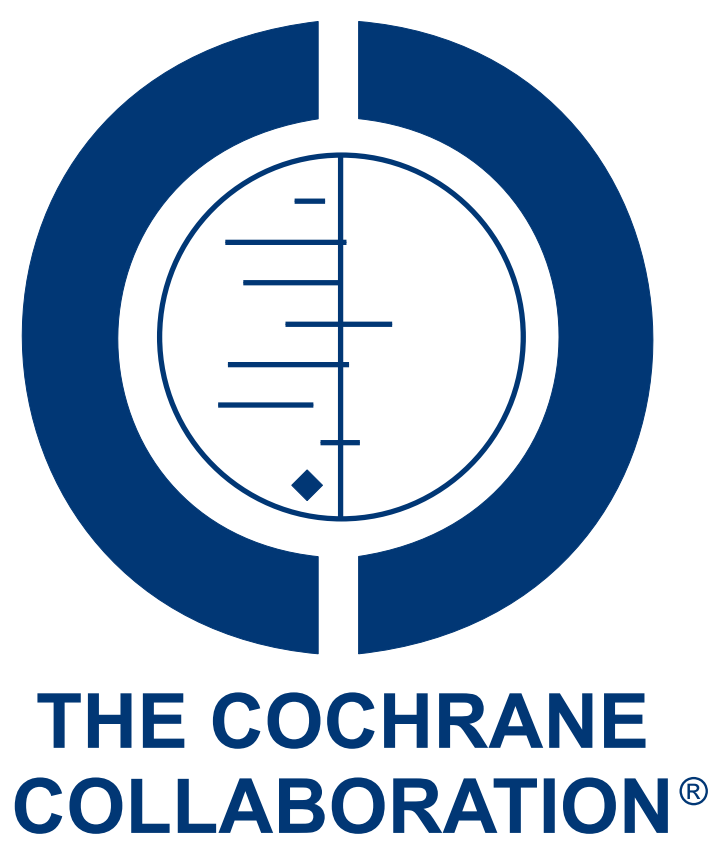

This is a reprint of a Cochrane review, prepared and maintained by The Cochrane Collaboration and published in The Cochrane Library 2008, Issue 4

http://www.thecochranelibrary.com

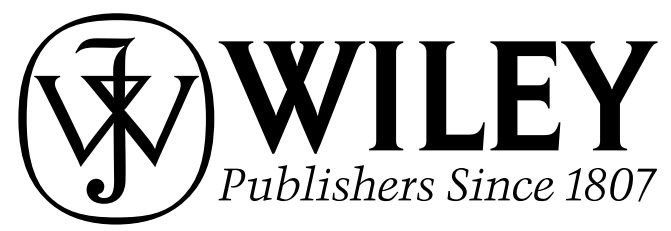

Self-management education and regular practitioner review for adults with asthma (Review)

Copyright $\odot 2008$ The Cochrane Collaboration. Published by John Wiley \& Sons, Ltd 
TABLE OF CONTENTS

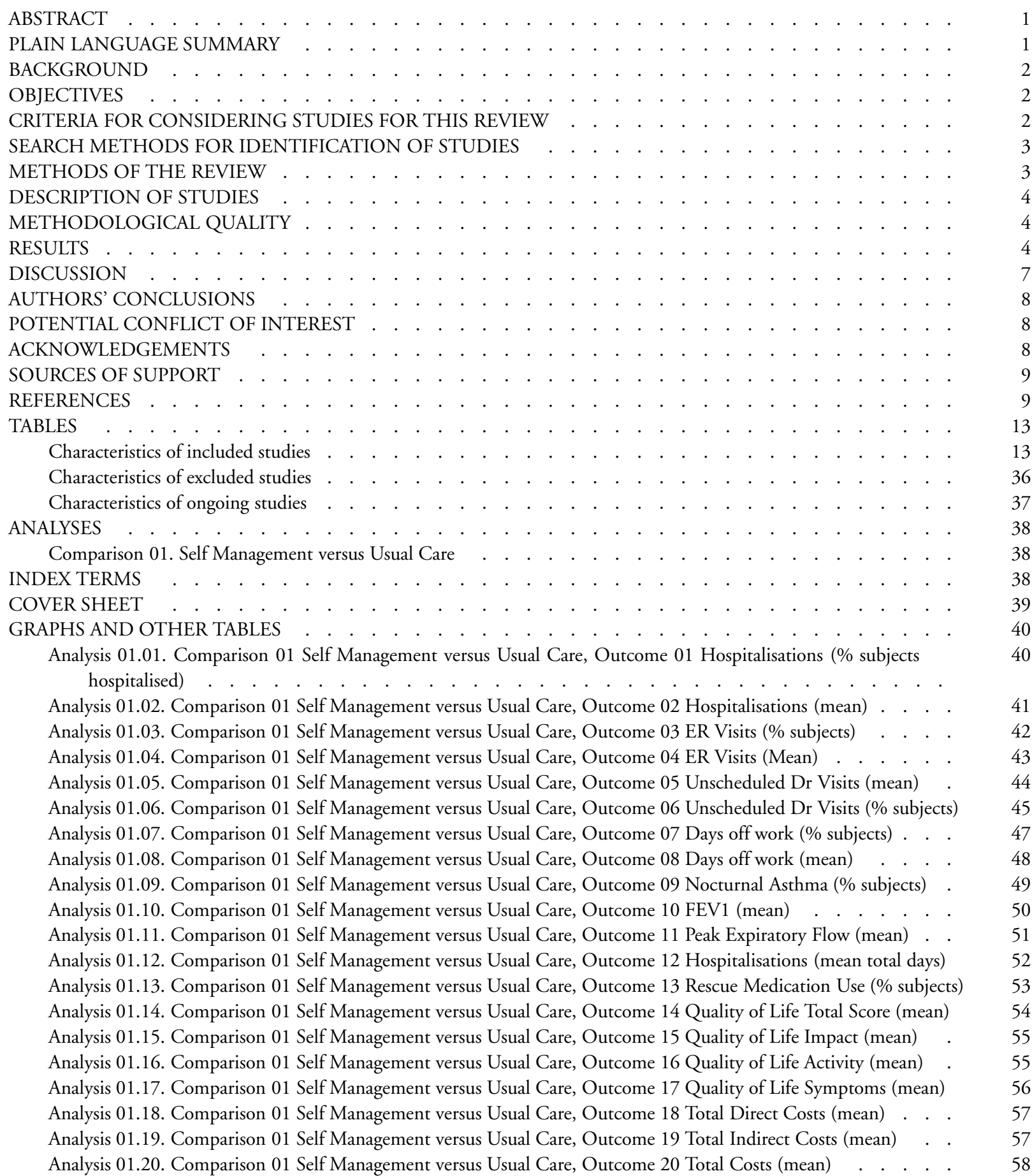

Self-management education and regular practitioner review for adults with asthma (Review)

Copyright $\odot 2008$ The Cochrane Collaboration. Published by John Wiley \& Sons, Ltd 


\title{
Self-management education and regular practitioner review for adults with asthma (Review)
}

\author{
Gibson PG, Powell H, Coughlan J, Wilson AJ, Abramson M, Haywood P, Bauman A, Hensley \\ MJ, Walters EH
}

This record should be cited as:

Gibson PG, Powell H, Coughlan J, Wilson AJ, Abramson M, Haywood P, Bauman A, Hensley MJ, Walters EH. Self-management education and regular practitioner review for adults with asthma. Cochrane Database of Systematic Reviews 2002, Issue 3. Art. No.: CD001117. DOI: 10.1002/14651858.CD001117.

This version first published online: 22 July 2002 in Issue 3, 2002.

Date of most recent substantive amendment: 12 March 2002

\section{A B S T R A C T}

\section{Background}

A key component of many asthma management guidelines is the recommendation for patient education and regular medical review. A number of controlled trials have been conducted to measure the effectiveness of asthma education programmes. These programmes improve patient knowledge, but their impact on health outcomes is less well established. This review was conducted to examine the strength of evidence supporting Step 6 of the Australian Asthma Management Plan: "Educate and Review Regularly"; to test whether health outcomes are influenced by education and self-management programmes.

\section{Objectives}

The objective of this review was to assess the effects of asthma self-management programmes, when coupled with regular health practitioner review, on health outcomes in adults with asthma.

\section{Search strategy}

We searched the Cochrane Airways Group trials register and reference lists of articles.

\section{Selection criteria}

Randomised trials of self-management education in adults over 16 years of age with asthma.

\section{Data collection and analysis}

Two reviewers assessed trial quality and extracted data independently. We contacted study authors for confirmation.

\section{Main results}

We included thirty six trials, which compared self-management education with usual care. Self-management education reduced hospitalisations (relative risk (RR) $0.64,95 \%$ confidence interval (CI) 0.50 to 0.82 ); emergency room visits (RR 0.82 , $95 \%$ CI 0.73 to 0.94 ); unscheduled visits to the doctor (RR $0.68,95 \%$ CI 0.56 to 0.81 ); days off work or school (RR 0.79 , 95\% CI 0.67 to 0.93 ); nocturnal asthma (RR $0.67,95 \%$ CI 0.0 .56 to 0.79 ); and quality of life (standard mean difference 0.29 , CI 0.11 to 0.47 ). Measures of lung function were little changed.

\section{Authors' conclusions}

Education in asthma self-management which involves self-monitoring by either peak expiratory flow or symptoms, coupled with regular medical review and a written action plan improves health outcomes for adults with asthma. Training programmes that enable people to adjust their medication using a written action plan appear to be more effective than other forms of asthma self-management.

\section{PLAIN LANGUAGESUMMARY}

Asthma self management education is of significant benefit to patients.

Self-management education and regular practitioner review for adults with asthma (Review)

Copyright ( 2008 The Cochrane Collaboration. Published by John Wiley \& Sons, Ltd 
Guidelines for the treatment of asthma recommend that patients be educated about their condition, obtain regular medical review, monitor their condition at home with either peak flow or symptoms and use a written action plan. The results of trials comparing asthma self-management education to usual care were combined. These results showed that asthma sufferers who were educated about their asthma, visited the doctor regularly and who used a written action plan had fewer visits to the emergency room; less hospital admissions; better lung function; improvement in peak expiratory flow; fewer symptoms; and used less rescue medication.

\section{B A C K G R O U N D}

The burden of illness from asthma is high and increasing (Peat 1994). There are problems with the delivery of care, which include undertreatment with corticosteroids, limited knowledge, and poor asthma management skills amongst patients with severe asthma ( Gibson 1993a). Asthma management guidelines have been developed in many countries to assist in the application of standardised, high-quality medical care (Woolcock 1989). These guidelines rely on expert opinion with variable reporting of their evidence base (Gibson 1993b).

A key component of many asthma management guidelines, including Part 1 of the Six-Part Asthma Management Program proposed by the International Consensus Report on diagnosis and Treatment of Asthma (Anonymous 1992), is the recommendation for patient education and regular medical review. Education is considered to be necessary "to help patients gain the motivation, skills and confidence to control their asthma" (Anonymous 1996). A narrative review of asthma education has emphasised the need for asthma education and suggested successful strategies (Clark 1993). A number of controlled trials have been conducted to identify the effectiveness of asthma education and selfmanagement programmes. Whilst there is general agreement that these programmes improve patient knowledge, the impact that this may have on health outcomes is less well acknowledged. For example, a review of paediatric education programmes failed to identify a positive benefit on asthma admissions, doctor visits, or school absenteeism (Bernard-Bonnin 1995). The influence of programme characteristics on health outcomes has not been examined in adults. This review was conducted to address these issues. Specifically, it examined the strength of evidence supporting Step 6 of the Australian Asthma Management Plan, "Educate and Review Regularly" in order to identify whether health outcomes are influenced by asthma education and self-management programmes.

A companion review has dealt with trials of limited (information only) education interventions (Gibson 1998) and concluded that education did not have a significant effect when administered without an action plan, self-monitoring or regular review.

\section{O B J E C T I VES}

This study aimed to evaluate the literature supporting Step 6 of the Australian Asthma Management Plan (AAMP), "Educate and
Review Regularly.” The specific questions addressed are:

(1) Do asthma self-management education and regular review (by doctor or nurse practitioner) lead to improved health outcomes in asthma?

(2) What are the characteristics of those programmes which lead to measurable changes in health outcomes?

\section{CRITERIA FOR CONSIDERING STUDIES FOR THIS REVIEW}

\section{Types of studies}

Studies were included if they were randomised controlled trials (RCTs) or quasi-randomised controlled trials (CCTs) which studied the effects of asthma education and self-management on health outcomes in adults with asthma.

\section{Types of participants}

Predominantly adults (> 16 years old) with asthma (defined by doctor's diagnosis or objective criteria or according to American Thoracic Society guidelines).

\section{Types of intervention}

We categorised the interventions according to whether or not they involved asthma education, self-monitoring of peak expiratory flow or symptoms, regular medical review and a written action plan.

\section{INTERVENTION CHARACTERISTICS:}

Patient Asthma Education: a programme which transfers information about asthma in any of these forms: written, verbal, visual or audio. It may be interactive or non-interactive, structured or unstructured. Minimal education is characterised by the provision of written material alone or the conduct of a short unstructured verbal interaction between a health provider and a patient where the primary goal is to improve patient knowledge and understanding of asthma. Maximal education is considered to be structured with the use of both interactive and non-interactive modes of information transfer. The content of the education must be related to asthma and its management.

Self-monitoring: consists of the regular measurement of either peak expiratory flow or symptoms. It is further characterised by the recording (or not) of those measurements in a diary. 
Regular Review: conists of regular consultation with a doctor during the intervention period for the purpose of reviewing the patients' asthma status and medications. This may occur either as a formal part of the intervention or the patients may be advised to see their own doctor on a regular basis. Interventions are classified as having "regular review" either inside the programme (if the patients were seen as a part of the programme) or outside the programme (if the patients were merely advised to seek regular medical review).

Written Action Plan: an individualised written plan produced for the purpose of patient self-management of asthma exacerbations. The action plan is characterised by being individualised to the patient's underlying asthma severity and treatment. It is also a written plan which informs participants about:

- when and how to modify medications in response to worsening asthma; and

- how to access the medical system in response to worsening asthma.

\section{Types of outcome measures}

Any of the following outcomes: asthma admissions, emergency room visits, doctor visits, days lost from work or school, lung function (FEV1), peak expiratory flow (PEF), use of rescue betaagonists, courses of oral corticosteroids, symptom scores, quality of life scores, costs.

\section{SEARCH METHODSFOR IDENTIFICATIONOFSTUDIES}

See: Cochrane Airways Group methods used in reviews.

We identified studies from the following sources:

Cochrane Airways Group trial register derived from MEDLINE, EMBASE, CINAHL, handsearched respiratory journals and meeting abstracts. We searched the register using the following terms: (Asthma OR wheez*) AND (education* OR self management OR self-management). We obtained the articles, and handsearched their bibliographic lists for additional articles.

\section{METHODS OF THE REVIEW}

\section{STUDY ELIGIBILITY}

Two reviewers independently coded studies from the above sources into three categories based upon the abstract/key word/title:

(1) Include: as RCT, adult, asthma, education

(2) Possible RCT but cannot determine from abstract

(3) Exclude: non-RCT or CCT, paediatric age range, doctor education.

We examined full text versions of the articles or studies in category (2) in order to define if the study met the inclusion criteria.
To investigators independently categorised study eligibility, study quality and intervention type. Agreement was examined and disagreement resolved by consensus.

We included articles if they were: randomised or quasi-randomised controlled trials; of asthma education delivered to adults (> 16 years) with asthma. We reported relevant health outcomes: hospitalisations, visits to medical practitioner, visits to emergency room, use of beta-agonists, lung functions, quality of life, symptoms score, symptoms or peak expiratory flow diary.

\section{OUTCOMES}

We assessed the following health outcomes:

- hospital admissions

- emergency room visits

- unscheduled doctor visits

- days lost from work or school

- Forced Expiratory Volume in 1 second (FEV1)

- Peak Expiratory Flow (PEF)

- use of 'rescue' (or reliever) medications

- quality of life, symptoms scores, symptom/peak flow diary

- economic data, cost, days lost from college/work.

ANALYSIS: We analysed outcomes as continuous and/or dichotomous variables, using standard statistical techniques.

(1) For continuous outcomes, the weighted mean difference (WMD) or standardised mean difference (SMD) with 95\% confidence intervals $(\mathrm{CI})$ were calculated as appropriate.

(2) For dichotomous outcomes, the relative risk (RR) was calculated with $95 \%$ CI.

We examined heterogeneity using a Chi-squared test and explored reasons for heterogeneity if appropriate.

Where appropriate, we entered data as negative values to eliminate differences in scoring scales for quality of life.

\section{PRIMARY COMPARISONS}

The primary comparison, based on the treatment of the intervention and control groups used was:

Self Management versus Usual Care;

Another review comparing different options for optimal selfmanagement is in progress.

\section{SUB-GROUP ANALYSIS}

We further divided study groups by the intensity of their intervention into one of the following categories:

(1) Optimal Self-Management which involved a written action plan for self-management of medications for exacerbations, together with self-monitoring and regular medical review;

(2) Self Monitoring and Regular Review without a written action plan; 
(3) Self Monitoring Only,

(4) Regular Review Only, and

(5) Written Action Plan but not Optimal Self-Management: These interventions included a written action plan but did not include both self-monitoring and regular review

\section{DESCRIPTION OF STUDIES}

\section{OTHER CHARACTERISTICS OF INCLUDED TRIALS:}

(i) demographics: age, gender, ethnicity, socio-economic level,

(ii) type of control: several different types of control intervention were used. These included an "intervention" of low efficacy (eg. written material only), usual medical care and (waiting list control. It is likely that a true placebo has not been used in any study.

(iii) setting of intervention: primary care vs hospital based. The severity of asthma differs in these settings and this may influence the ability to detect a change in outcome measures. For example: in a hospital based setting, the greater number of events (eg. readmission) could make it easier to detect differences than in primary care.

(iv) duration of intervention: number of sessions, hours of teaching.

(v) sample size

(vi) asthma severity

(vii) intermediate outcomes: asthma knowledge, skills.

\section{METHODOLOGICAL QUALITY}

Two reviewers independently assessed the quality of the full text versions of all included papers using the Cochrane system. Study quality was assessed according to the following criteria:

\section{CONCEALMENT OF ALLOCATION}

A: ADEQUATE if there was true randomisation, i.e. a central randomisation scheme, randomisation i.e. external person or use of coded containers/ envelopes;

B: UNCLEAR

C: INADEQUATE if there was alternate allocation, reference to case record number, date of birth, day of the week, or an open list of random numbers;

Additional quality variables recorded were:

- blinding of interventions

- withdrawals/ dropouts

- blinding of outcome assessment.

\section{R E S U L T S}

INCLUSION
We identified 101 papers describing 87 potentially relevant studies of asthma education in adults. We obtained full text versions of these papers, and two reviewers independently assessed them. We agreed to include 45 papers describing 36 randomised controlled trials in this review.

Forty seven studies were excluded for the following reasons: the participants had smoking-related chronic obstructive airway disease and not asthma (two); the methodological criteria were not met (11); background data only reported (two); the intervention did not include education (7); or was assessing inhaler technique only (3); the outcome measured was not appropriate (two); the interventions were not patient education (two); two interventions were compared without a control group (9) or the interventions were information-only education; and did not include elements of self-management or behavioural change (ten). The informationonly trials were reported in a previous review and the comparisons of two interventions form the basis of a third review. Two studies are ongoing and one is waiting assessment. The results of this review are thus derived from thirty-six RCTs of patient education and self-management in adults with asthma.

\section{AUTHOR VERIFICATION}

We made an attempt to contact all authors for verification of methodological quality, classification of the intervention(s) and of outcomes data. Replies were received from thirteen authors who are listed in the acknowledgements section. Two were returned to sender (Snyder 1987; Huss 1992). We attemped to contact the second author if we were unsuccessful in contacting the first author.

\section{INTERVENTIONS}

The content of the asthma self-management interventions described in the 36 studies included:

- education $(\mathrm{n}=36,100 \%)$

- self-monitoring of symptoms and/or peak expiratory flow $(\mathrm{n}=$ $33,92 \%)$

- regular review of treatment and asthma severity by a medical practitioner $(\mathrm{n}=24,67 \%)$

- written action plan $(\mathrm{n}=18,50 \%)$.

\section{COMPARISONS:}

Self-management was compared with a usual care control in all 36 studies. These studies fell into five subgroups according to the type of self-management intervention:

(1a) Optimal self management $(\mathrm{n}=15)$,

(1b) Self monitoring and regular review $(\mathrm{n}=7)$,

(1c) Self monitoring only $(\mathrm{n}=10)$,

(1d) Regular Review only $(\mathrm{n}=2)$ and

(1e) Written action plan but not optimal self management $(\mathrm{n}=2)$

Some degree of patient education was provided in all of the above 36 trials included in this comparison. As education has been shown 
not to have a significant impact on objective health outcomes when administered without an action plan, self monitoring or regular review (Gibson 1998), education was not reflected in sub-group analysis.

\section{CONTROL COMPARISONS}

The participants in the control groups received 'usual care' which may have included a variety of interventions. The descriptions of 'usual care' included no intervention, education, self monitoring, or regular medical review. No control group received a written action plan. In some cases, the nature of 'usual care' was not specified. The nature of the control intervention did not exclude a study from this review. Control groups received education about asthma in $12(33 \%)$ studies. Self monitoring was performed intermittently for outcome assessment in seven (22\%) studies, continuously in four $(11 \%)$ and provision of a peak flow meter and encouragement of its use occurred in one (3\%). Eleven $(31 \%)$ of the control groups were advised to seek medical review, generally outside the programme.

\section{SUBJECTS/SETTING}

6090 participants were randomised into 36 trials. Thirty four studies reported that 4593 participants completed the trial. The reported drop out rates ranged from $0 \%$ to $54 \%$.

Participants were recruited from a variety of settings:

- Hospital $(n=6)$

- Emergency Room ( $\mathrm{n}=3)$

- Hospital and Emergency Room ( $\mathrm{n}=1)$

- Outpatient Clinic $(\mathrm{n}=12)$

- General Practice $(\mathrm{n}=5)$

- Community Setting $(\mathrm{n}=6)$

- Hospital and Clinic $(\mathrm{n}=1)$

- Outpatients and General Practice $(\mathrm{n}=1)$

- $\operatorname{HMO}(\mathrm{n}=1)$

\section{OUTCOMES: SELF MANAGEMENT VERSUS USUAL} CARE

The list below describes the measurement and reporting of outcomes from the included studies.

Measured and Reported (measured but not reported)

- Hospitalisations 18 (6)

- ER visits 20 (3)

- Unscheduled Dr visits 12 (6)

- Days off work or school 16 (4)

- Nocturnal Asthma 7 (4)

- Disrupted days 2 (6)
- FEV1 8 (2)

- PEFR 14 (2)

- Oral corticosteroids 3 (1)

- Quality of life 7(3)

- Cost 4

\section{HOSPITALISATIONS}

Asthma self-management education led to a significant reduction in the proportion of participants who were hospitalised for asthma. Eighteen studies provided data of which 12 could be included in a meta analysis. Approximately $11.4 \%$ of participants in the control groups required hospitalisation for asthma exacerbations during the study periods. This was reduced to $7.1 \%$ by asthma self-management education (RR $0.64 ; 95 \%$ CI 0.50 to 0.82 ). We performed a sub-group analysis to examine the effects of different types of self-management education on hospitalisation for asthma. Optimal self-management involving provision of a written action plan led to a significant reduction in hospitalisations for asthma (RR 0.58; 95\% CI 0.43 to 0.77 ), however there was insufficient power to compare the subgroups with less intensive interventions. There was no significant difference in mean hospitalisations reported in five studies and no significant difference from baseline was reported in one but data not given (Blixen 2001).

\section{EMERGENCY HOSPITAL VISITS}

There were 20 studies that examined the effect of self-management education on emergency room (ER) visits for asthma, thirteen providing dichotomous data, nine the mean number of visits, three reporting both and one as the number of visits. The proportion of participants who required ER visits was $24.5 \%$ in the usual care group. Overall, there was a significant effect for self-management education to reduce the proportion of asthmatics needing ER visits (RR 0.82; 95\% CI 0.73 to 0.94 ). Optimal self-management education led to a significant reduction in ER visits (RR 0.78; 95\% CI 0.67 to 0.91 ), as did the two interventions which included regular review of medications (RR 0.37; 0.14, 0.99). Mean ER visits were examined in eight studies suitable for meta-analysis. There was a significant effect favouring self-management (SMD -0.36; 95\% CI -0.5 to -0.21 ), however significant heterogeneity was present (Chi Sq 8.66, p < 0.05).

Two further studies measured this outcome but did not report the results and one study reported no significant difference in ER visits from baseline (Blixen 2001)

\section{UNSCHEDULED DOCTOR VISITS}

Eleven studies reported results for the effects of self management education on unscheduled doctors visits suitable for meta-analysis; seven as the proportion of participants requiring one or more visits, and seven as the mean number of visits, with three studies reporting both. When reported as the number of participants there was a significant reduction in unscheduled visits (RR 0.68; $95 \%$ CI 0.56 to 0.81 ). However there was significant heterogeneity in 
this group (Chi Sq 24.85, p < 0.05). In the seven studies which reported the mean number of visits, there was no significant effect and significant heterogeneity (Chi Sq 30.72, p < 0.05) which is discussed below.

Six further studies reported this outcome either narratively or using data not suitable for meta-analysis. Five of these studies reported no significant effect of self-management education between groups (Hilton 1986; Allen 1995; Cote 1997; Levy 2000; Blixen 2001). One study reported a significant decrease in number of consults for both the self-management and control groups (Hayward 1996). Another study did not report their results (Snyder 1987).

\section{DAYS OFF WORK}

Sixteen studies reported the effects of self-management education on days off work; seven as the number of participants who had one or more days off work or school, and thirteen as the mean number of days or absences, with five studies reporting both. Asthma self-management education led to a significant reduction in the rest of losing days off work or school due to asthma (RR 0.79; $95 \%$ CI 0.67 to 0.93 ). In the thirteen studies that reported the mean number of days off work or school or mean number of absences, there was a significant effect favouring self-management (SMD -0.18; 95\% CI -0.28 to -0.09 ). Significant heterogeneity was present (Chi Sq 26.85, p < 0.05).

\section{NOCTURNAL ASTHMA}

Nocturnal asthma was examined as an outcome in seven studies, with data from five studies contributing to a meta-analysis. Selfmanagement education reduced the proportion of participants reporting nocturnal asthma (RR $0.67 ; 95 \%$ CI 0.56 to 0.79$)$. However there was significant heterogeneity within this group (Chi Sq $107.02, p<0.05)$. In the four other studies which mentioned this outcome, but did not provide numerical data, an improvement was noted in three studies and no significant change in another.

\section{LUNG FUNCTION}

Airway function was assessed as either clinic forced expiratory volume in 1 second (FEV1) (10 studies) or peak expiratory flow (PEF) (16 studies). Of the seven studies that reported data on FEV1 and were used for meta-analysis, six were optimal self-management interventions. No significant effect of education on this variable was found. PEF was measured in 16 studies and data from 10 studies contributed to a meta-analysis. All of these data were available in absolute units ( $1 / \mathrm{min}$ ), with one exception (Jones 1995), in which the results were presented as \% predicted normal. The data tables include this trial, so the analyses used the SMD to permit aggregation. There was an overall positive effect of asthma self-management education which led to an improvement in PEF, that achieved statistical significance at $\mathrm{p}<0.05$. When this study was removed and the analysis repeated using the WMD (since all the outcomes were in the same units of measurement), the overall effect remained statistically significant. The absolute improvement in PEF was small (14.5 1/min). Significant heterogeneity was present for both the SMD analysis (Chi Sq 30.13, p < 0.05) and the WMD analysis (Chi Sq 28.77, p < 0.05).

\section{ORAL CORTICOSTEROIDS}

Four studies assessed the use of oral corticosteroids. Grampian 1994 measured the number of courses of oral corticosteroids, reporting no between group differences. Jones 1995 reported that $47 \%$ in the treatment group and $38 \%$ in the control group used oral corticosteroids. Mayo 1990, who measured the percentage of participants using chronic daily prednisone recorded a drop from $25 \%$ to $9 \%$ in the treatment group but did not record the results of the control group. de Oliveira 1999 reported no significant difference in the percentage of participants who used oral corticosteroids continuously before and after the programme for both the self-management and control groups.

\section{QUALITY OF LIFE}

Quality of life was assessed in ten studies, six of which provided mean total scores. Overall there was a significant improvement in total quality of life score for those receiving the self-management intervention (SMD 0.29;95\% CI 0.11 to 0.47 ). Significant heterogeneity was also present (Chi Sq 26.0; p < 0.05). Cote 1997 reported a significant improvement for all groups but only a clinically significant improvement ( $>0.5$ change in score) for the intervention group that received an action plan based on symptoms. No significant intergroup difference was reported by Jones 1995 but a significant within group improvement in all scores was reported for the self-management group. Knoell 1998 reported an improvement in both groups for most domains and no significant difference between the groups. Moudgil 2000 reported an improvement in score for those who received self-management education and a decrease in score for those in the control group. These differences were significant between the two groups.

Self-management intervention improved the impact domain of quality of life as reported in two studies (SMD 0.23; 95\% CI 0.02 to 0.47 ). However this was not statistically significant and heterogeneity was present (Chi Sq 12.54, p < 0.05). Four studies reported mean activity score, three that could be included in a meta-analysis resulting in a non-significant improvement in activity score. Mean symptom score for quality of life favoured the usual care group in three studies but this was not significant. Heterogeneity was present (Chi Sq 10.25, p < 0.05).

We conducted sensitivity analyses to explore reasons for heterogeneity in the quality of life total score meta-analysis.

- Asthma Severity: two studies (Lahdensuo 1996; Gallefoss 1999) included participants with mild to moderate asthma whereas four studies included moderate to severe asthma. Removal of the mild to moderate asthma severity studies from the meta-analysis did not eliminate heterogeneity (Chi Sq 14.8, p = 0.002).

- Ethnic Minority: two studies (de Oliveira 1999; Blixen 2001) studied ethnic minority groups. Removal of these studies from 
the meta-analysis did not eliminate heterogeneity (Chi-Sq 15.9, $\mathrm{p}=0.001)$.

- Questionnaire: two studies (Gallefoss 1999; Levy 2000) used the St Georges Respiratory Questionnaire to measure quality of life. Removal of these studies from the meta-analysis reduced but did not eliminate heterogeneity (Ch Sq 10.8, p = 0.013).

- Intervention Type: a written action plan was part of the intervention in three studies (Lahdensuo 1996; Gallefoss 1999; Levy 2000). Heterogeneity remained in a meta-analysis that included these studies only (Ch Sq 14.91, p = 0.006)

\section{COSTS}

Costs were assessed in four studies. Ghosh 1998 recruited participants from a hospital asthma and allergy clinic who had a greater than $15 \%$ reversal of FEV1 post bronchodilator and at least one ER visit or hospitalisation in the past 12 months. Participants were randomised to an optimal self-management programme, including a written action plan, or to usual care. The intervention included four, two hour sessions, with a social scientist, commencing during the first month following the baseline interview. Economic outcomes were measured four, eight and twelve months after baseline. Direct costs were measured in Indian Rupees and included daily medication costs, hospitalisation and ER visit costs. The costs of physician visits were excluded as these were not reported consistently. Estimates of transportation, intervention and lost production costs were also provided (Ghosh 1998).

In a trial conducted by Lahdensuo 1996, mild to moderate asthmatics were recruited from outpatients and randomised to an optimal self-management training intervention that included a written action plan or to a usual care control group that included regular medical review. Both groups were followed up every four months for one year. Direct costs, measured in Finnish marks, included counselling (instruction in self-management for the intervention group and general information in the control group), peak flow meter, drugs, doctor visits that were not related to the study and hospital admissions. Indirect costs included absence from work (Lahdensuo 1996).

Gallefoss 1999 recruited mild to moderate asthmatics from an outpatient chest clinic and randomised them to either a self-management intervention, which included self monitoring and a written action plan, or to a usual care control group. The intervention comprised two group sessions, each two hours long and one individual session, which was one to two hours with a physiotherapist and a nurse. All participants in the intervention group also received a booklet summarising the information received during the sessions. Participants were followed for 12 months. Costs were based on utilisation of care and unit costs (Norwegian Krone) and included patient co-payments and reimbursement costs from the National Health Insurance fee. Direct costs were defined as costs incurred by the healthcare system, community and family. Indirect costs included productivity loss, time costs for the individual, family, society and employer. Cost-effectiveness ratios were also estimated (Gallefoss 1999).

In an economic analysis of asthma education programmes, Neri 1996 randomised asthmatics to two different education programmes, a reduced education programme or a complete "asthma school" which involved more intense education. Both groups performed self-monitoring and were followed for one year. Direct costs included intervention costs (personnel related costs, videotape and cost of room), "per diem" costs for hospital admissions, drug costs and medical examination costs. Indirect costs were counted as the salary per day of work lost. Cost-effectiveness ratios were calculated by dividing the difference in the programme costs by the difference in reducing the outcome variables for the two programmes.

Ghosh 1998 reported a non-significant reduction in direct costs and a significant reduction in indirect costs for the self-management group when compared to the control group. Lahdensuo 1996 observed that direct costs were significantly lower for the control group, and that indirect costs were significantly lower for the self-management group. Overall, there was a significant reduction in total costs for the self-management group. Gallefoss 1999 reported non-significant trends for lower direct costs and higher indirect costs for the control group. Total costs were lower for the intervention group but this was not significant when compared to the control group. Neri 1996 reported a better outcome for the intensive education programme when calculating the cost-effectiveness ratio for asthma attacks, urgent doctor visits and days off work.

Three studies provided data on mean total, direct and indirect costs. These studies were critically appraised by a health economist (PH). The study by Ghosh 1998 excluded the costs of physician visits and was therefore not included in a meta analysis. The remaining two studies contributed to a meta analysis. As these were reported in different currencies, a standardised mean difference was used for analysis. Self-management intervention led to a significant reduction in indirect costs (SMD - $0.40 ; 95 \%$ CI -0.69 to -0.11 ) but increased direct costs (SMD 0.39; 95\% CI 0.10 to $0.68)$. Overall there was a reduction in total costs (SMD -0.26; $95 \% \mathrm{CI}-0.55$ to 0.03 ) which did not quite reach significance.

\section{I S C U S S I O N}

This review systematically evaluated 36 RCTs of self-management education for adults with asthma and found that this type of intervention leads to improved health outcomes. The studies showed that with self-management education, there was a reduction in the proportion of participants reporting hospitalisations and ER visits for asthma, unscheduled doctors visits for asthma, days lost from work due to asthma, episodes of nocturnal asthma, indirect costs and an improvement in total quality of life. The effects were 
large enough to be of both clinical and statistical significance. The review also identified a number of limitations to the current published literature which need to be considered. The interventions were described in varying detail, and included several differing factors. The system used to categorise the interventions in this review was based upon recommendations in current asthma management guidelines. Specifically, they were evaluated as to whether they included peak expiratory flow monitoring, regular medical review, and a written action plan. These are important aspects of asthma management which could be reliably evaluated from the papers. It could be useful in future work to extend this by looking in detail at the concordance of interventions with educational theory. This would require access to the precise details of interventions, which is generally not provided in publications because of space limitations.

There was variable contamination of the control groups with some aspects of self-management education. For example, peak expiratory flow monitoring was used as an outcome measure in some control groups. The effect of this would be to reduce the effect size of self-management education and hence bias against seeing an effect. Despite this, clinically meaningful effects were seen in most outcomes.

Not all papers reported outcomes in a way that could contribute to meta-analysis. We attempted to overcome this by contacting authors, but had variable success. This limits the generalisability of the results.

In some cases, outcomes were reported as continuous measures showing no treatment effect. This is probably due to the inappropriate use of continuous measures for outcomes which are not normally distributed such as hospitalisations, ER visits, doctor visits and days off work or school. Heterogeneity was found in the latter two variables. Possible explanations may be differing definitions of what constitutes an unscheduled doctor visit or a day off work or the combination of groups of differing asthma severity. It is noted that in one study (Ignacio-Garcia 1995) the control group was instructed to visit the emergency or doctor as a part of their management. This may have also contributed to the heterogeneity.

\section{A U THORS' CONCLUSIONS}

\section{Implications for practice}

Self-management education of adults with asthma results in clinically important improvements in asthma health outcomes. This is most apparent with interventions involving a written action plan, self-monitoring and regular medical review. These interventions result in a reduction in the proportions of participants who use health care services and who are bothered by nocturnal asthma and loss of work.
Self-management education that involves a written action plan, self-monitoring and regular medical review should be offered to adults with asthma.

Less intensive interventions, particularly those without a written action plan are less efficacious.

\section{Implications for research}

Optimisation of management plan: what are the core 'actions'?

(1) How much PEF/Symptom monitoring is optimal?

(2) What is the duration of effect?

(3) Is maintenance required?

(4) What forms should it take?

(5) How do the interventions conform to psycho-educational theory?

(6) What is the best form for a written action plan?

\section{POTENTIALCONFLICTOF IN TEREST}

None

\section{ACKNOWLEDGEMENTS}

We would like to thank the Cochrane Airways Group who helped with database searches, obtaining studies and translations (Steve Milan, Toby Lasserson, Anna Bara, Karen Blackhall). Thanks also to Kirsty Olsen who copy edited this review.

We would like to thank the following authors for providing information about their trials:

Dr M Abramson re Abdulwadad

Dr R Allen,

Dr I Charlton,

Dr J Cote,

Dr JM Ignacio-Garcia

Dr D Knoell

Dr A Lahdensuo

Dr K Lutteral re Yoon,

Dr J Mercer re Garrett,

Mr M Mullee re Jones

Dr M. Neri,

Dr M Sommaruga,

Dr L Tougaard,

Dr RS Zeiger,

We would also like to acknowledge:

NSW Health Cooperative Research Centre for Asthma, Australia for financial and administrative support. 


\section{SOURCES OF SUPPORT}

\section{External sources of support}

- Cooperative Research Centre for Asthma AUSTRALIA

Internal sources of support

- Hunter Area Health Service

\section{R E F E R E N C E S}

\section{References to studies included in this review}

Abdulwadud 1999 \{published data only\}

Abdulwadud O, Abramson M, Forbes A, James A, Walters EH. Evaluation of a randomised controlled trial of adult asthma education in a hospital setting. Thorax 1999;54:493-500.

Allen 1995 \{published data only\}

Allen RM, Jones MP, Oldenburg. Randomised trial of an asthma selfmanagement programme for adults. Thorax 1995;50:731-8.

Bailey 1990 \{published data only\}

Bailey WC, Richards JM, Brooks CM, Soong S, Windsor RA, et al.A randomised trial to improve self-management practice of adults with asthma. Archives of Internal Medicine 1990;150:1664-8.

Bailey WC, Richards JM, Manzella BA, Windsor RA, Brooks CM, Soong SJ. Promoting self management in adults with asthma: an overview of the UAB program. Health Education Quarterly 1987;14: $345-55$.

Windsor RA, Bailey WC, Richards JM, et al.Evaluation of the efficacy and cost effectiveness of health education methods to increase medication adherence among adults with asthma. American Journal of Public Health 1990;80:1519-21.

Bailey 1999 \{published data only\}

Bailey WC, Kohler CL, Richards JM, Windsor RA, Brooks M, Gerald LB. Asthma self-management: do patient education programs always have an impact?. Archives of Internal Medicine 1999;159:2422-8.

Berg 1997 \{published data only\}

Berg J, Dunbar-Jacob J, Sereika SM. An evaluation of a self-management program for adults with asthma. Clinical Nursing Research 1997;6(3):225-38.

Blixen 2001 \{published data only\}

Blixen CE, Hammel JP, Murphy D, Ault V. Feasibility of a nurserun asthma education program for urban African-Americans: a pilot study. Journal of Asthma 2001;38(1):23-32.

Brewin 1995 \{published data only\}

Brewin AM, Hughes JA. Effect of patient education on asthma management. British Journal of Nursing 1995;4:81-101.

Cote 1997 \{published data only\}

Cote J, Cartier A, Robichaud P, Boutin H, Malo JI. Influence of asthma education on asthma severity, quality of life and environmental control. Canadian Respiratory Journal 2000;7(5):395-400.

*Cote J, Cartier A, Robichaud P, Poutin H, Malo J, Rouleau M, et al.Influence on Asthma Morbidity of asthma education programs based on self management plans following treatment optimization. American Journal of Respiratory \& Critical Care Medicine 1997;155: 1509-14.

Cowie 1997 \{published data only\}

Cowie RL, Revitt SG, Underwood MF, Field SK. The effect of a peak flow-based action plan in the prevention of exacerbations of asthma. Chest 1997;112:1134-8.

de Oliveira 1999 \{published data only\} de Oliveira MA, Faresin SM, Bruno VF, de Bittencourt AR, Fernandes ALG. Evaluation of an educational programme for socially deprived asthma patients. European Respiratory Journal 1999;14(4): 908-14.

Gallefoss 1999 \{published data only\} Gallefoss F, Bakke PS. Cost-effectiveness of self-management in asthmatics: a 1yr follow-up randomized, controlled trial. European Respiratory Journal 2001;17:206-213.

Gallefoss F, Bakke PS. How does patient education and self-management among asthmatics and patients with chronic obstructive pulmonary disease affect medication. American Journal of Respiratory $\&$ Critical Care Medicine 1999;160:2000-5.

Gallefoss F, Bakke PS. Impact of patient education and self-management on morbidity in asthmatics and patients with chronic obstructive pulmonary disease. Respiratory Medicine 2000;94:279-87.

Gallefoss F, Bakke PS. Patient satisfaction with health care in asthmatics and patients with COPD before and after patient education. Respiratory Medicine 2000;94:1057-1064.

${ }^{*}$ Gallefoss F, Bakke PS, Kjaersgaard P. Quality of life assessment after patient education in a randomized controlled study on asthma and chronic obsructive pulmonary disease. American Journal of Respiratory \& Critical Care Medicine 1999;159:812-7.

Garret 1994 \{published data only\}

Garrett J, Fenwick JM, Taylor G, Mitchell E, Stewart J, Rea H. Prospective controlled evaluation of the effect of a community based asthma education centre in a multiracial working class neighbourhood. Thorax 1994;49:976-83.

George 1999 \{published data only\} George MR, O’Dowd LC, Martin I, Lindell KO, Whitney F, Jones $\mathrm{M}$, et al.A comprehensive educational progamme improves clinical outcome measures in inner-city patients with asthma. Archives of Internal Medicine 1999;159:1710-6. 
Ghosh 1998 \{published data only\}

Ghosh CS, Ravindran P, Joshi M, Stearns SC. Reductions in hospital use from self management training for chronic asthmatics. Social Science \& Medicine 1998;46(8):1087-93.

Grampian 1994 \{published data only\} Grampian Asthma Study of Integrated Care (GRASSIC) Effectiveness of routine self monitoring of peak flow in patients with asthma. Britich Medical Journal 1994;308:564-7.

Hayward 1996 \{published data only\}

Hayward SA, Jordan M, Golden G, Levy M. A randomised controlled evaluation of asthma self management in general practice. Asthma in General practice 1996;4:11-3.

Heard 1999 \{published data only\}

Heard AR, Richards IJ, Alpers JH, Pilotto LS, Smith BJ, Black JA. Randomised controlled trial of general practice based asthma clinics. Medical Journal of Australia 1999;171:68-71.

Hilton 1986 \{published data only\}

Hilton S, Sibbald B, Anderson HR, Freeling P. Controlled evaluation of the effects of patient education on asthma morbidity in general practice. The Lancet 1986;1:26-9.

Ignacio-Garcia 1995 \{published data only\} Ignacio-Garcia JM, Gonzalez-Santos P. Asthma self-management education program by home monitoring of peak expiratory flow. American Journal of Respiratory \& Critical Care Medicine 1995;151:353-9.

Jones 1995 \{published data only\}

Jones KP, Mullee MA, Middleton M, Chapman E, Holgate ST, British Society Research Committee. Peak flow based asthma self management: a randomised controlled study in general practice. Tho$\operatorname{rax}$ 1995;50:851-7.

Knoell 1998 \{published data only\}

Knoell DL, Pierson JF, Marsh CB, Allen JN, Pathak DS. Measurement of outcomes in adults receiving pharmaceutical care in a comprehensive asthma outpatient clinic. Pharmacotherapy 1998;18(6): 1365-74.

Kotses 1995 \{published data only\}

Kotses H, Bernstein IL, Bernstien DI, et al.A self-management program for adult asthma. Part 1: development and evaluation. Journal of Allergy \& Clinical Immunology 1995;95:529-40.

Kotses 1996 \{published data only\}

Kotses H, Stout C, Mcconnaughty K, Winder JA, Creer TL. Evaluation of individualized asthma self-management programes. Journal of Asthma 1996;33:113-8.

Lahdensuo 1996 \{published data only\}

Lahdensuo A, Haahtela T, Herrala J, Kava T, Kiviranta K, Kuusisto P, et al.Randomised comparison of cost effectiveness of guided self management and traditional treatment of asthma in Finland. British Medical Journal 1998;316:1138-9.

*Lahdensuo A, Haahtela T, Herrala J, et al.Randomised comparison of guided self-management. British Medical Journal 1996;312:74852.

Levy 2000 \{published data only\}

Levy ML, Robb M, Allen J, Doherty C, Bland JM, Winter RJD. A randomized controlled evaluation of specialist nurse education following accident and emergency attendance for acute asthma. Respiratory Medicine 2000;94:900-8.
Mayo 1990 \{published data only\}

Mayo PH, Richman J, Harris HW. Results of a program to reduce admissions for adult asthma. Annals of Internal Medicine 1990;112: 864-71.

Moudgil 2000 \{published data only\}

Moudgil H, Marshall T, Honeybourne D. Asthma education and quality of life in the community: a randomised controlled study to evaluate the impact on white European and Indian subcontinent ethnic groups from socioeconomically deprived areas in Birmingham, UK. Thorax 2000;55:177-83.

Mulloy 1996 \{published data only\}

Mulloy E, Donaghy D, Quigley C, McNicholas WT. A one-year prospective audit of an asthma education programme in an outpatient setting. Irish Medical Journal 1996;89:226-8.

Neri 1996 \{published data only\}

Neri M, Migliori GB, Spanevello A, Berra D, Nicolin E, Landoni $\mathrm{CV}$, et al.Economic analysis of two structured treatment and teaching programs on asthma. Allergy 1996;51:313-9.

Schott-Baer 1999 \{published data only\}

Schott-Baer D, Christensen M. Research for practice. A pilot programme to increase self-care of adult asthma patients. Medsurg Nursing 1999;8:178-83.

Shields 1986 \{published data only\} Shields MC, Reinhard JD, Szidon JP, White PB. Effectiveness of a patient eduction program for adult asthmatics in reducing emergency room use. Clinical Research 1986;34(2).

Shields MC, Vail MJ, Reinhard JD, Szidon JP, White PB. Counseling is better accepted than classes in patient education of adult inner city asthmatics. New Health Care Systems: HMOs \& Beyond. 1986; June:289-98.

Snyder 1987 \{published data only\}

Snyder Se, Winder JA, Creer TL. Development and evaluation of an adult asthma self-managment program: Wheezers Anonymous. Journal of Asthma 1987;11:39-43.

Sommaruga 1995 \{published data only\}

Sommaruga M, Spanevello A, Migliori GB, Neri M, Callegari S, Manjani G. The effects of a cognitive behavioural intervention in asthmatic patients. Monaldi Archives for Chest Disease 1995;50:398402.

Wilson 1993 \{published data only\}

Nguyen BP, Wilson SR, German DF. Patients' perceptions compared with objective ratings of asthma severity. Annals of Allergy Asthma \& Immunology 1996;77:209-15.

Wilson-Pessano ST, et al.An evaluation of approaches to asthma self management education for adults. The AIR/Kaiser Permanente study. Health Education Quarterly 1987;14:333-43.

Wilson SR, Scamagas P, German DF, Hughes GW, Lulla S, et al.A controlled trial of two forms of self-managment education for adults with asthma. American Journal of Medicine 1993;94:564-76.

Yoon 1993 \{published data only\}

Yoon R, McKenzie DK, Bauman A, Miles DA. Controlled trial evaluation of an asthma education program for adults. Thorax 1993;48: 1110-6. 
Zeiger 1991 \{published data only\}

${ }^{*}$ Zeiger RS, Heller S, Mellon MH, Wald J. Falkoff R, Schatz M. Facilitated referral to asthma specialist reduces relapses in asthma emergency room visits. Journal of Allergy and Clinical Immunology 1991;87:1160-8.

\section{References to studies excluded from this review Abdulwadud 1997}

Abdulwadud O, Abramson M, Forbes A, James A, Light L, Thien F, Walters EH. Attendance at an asthma educational intervention: characterisitics of participants and non-participants. Respiratory Medicine 1997;91:524-9.

\section{Adams 2001}

Adams RJ, Boath K, Homan S, Campbell DA, Ruffin RE. A randomised trial of peak-flow and symptom-based action plans in adults with moderate-to-severe asthma. Respirology 2001;6:297-304.

Aiolfi 1995

Aiolfi S, Confalonieri M, Scartabellati A, Patrini G, Ghio L, Mauri F, et al.International guidelines and educational experiences in an outpatient clinic for asthma. Monaldi Archives for Chest Disease 1995; 50:477-81.

\section{Amirav 1995}

Amirav I, Goren A, Kravitz RM, Pawlowski N. Physician-tarteted program on inhaled therapy for childhood asthma. Journal of Allergy and Clinical Immunology 1995;95:818-23.

Ayres 1996

Ayres JG, Campbell LM. A controlled assessment of an asthma selfmanagement plan involving a budesonide dose regimen. European Respiratory Journal 1996;9:886-92.

Baldwin 1997

Baldwin DR, Pathak UA, King R, Vase BC, Pantin CFA. Outcome of asthmatics attending asthma clinics utilising self-management plans in general practice. Asthma in General Practice 1997;5:31-2.

\section{Bolton 1991}

*Bolton MB, Tilley BC, Kuder J, Reeeves T, Schultz LR. The cost and effectiveness of an education program for adults who have asthma. Journal of General Internal Medicine 1991;6:401-7.

Ford ME, Havstad SL, Tilley BC, Bolton MB. Health outcomes among African and American caucasian adults following a randomized trial of an asthma education program. Ethnicity \& Health 1997; 2(329-39).

\section{Boulet 1995}

Boulet LP, Boutin H, Cote J, Leblanc P, Laviolettte M. Evaluation of an asthma self-management program. Journal of Asthma 1995;32: 199-206.

\section{Charlton 1990}

Charlton I, Charlton G, Broomfield J, Mullee M. Evaluation of peak flow and symptoms only self management plans for control of asthma in general practice. British Medical Journal 1990;301:1355-9.

Cote 2001

Cote J, Bowie DM, Robichaud P, Parent J-G, Battiti L, Boulet L-P. Evaluation of two different educational interventions for adult patients consulting with an acute asthma exacerbation. American Journal of Respiratory and Critical Care Medicine 2001;163:1415-9.

\section{Cox 1993}

Cox NJM, Hendricks JC, Binkhorst Ra, Van Herwaarden CLA. A pulmonary rehabilitation program for patients with asthma and mild chronic obstructive pulmonary diseases (COPD). Lung 1993;171: 235-44.

\section{Erickson 1998}

Erickson SR, Ascione FJ, Kirking DM, Johnson CE. Use of a paging system to improve medication self-management in patients with asthma. Journal of the American Pharmaceutical Association 1998;38: 767-9.

\section{Gergen 1995}

Gergen PJ, Goldstein RA. Does asthma education equal asthma intervention?. International Archives of Allergy \& Immunology 1995; 107:166-8

\section{Graft 1991}

Graft DF. A randomised trial to improve self-management practices of adults with asthma: reviewers comments. Journal of Asthma 1991; 28:228-9.

\section{Grainger-Rousseau}

Grainger-Rousseau T-J, McElnay JC. A model for community pharmacist involvement with general practitioners in the management of asthma patients. Journal of Applied Therapeutics 1996;1:145-61.

\section{Grampian 1994b}

Grampian Asthma Study of Integrated Care (GRASSIC) Integrated care for asthma: a clinical, social, economic evaluation. British Medical Journal 1994;308:559-64.

\section{Hausen 1999}

Hausen T. Patient education-how can the long-term effect be analyzed and how long does it last? (German). Pneumologie 1999;53: 289-95.

\section{Heringa 1987}

Heringa P, Lawson L, Reda D. The effects of a structured education program on knowledge and psychomotor skills of patients using Beclomethasone Dipropionate Aerosol for Steroid Dependent Asthma. Health Education Quarterly 1987;14:309-17.

\section{Hindi-Alexander 1987}

Hindi-Alexander MC. Asthma education programs: their role in asthma morbidity and mortality. Journal of Allergy and Clinical Immunology 1986;80:492-4.

\section{Hoskins 1996}

Hoskins G, Neville RG, Smith B, Clark RA. Do self-management plans reduce morbidity in patients with asthma?. British Journal of General Practice 1996;46:169-71.

\section{Huss 1992}

Huss K, Huss RW, Squire EN, et al.Computer education for asthmatics: What efffects?. Journal of Nursing Care Quality 1992;6:5766.

\section{Jackevicius 1999}

Jackevicius CA, Chapman KR. Inhaler education do hospital based pharmacists: How much is required?. Canadian Respiratory Journal 1999;6:237-44.

\section{Janson-Bjerklie 1988} Janson-Bjerklie S, Shnell S. Effect of peak flow information on patterns of self-care in adult asthma. Heart \& Lung 1988; 17:543-9. 


\section{Jenkinson 1988}

Jenkinson D, Davison J, Jones S, Hawtin P. Comaparison of effects of a self management booklet and audio cassette for patients with asthma. British Medical Journal 1988;297:267-70.

\section{Jones 1987}

Jones PK, Jones SL, Katz J. Improving compliance for asthmatic patients visiting the emergency department using a health belief model. Journal of Asthma 1987;24:199-206.

\section{Kauppinen 1998}

*Kauppinen R, Sintonen H, Tukiainen H. One-year economic evaluation of intensive versus conventional patient education and supervision for self-management of new asthmatic patients. Respiratory Medicine 1998;92:300-7.

Kauppinen R, Sintonen H, Vilkka V, Tukianen H. Long-term (3year) economic evaluation of intensive patient education for selfmanagement during the first year in new asthmatics. Respiratory Medicine 1999;93:283-9.

Kauppinen R, Vilkka V, Sintonen H, Klaukka T, Tukianen H. Long term economic evaluation of intensive patient education during the first treatment year in newly diagnosed asthma. Respiratory Medicine 2001;95:56-63.

\section{Kelso 1995}

Kelso TM, Abou-Shala N, Neilker GM, Arheart KL, Portner TS, Self TH. Comprehensive long-term management program for asthma: effect on outcomes in adult African-Americans. American Journal of the Medical Sciences 1996;311:272-80.

Kelso TM, Self TH, Rumbak MJ, Stephens MA, Garrett W, Arheart KL. Educational and Long-Term Therapeutic Intervention in the ED: Effect on Outcomes in Adult Indigent Minority Asthmatics. American Journal of Emergency Medicine 1995;13:632-8.

\section{Klein 2001}

Klein JJ, van der Palen J, Uil SM, Zielhaus GA, Seydel ER, van Herwaarden CLA. Benefit from the inclusion of self-treatment guidelines to a self-management programme for adults with asthma. European Respiratory Journal 2001;17:386-394.

\section{LeBaron 1985}

LeBaron S, Zeltzer LK, Patner P, Kniker WT. A controlled study of education for improving compliance with Cromolyn Sodium (Intal): the importance of Physician-patient communication. Annals of Allergy 1985;55:811-8.

\section{Legorreta 2000}

Legorreta AP, leung K-M, Berkbigler D, Evans R, Liu X. Outcomes of a population-based asthma management program: quality of life, absenteeism, and utilization. Annals of Allergy Asthma \& Immunology 2000;85:28-34

\section{Lirsac 1991}

Lirsac B, Braunstein G. Randomised evaluation of two teaching methods using aerosol dosers (French). Revue des Maladies Respiratories 1991;8:559-65.

\section{Lopez-Vina 2000}

Lopez-Vina A, del Castillo-Arevalo F. Influence of peak expiratory flow monitoring on an asthma self-management education programme. Respiratory Medicine 2000;94:760-6.

\section{Maes 1988}

Maes S, Schlosser M. Changing health behaviour outcomes in asthmatic patients: A pilot intervention study. Social Science \& Medicine 1988;26:359-64.

Maiman 1979

Maiman LA, Green LW, Gibson G, MacKenzie EJ. Education for selftreatment by adult asthmatics. The Journal of the American Medical Association 1979;241:1919-22.

\section{Moldofsky 1979}

Moldofsky H, Broder I, Davies G, Leznoff A. Videotape educational program for people with asthma. Canadian Medical Association Journal 1979;120:669-72.

\section{Muhlhauser 1991}

Muhlhauser I, Richter B, Kraut D, Weske G, Worth H, Berger M. Evaluation of a structured treatment and teaching programme of asthma. Journal of Internal Medicine 1991;230:157-64.

\section{Osman 1994}

Osman LM, Abdalla MI, Beattie JAG, Ross SJ, Russell IT, Friend $\mathrm{JA}$, et al.Reducing hospital admission through computer supported education for asthma patients. British Medical Journal 1994;308: $568-71$

\section{Perdomo-Ponce 1996}

Perdomo-Ponce D, Benarroch L, Gonzalez-Cerrutti R, Barroso R, Carneiro F, Meijomil P. Family education, a model for allergy prevention [Spanish]. Investigacion Clinica 1996;37:221-45.

\section{Petro 1995}

Petro W, Hollander P, Hamann B, Lauber B, Mzyk C, Prittwitz M. Patientenschulung in der pneumologischen rehabilitation steigert den terapeutischen Erfolg. Atemwegs und Lungerkrankheiten 1995 Suppl;49-58.

\section{Premaratne 1999}

Premaratne UN, Sterne JAC, Marks GB, Webb R, Azima H, Burney PGJ. Clustered randomised trial of an intervention to improve the management of asthma: Greenwich asthma study. British Medical Journal 1999;318:1251-5.

Ringsberg 1990

Ringsberg KC, Wiklund I, Wilhelmsen L. Education of adult patients at an "asthma school": effects on quality of life, knowledge and need for nursing. European Respiratory Journal 1990;3:33-7.

\section{Rydman 1999}

Rydman RJ, Sonenthal K, Laksminarayana T, Butki N, McDermott, MF. Evaluating the outcome of two teaching methods of breath actuated inhaler in an inner city asthma clinic. Journal of Medical Systems 1999;23:349-56

\section{Sondergaard 1992} Sondergaard B, Davidsen F, Kirkeby B, Rasmussen M, Hey H. The economics of an intensive educational programme for asthmatic patients. A prospective controlled trial. Pharmacoeconomics 1992;3 $207-12$.

\section{Thapar 1994}

Thapar A. Educating asthmatic patients in primary care: a pilot study of small group education. Family Practice 1994;11:39-43.

\section{Tougaard 1992}

Tougaard L, Krone T, Sorknaes, Ellegaard H, PASTMA group. Economic benefits of teaching patients with chronic obstructive pulmonary disease about their asthma. Lancet 1992;339:1517-20. 
Turner 1998

Turner MO, Taylor D, Bennett R, Fitzgerald JM. A randomized trial comparing peak expiratory flow and symptom self-management plans for patients with asthma attending a primary care clinic. American Journal of Respiratory and Critical Care Medicine 1998;157:5406.

\section{Verver 1996}

Verver S, Poelman M, Bogels A, Chisholm SL, Dekker FW. Effects of instruction by practice assistance on inhaler technique and respiratory symptoms of patients. A controlled randomized videotaped intervention study. Family Practice 1996;13:35-40.

\section{White 1989}

White PT, Pharoah CA, Anderson HR, Freeling P. Randomised controlled trial of small group education on the outcome of chronic asthma in general practice. Journal of the Royal College of General Practitioners 1989;39:182-6.

\section{References to studies awaiting assessment}

Im 1993

Im J. Evaluation of effectiveness of an asthma clinic managed by an ambulatory care pharmacist. California Journal of Hospital Pharmacy 1993;5:5-6.

\section{References to ongoing studies}

\section{Ford 1996}

Ford ME, Edwards G, Rodrigues JL, Gibson RC, Tilley BC. An empowerment-centered, church-based asthma education program for African American adults. Health and Social Work 1996;21:70-5.

\section{Ploska 1999}

Ploska JF. Asthma education nurses in the hospital (French) [Infirmiere educatrice de l'asthme en secteur hospitalier]. Revue de l Infirmiere 1999;50:35-40.

\section{Additional references}

Anonymous 1992

Anonymous. International Consensus Report on Diagnosis and Treatment of Asthma. 1992.

\section{Anonymous 1996}

Annonymous. Asthma Management Handbook 1996.

\section{Bernard-Bonnin 1995}

Bernard-Bonnin A, et al.Self-management teaching programs and morbididty of pediatric asthma: a meta-analysis. Journal of Allergy \& Clinical Immunology 1995;95:23-41.

\section{Clark 1993}

Clark NM, Gotsch A, Rosenstoc IR. Patient, professional and public educationon behavioural aspects of asthma: a review of strategies for change and needed research. Journal of Asthma 1993;30:241-55.

\section{Gibson 1993a}

Gibson PG, et al.A prospective audit of asthma management following emergency asthma treatment at a teaching hospital. Medical Journal of Australia 1993;158:775-8.

\section{Gibson 1993b}

Gibson PG. Asthma guidelines and evidenced-based medicine. Lancet 1993;342:1305.

\section{Gibson 1998}

Gibson PG, Coughlan J, Wilson AJ, Hensley MJ, Abramson M, Bauman A, et al.The effects of limited (information-only) asthma education on health outcomes of adults with asthma (Cochrane Review). The Cochrane Library 1998, Issue 1.

\section{Peat 1994}

Peat JK, et al.Changing prevalence of asthma in Australian Children. British Medical Journal 1994;308:1591-6.

\section{Woolcock 1989}

Woolcock A, et al.Asthma Managment Plan. Medical Journal of Australia 1989;151:650-3.

*Indicates the major publication for the study

T A B LE S

\section{Characteristics of included studies}

\begin{tabular}{ll} 
Study & Abdulwadud 1999 \\
\hline Methods & DESIGN: Randomised controlled trial \\
& METHOD OF RANDOMISATION: Simple random number table. \\
& MEANS OF ALLOCATION CONCEALMENT- not concealed \\
& OUTCOME ASSESSOR BLINDING- none \\
& WITHDRAWAL/DROPOUTS - all participants accounted for. \\
\hline Participants & Eligible:175 \\
& Randomised: 125 (Intervention 64, Control 61) \\
& Completed: 77 (Intervention 30, Control 47) \\
& Age: Overall mean 46 yrs. Intervention 48 yrs, Control 43 yrs. \\
\hline
\end{tabular}




\section{Characteristics of included studies (Continued)}

\begin{tabular}{ll} 
& Range: 16 to 82 yrs \\
Sex: Male / Female: $50 / 75$ \\
Asthma Diagnosis: Doctor's diagnosis based on ATS criteria. \\
Recruitment: Hospital asthma \& allergy clinc. \\
Diseases Included: \\
Major Exclusions: Those with inadequate english skills, hearing or sight problems or asthma not their major \\
illness. \\
Baseline: $96 \%$ mod - severe asthma. \\
FEV1: Mean \% predicted: Intervention 54\%, Control 55\%. \\
PEF: Median PEF variability over 1 week 14.6\%. \\
Exacerbations: not stated. \\
\hline Setting: Hospital outpatients \\
Type: Basic asthma knowledge, physiology and triggers. Instruction on PEF self monitoring, and asthma \\
action plans - ? individualised. Understanding of medications and inhaler technique. \\
Duration: Three 90 minute group sessions over 3 weeks. \\
\hline Outcomes & Knowledge, Skills, quality of life,attitudes and beliefs. \\
\hline Notes & Jadad Score = 5 \\
\hline Allocation concealment & C - Inadequate \\
\hline
\end{tabular}

\section{Study}

Methods

\section{Allen 1995}

DESIGN: Randomised controlled trial stratified according to peak flow ownership.

METHOD OF RANDOMISATION: Randomised - stated. Method not described.

MEANS OF ALLOCATION CONCEALMENT- blinded.

OUTCOME ASSESSOR BLINDING - not stated.

WITHDRAWAL/DROPOUTS - all participants accounted for.

\begin{tabular}{|c|c|}
\hline Participants & $\begin{array}{l}\text { Eligible: } 116 \\
\text { Randomised: } 58 / 58 \\
\text { Completed: } 56 / 57 \\
\text { Age: Mean: } 40 \text { yrs Range: } 19 \text { to } 63 \\
\text { Sex: Male / Female } 46 \% / 54 \% \\
\text { Asthma Diagnosis: Doctors Diagnosis } \\
\text { Recruitment: volunteer community respondents } \\
\text { Diseases Included: Asthma - moderate to severe } \\
\text { Major exclusions: Current smokers or quit in the past } 3 \text { months, previous asthma education programme. } \\
\text { Baseline: } \\
\text { FEV1: Intervention } \mathrm{n}=56.16 \% \text { normal (> or }=80 \%), 77 \% \text { mild } / \text { moderate }(50 \text { to } 79 \%) \text { ), } 7 \% \text { severe }(< \\
\text { 50\%). Control } \mathrm{n}=57.10 \% \text { normal, } 78 \% \text { mild } / \mathrm{mod}, 12 \% \text { severe. } \\
\text { PEF: Intervention } \mathrm{n}=54 . \text { median } 58.4, \text { range } 35.0 \text { to } 77.0 \text {. Control } \mathrm{n}=26 \text {. median } 48.3 \text {, range } 37 \text { to } 75 \text {. } \\
\text { Exacerbations - not stated. }\end{array}$ \\
\hline Interventions & $\begin{array}{l}\text { Setting: Hospital Based community service asthma education programme } \\
\text { Type: Education, Self Monitoring of Peak Flow and External Regular Review. (diaries of medications and } \\
\text { symptoms were kept by members of both groups for } 4 \text { week periods at } 3,6,9 \text { and } 12 \text { months. If control } \\
\text { group members owned a PF, they recorded this also. All members of the intervention group recorded PF and } \\
\text { were taught in its use and interpretation). } \\
\text { Duration: weekly } 2.5 \text { hour group education sessions over } 4 \text { weeks (total } 10 \mathrm{hrs)}\end{array}$ \\
\hline Outcomes & $\begin{array}{l}\text { Knowledge, Compliance, scheduled and unscheduled doctor and hospital visits, disrupted days (ie being } \\
\text { confined to bed or a chair), Frequency of morning wheeze, nocturnal asthma symptoms, bronchodilator } \\
\text { medications, pre-bronchodilator FEV1/FVC, asthma symptoms diary, PEF. }\end{array}$ \\
\hline
\end{tabular}

Notes 


\section{Characteristics of included studies (Continued)}

Allocation concealment A-Adequate

\section{Study}

Methods
Bailey 1990

DESIGN: Randomised Controlled Trial. Stratified by 11 physicians and 3 asthma severity levels. Blocked so that 2 out of 4 in a given stratum were assigned to intervention and control.

METHOD OF RANDOMISATION: Separate randomisation schedule for the 33 strata were prepared in advance. Method of randomisation not stated.

METHOD OF CONCEALMENT: closed envelope technique.

OUTCOME ASSESSOR BLINDING: not stated.

WITDHRAWAL/DROPOUTS: all subjects accounted for.

Participants

Eligible: not stated

Randomised: 267 Intervention 132, Control 135

Completed: 225 Intervention 124, Control 101

Age: $<20$ yrs Int $1.6 \%$, Cont $5.1 \%$; $20-39$ yrs Int $27.4 \%$, Cont $31.6 \%$; $50-59$ yrs Int $37.1 \%$, Cont $30.6 \%$; $>l=60$ yrs Int $33.9 \%$, Cont $32.7 \%$.

Sex: Male / Female Intervention 39/61 Control 29/71.

Asthma Diagnosis: Doctor's diagnosis.

Recruitment: Regular Clinic Visits

Diseases Excluded: Another pulmonary or severly debilitation disease (eg CF, CA, severe rheumatoid arthritis.

Other exclusions: Under 18 years, refusal (5\%)

Baseline:

FEV1: not reported

PEF: not reported

Exacerbations: Intervention Mild 37.1\%, Mod 47.6\%, Severe 16.3\%; Control Mild 38.6\%, Moderate 44.6\%, Severe $16.8 \%$.

Interventions Setting: Outpatient clinic

Type: Education, peak flow self monitoring and regular review.

Duration: one hour, one to one session - Subjects were provided information about attack management but not an individualised written action plan.

Outcomes Skills, Hospitalisations, ER visits, Days off work/school, Compliance, Severity of asthma symptoms, bothered by asthma symptoms, 5 or more days coughing or dysponea.

Notes

Allocation concealment A-Adequate

Study

Bailey 1999

Methods

DESIGN: Randomised controlled trial of two interventions.

METHOD OF RANDOMISATION: Stratified by severity and blocked to ensure 2 of every 6 participants were assigned in each group

MEANS OF ALLOCATION CONCEALMENT- Closed envelope technique

OUTCOME ASSESSOR BLINDING- Blinded

WITHDRAWAL/DROPOUTS- 7\% attrition rate. All participants not accounted for.

Participants

Eligible: Not stated

Randomised: 236

Completed: 221

Age: Mean: not stated

Range: $94(41 \%)<40 \mathrm{yrs}, 138(59 \%)>=40 \mathrm{yrs}$

Sex: Male/Female: $71 / 161$

Asthma Diagnosis: Doctor diagnosis and objective lung function.

Recruitment: Pulmonary clinc visit 


\section{Characteristics of included studies (Continued)}

\begin{tabular}{|c|c|}
\hline & $\begin{array}{l}\text { Diseases Included: Not stated. } \\
\text { Major Exclusions: Not stated. } \\
\text { Baseline: } \\
\text { FEV1: not reported } \\
\text { PEF: not reported } \\
\text { Exacerbations: moderate to severe asthmatics }\end{array}$ \\
\hline Interventions & $\begin{array}{l}\text { Setting:Outpatients clinc } \\
\text { Type: Two self management interventions, one modified, and a usual care control group. } \\
\text { (1) Counselling re use of skill-oriented self help work book including info on asyhma physiology, medications, } \\
\text { trigger avoidance detection, response to asthma attacks and inhaler technique. No individualised action plan. } \\
\text { (2) Instruction of use of a modified work book, inhaler technique and peak flow meter use. } \\
\text { (3) control group received usual care and some asthma literature. } \\
\text { Duration: } \\
\text { (a) One } 1 \text { hour individual session and } 2 \text { asthma support group meetings. } \\
\text { (b) One } 15 \text { minute individual session plus a } 1 \text { week followup phone call and at } 2 \text { weeks a letter to encourage } \\
\text { adherence. }\end{array}$ \\
\hline Outcomes & $\begin{array}{l}\text { Medication \& inhaler adherence, symptoms, respiratory illness, functional impairment \& use of health care } \\
\text { services. }\end{array}$ \\
\hline Notes & Jadad Score $=4$ \\
\hline Allocation concealment & A - Adequate \\
\hline Study & Berg 1997 \\
\hline Methods & $\begin{array}{l}\text { DESIGN: Randomised Controlled Trial } \\
\text { METHOD OF RANDOMISATION: the word "random" stated ; stratified according to severity (moder- } \\
\text { ate/severe) } \\
\text { METHOD OF ALLOCATION CONCEALMENT: not described. } \\
\text { OUTCOME ASSESSOR BLINDING: not stated. } \\
\text { WITHDRAWAL/DROPOUTS: all subjects accounted for. }\end{array}$ \\
\hline Participants & $\begin{array}{l}\text { Eligible: } 68 \\
\text { Randomised: } 55 \\
\text { Completed: } 54 \text { (Intervention 31; Control 24) } \\
\text { Age: Overall mean: } 50 \text { yrs (sd 16) } \\
\text { Sex: Male / Female 19/36 } \\
\text { Asthma Diagnosis: Doctor's diagnosis } \\
\text { Recruitment: Rural community } \\
\text { Diseases Included: not specified - but smokers were included } \\
\text { Major exclusions: Not specified } \\
\text { Baseline: } \\
\text { FEV1: Patients described their asthma as moderate to severe. } \\
\text { PEF: am intervention } 360 \text { (sd 105); control } 365 \text { (sd 137) } \\
\text { pm intervention } 347 \text { (sd 107); control } 371 \text { (sd 140) } \\
\text { Exacerbations: not stated }\end{array}$ \\
\hline Interventions & $\begin{array}{l}\text { Setting: community based education program } \\
\text { Type: Small group education and self monitoring of peak flow and symptoms. } \\
\text { Control: No special education. Controls kept an asthma diary (symptoms and PEF) for one week at baseline } \\
\text { and one week at the end of the study for outcome assessment. } \\
\text { Duration: } 6 \text { x } 2 \text { hour training sessions ie } 1 / \text { week over } 6 \text { weeks. }\end{array}$ \\
\hline Outcomes & Compliance, symptoms, am PEFR, pm PEFR, Asthma self-efficacy, Asthma self-management. \\
\hline \multicolumn{2}{|l|}{ Notes } \\
\hline Allocation concealment & B - Unclear \\
\hline
\end{tabular}




\section{Characteristics of included studies (Continued)}

\begin{tabular}{|c|c|}
\hline Study & Blixen 2001 \\
\hline Methods & $\begin{array}{l}\text { DESIGN: Randomised Controlled Trial } \\
\text { METHOD OF RANDOMISATION: Not stated } \\
\text { MEANS OF ALLOCATION CONCEALMENT- Not stated } \\
\text { OUTCOME ASSESSOR BLINDING- blinded } \\
\text { WITHDRAWAL/DROPOUTS- all participants accounted for }\end{array}$ \\
\hline Participants & $\begin{array}{l}\text { Eligible: } 40 \\
\text { Randomised: } 28 \text { (14/14) } \\
\text { Completed: } 13 \text { (Intervention 7, Control 6) } \\
\text { Age: Mean overall: } 36 \text { yrs Range: } 18 \text { to } 50 \\
\text { Sex: Male/Female: } 7 / 20 \\
\text { Asthma Diagnosis: Doctor diagnosis } \\
\text { Recruitment: Hospital admissions } \\
\text { Diseases Included: Not stated } \\
\text { Major Exclusions: not stated } \\
\text { Baseline: } 54 \% \text { asthma > } 10 y r s \\
\text { FEV1: } \\
\text { PEF: } \\
\text { Exacerbations: In previous } 2 \text { weeks } 57 \% \text { had mild intermittent or persistent asthma, } 32 \% \text { moderate persistent } \\
\& 11 \% \text { severe asthma }\end{array}$ \\
\hline Interventions & $\begin{array}{l}\text { Setting: Hospital } \\
\text { Type: Individual sessions while an inpatient covering rationale and skills of asthma self management, explana- } \\
\text { tion of "asthma self management workbook" and self monitoring techniques. Video on peak flow monitoring } \\
\text { and written reinforcement materials sent at } 3 \text { and } 6 \text { months. } \\
\text { Duration:Three 1hour sessions }\end{array}$ \\
\hline Outcomes & Hospitalisation, aer visits, unscheduled Dr visits, quality of life and depression scale \\
\hline Notes & Jadad Score $=3$ \\
\hline Allocation concealment & B - Unclear \\
\hline
\end{tabular}

\section{Study}

Methods

\section{Brewin 1995}

DESIGN: not randomised - all participants for intervention group were admitted to Pembury Hospital. METHOD OF ALLOCATION CONCEALMENT: Inadequate. Participants for the "control group" were allocated systematically according to a pre-set hospital rotation.

OUTCOME ASSESSOR BLINDING: implied but unclear. WITHDRAWAL/DROPOUTS: No dropouts.

\begin{tabular}{ll}
\hline Participants & Eligible: ? \\
& Randomised 83 \\
& Completed: 45 Intervention 33; Control 12. \\
& Age: Overall mean: N/S Range: N/S \\
& Sex: Male / Female - N/S \\
& Asthma Diagnosis: Doctor's Diagnosis \\
& Recruitment: Patients admitted to hospital for asthma \\
& Diseases Included: N/S \\
& Major exclusions: N/S \\
& Baseline: \\
& FEV1: N/S \\
& PEF: N/S \\
& Exacerbations: N/S \\
Setting: inpatient & Type: one to one sessions with a respiratory nurse, peak flow self monitoring.
\end{tabular}


Characteristics of included studies (Continued)

\begin{tabular}{|c|c|}
\hline & Duration: at least 30 minutes \\
\hline Outcomes & Knowledge, symptoms, days off work, nocturnal waking, need for and frequency of bronchodilator use. \\
\hline \multicolumn{2}{|l|}{ Notes } \\
\hline Allocation concealment & $\mathrm{C}$ - Inadequate \\
\hline Study & Cote 1997 \\
\hline Methods & $\begin{array}{l}\text { DESIGN: Randomised controlled trial of two interventions } \\
\text { METHOD OF RANDOMISATION: Randomised - stratified randomisation } \\
\text { MEANS OF ALLOCATION CONCEALMENT- not stated. } \\
\text { OUTCOME ASSESSOR BLINDING - not blinded. } \\
\text { WITHDRAWAL/DROPOUTS - all subjects accounted for. }\end{array}$ \\
\hline Participants & $\begin{array}{l}\text { Eligible: not specified } \\
\text { Randomised: } 188 \text { (Peak Flow 62, Symptoms Only 52, Control 74) } \\
\text { Completed: } 149 \text { (Peak Flow 50, Symptoms Only 45, Control 54) } \\
\text { Age: Overall mean: } 36 \text { yrs Range: } \\
\text { Sex: Male/Female - } \\
\text { Asthma Diagnosis: Doctor's diagnosis and objective lung function } \\
\text { Recruitment: Hospital admissions or visit to a clinic. } \\
\text { Diseases Included: } \\
\text { Major exclusions: current and ex-smokers } 40 \text { yr of age or older in whom the best FEV1 after salbutamol was } \\
<80 \% \text { of predicted, patients with significant concurrent diseases, those requiring > } 7.5 \text { mg prednisone to } \\
\text { control asthma symptoms and those who had already taken part in an asthma education program. } \\
\text { Baseline: } \\
\text { FEV1: not stated } \\
\text { PEF: \% predicted: Peak Flow 93+/-3; Symptoms } 91+/-3 \text {; Control } 95+/-3 \text {. } \\
\text { Exacerbations not stated }\end{array}$ \\
\hline Interventions & $\begin{array}{l}\text { Setting: tertiary care setting } \\
\text { Type: Two optimal interventions and an active control. } \\
\text { (1) Education, peak flow self monitoring, regular review and individualised written action plan based on } \\
\text { peak flow enabling self adjustment of medications in the event of worsening asthma. } \\
\text { (2) Education, symptoms self monitoring, regular review and a symptoms based written action plan enabling } \\
\text { self adjustment of medications in the event of worsening asthma. } \\
\text { (3) Control group: Taught inhaler technique by the educator and about medication use and triggers by their } \\
\text { pulmonologist. Their physician may have provided a verbal action plan. } \\
\text { Duration: A minimum of } 1 \mathrm{x} \text { one hour one to one counselling sessions for both educated groups }\end{array}$ \\
\hline Outcomes & Knowledge, compliance, hospitalisations, ER visits, oral corticosteroids, days lost from work or school. \\
\hline Notes & $\begin{array}{l}\text { Jadad Score }=4 \\
\text { Treatment was optimised for all subjects during baseline. }\end{array}$ \\
\hline Allocation concealment & B - Unclear \\
\hline
\end{tabular}

\begin{tabular}{ll} 
Study & Cowie $\mathbf{1 9 9 7}$ \\
\hline Methods & DESIGN: Randomised controlled trial of two interventions \\
& METHOD OF RANDOMISATION: Random numbers list \\
& MEANS OF ALLOCATION CONCEALMENT- sequentially administered identical opaque closed enve- \\
& lope technique \\
& OUTCOME ASSESSOR BLINDING - outcome assessors blinded \\
& WITHDRAWAL/DROPOUTS - all subjects accounted for. \\
\hline
\end{tabular}

\begin{tabular}{ll}
\hline Participants & Eligible: not specified \\
& Randomised: 151 (one withdrawn: not asthma)
\end{tabular}




\section{Characteristics of included studies (Continued)}

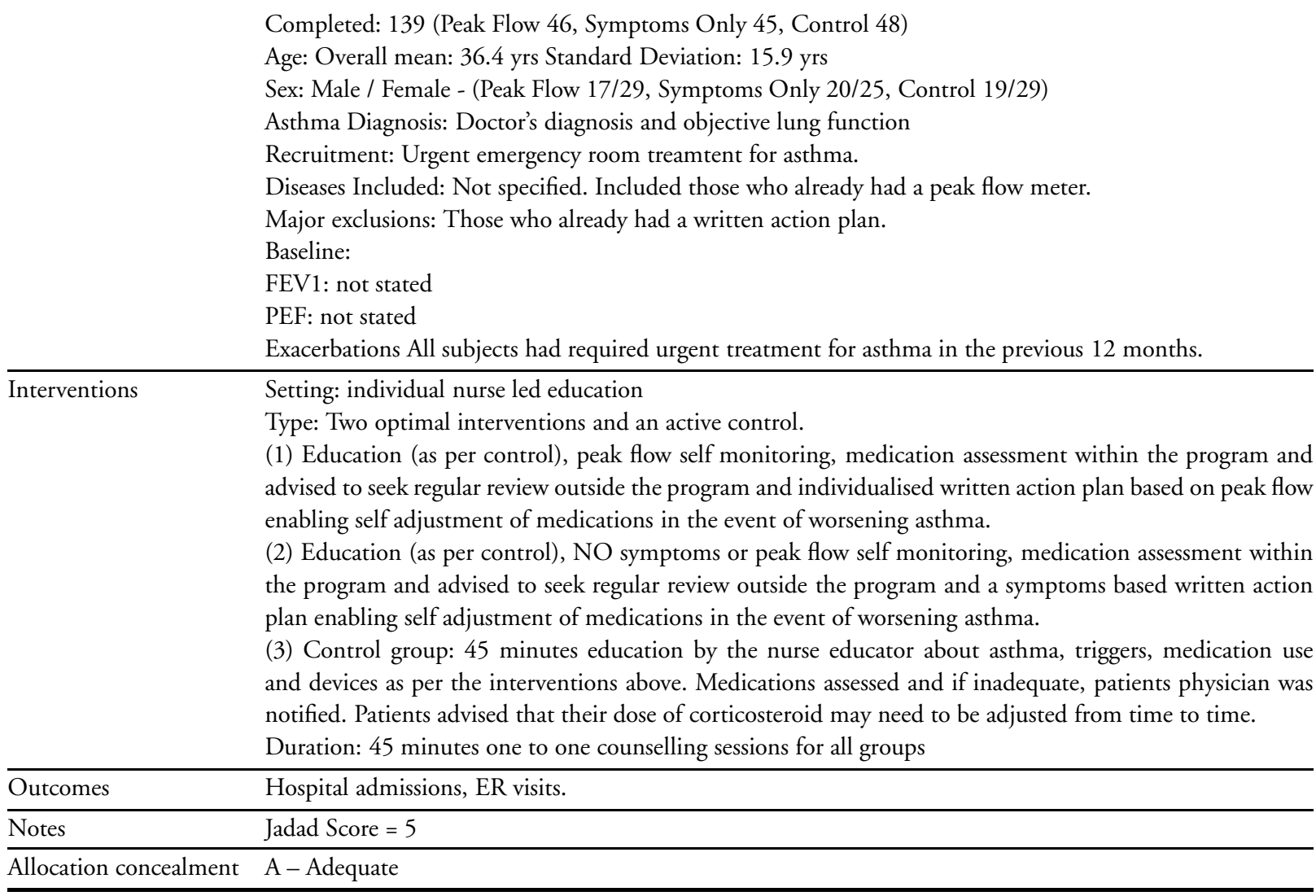

\begin{tabular}{|c|c|}
\hline Study & Gallefoss 1999 \\
\hline Methods & $\begin{array}{l}\text { DESIGN: Randomised Controlled Trial. } \\
\text { METHOD OF RANDOMISATION: Randomised - stated. Method not described. } \\
\text { MEANS OF ALLOCATION CONCEALMENT- Not stated. } \\
\text { OUTCOME ASSESSOR BLINDING- for spirometry, ? for other outcomes. } \\
\text { WITHDRAWAL/DROPOUTS- All subjects accounted for. }\end{array}$ \\
\hline Participants & $\begin{array}{l}\text { Eligible: } 85 \\
\text { Randomised: } 78 \text { (Intervention 39, Control 39) } \\
\text { Completed: } 71 \text { (Intervention 32, Control 39). } \\
\text { Age: mean overall: } 45 \text { yrs. Intervention 44, Control } 41 \\
\text { Range: } 18 \text { to } 70 \text { yrs eligible. } \\
\text { Sex: Male/Female: } 23 / 55 \\
\text { Asthma Diagnosis: Objective lung function. } \\
\text { Recruitment: Outpatients clinic. } \\
\text { Diseases Included: } \\
\text { Major Exclusions: Unstable CHD, heart failure, hypertension, diabetes, kidney or liver failure. } \\
\text { Baseline: } \\
\text { FEV1: > } 80 \% \text { predicted. } \\
\text { PEF: } \\
\text { Exacerbations: mild to moderate asthma. }\end{array}$ \\
\hline Interventions & $\begin{array}{l}\text { Setting: Outpatients clinic } \\
\text { Type: Basic introduction to asthma, anatomy and physiology, prevention \& triggers, pharmacology of asthma } \\
\text { drugs. Subjects received a } 19 \text { page booklet including self-care and self-management plan. Instructions on } \\
\text { PEF and symptom self-monitoring. Patients received an individual treatment plan. }\end{array}$ \\
\hline
\end{tabular}




\section{Characteristics of included studies (Continued)}

Controls followed by their GP.

Duration: Two 2 hour group sesions on two separate days with a Doctor and pharmacist followed by 1-2 individual sessions with a nurse and 1-2 individual sessions with a physiotherapist.

\begin{tabular}{ll}
\hline Outcomes & $\begin{array}{l}\text { FEV1, quality of life, rescue medications, compliance, hospitalisations, unscheduled Dr visits, days off work, } \\
\text { costs, patient satisfaction }\end{array}$ \\
\hline Notes & Jadad Score $=4$ \\
\hline Allocation concealment & B - Unclear \\
\hline
\end{tabular}

\begin{tabular}{|c|c|}
\hline Study & Garret 1994 \\
\hline Methods & $\begin{array}{l}\text { DESIGN: Randomised Controlled Trial. } \\
\text { METHOD OF RANDOMISATION: randomised. } \\
\text { METHOD OF ALLOCATION CONCEALMENT: closed envelope technique. } \\
\text { OUTCOME ASSESSOR BLINDING: outcome assessors were blinded. } \\
\text { WITHDRAWAL/DROPOUTS: all subjects accounted for. }\end{array}$ \\
\hline Participants & $\begin{array}{l}\text { Eligible: } 980 \\
\text { Randomised: 500: Intervention 251; Control } 249 . \\
\text { Completed: } 451 \\
\text { Age: } 2-5 \text { years: Intervention 25\% Control 26\%. 6-14 years:Intervention 19\% Control 21\%. 15-29 years } \\
\text { Intervention 30\% Control 32\%. 30-55 years: Intervention 25\% Control 21\%. } \\
\text { Sex: Male / Female Intervention 38/62\% Control 46/54\% } \\
\text { Asthma Diagnosis: Doctor's diagnosis } \\
\text { Recruitment: Emergency Room Attenders (whether hospitalisation was required or not) } \\
\text { Diseases Included: not stated } \\
\text { Major exclusions: not stated } \\
\text { Baseline: } \\
\text { FEV1: not stated } \\
\text { PEF: not stated } \\
\text { Exacerbations: not stated }\end{array}$ \\
\hline Interventions & $\begin{array}{l}\text { Setting: Community Education Centre. } \\
\text { Type: Education, self-monitoring of symptoms and peak flow, regular review (advised to seek regular review } \\
\text { from their GP). } \\
\text { Participants were advised to obtain a written action plan from their GP which allowed self adjustment of } \\
\text { medications in the event of worsening asthma but as this was not a part of the intervention, it was not } \\
\text { characterised as Optimal Self Management but Self Monitoring and Regular Review. } \\
\text { Duration: Not stated }\end{array}$ \\
\hline Outcomes & $\begin{array}{l}\text { Hospital admissions, ER visits, Unscheduled doctor visits, days lost from work or school, nocturnal awak- } \\
\text { ening, asthma status (same worse better), PEF variability, Symptoms, dysponea on exercise. }\end{array}$ \\
\hline
\end{tabular}

Notes

Only about $60 \%$ of data refers to adults.

Allocation concealment A-Adequate

\begin{tabular}{ll} 
Study & George $\mathbf{1 9 9 9}$ \\
\hline Methods & DESIGN: Randomised Controlled Trial \\
& METHOD OF RANDOMISATION: random number generation \\
& MEANS OF ALLOCATION CONCEALMENT- Not stated \\
& OUTCOME ASSESSOR BLINDING- Not stated \\
& WITHDRAWAL/DROPOUTS- all participantts accounted for. \\
\hline Participants & Eligible: 88 \\
\hline
\end{tabular}

Self-management education and regular practitioner review for adults with asthma (Review)

Copyright ( 2008 The Cochrane Collaboration. Published by John Wiley \& Sons, Ltd 


\section{Characteristics of included studies (Continued)}

\begin{tabular}{l} 
Randomised: 77 (Intervention 44, Control 33) \\
Completed: 77 (44/33) \\
Age: Overall Mean: 29 yrs, Intevention 29yrs, Control 29yrs. Range: 18 to 45 yrs \\
Sex: Male/Female: 16/61 \\
Asthma Diagnosis: Doctor diagnosis on admission \\
Recruitment: Hospital admissions \\
Diseases Included: N/S \\
Major Exclusions: comorbid disease, non-english speaking, no home telephone, pregnancy, intensive care \\
admission. \\
Baseline: \\
FEV1: not reported \\
PEF: not reported \\
Exacerbations: enrolled on acute admission to hospital \\
Setting: In hospital \\
Type: Asthma instruction, inhaler technique, early warning signs, and action plans for appropriate responses. \\
Importance of regular followup stressed. \\
Controls received routine care. Education at “discretion of staff” \\
Duration: repetitive sessions while in hospital and 7 day followup in outpatients \\
\hline Hospitalisation, ER visits, length of hospital stay, outpatient visits. \\
\hline Outcomes \\
\hline Notes \\
\hline Allocation concealment Score = 5 \\
\hline B - Unclear
\end{tabular}

\begin{tabular}{|c|c|}
\hline Study & Ghosh 1998 \\
\hline Methods & $\begin{array}{l}\text { DESIGN: Randomised Controlled Trial } \\
\text { METHOD OF RANDOMISATION: Not stated } \\
\text { MEANS OF ALLOCATION CONCEALMENT- Not stated. } \\
\text { OUTCOME ASSESSOR BLINDING- Not stated } \\
\text { WITHDRAWAL/DROPOUTS- all subjects accounted for }\end{array}$ \\
\hline Participants & $\begin{array}{l}\text { Eligible: Not stated } \\
\text { Randomised: } 303 \text { (Intervention 153, Control 150) } \\
\text { Completed: } 276 \text { (Intervention 140, Control 136). } \\
\text { Age: } 10 \text { to } 19 \text { yrs Int. } 27 \% \text {, Cont. } 33 \%, 20 \text { to } 29 \mathrm{yrs} \mathrm{Int.} 23 \% \text { Cont } 18 \%, 30 \text { to } 39 \text { yrs Int } 29 \% \text {, Cont } 31 \% \text {, } \\
40 \text { to } 45 \text { yrs Int } 21 \% \text { Cont } 18 \% \text {. Range: } 10 \text { to } 45 \text { yrs } \\
\text { Sex: Male/Female: } 113 / 163 \\
\text { Asthma Diagnosis: Doctor diagnosis and objective lung function. } \\
\text { Recruitment: Asthma \& Allergy Clinic } \\
\text { Diseases Included: not stated } \\
\text { Major Exclusions: chronic respiratory infections, bronchitis, emphysema, multisystem disorders, history of } \\
\text { smoking. } \\
\text { Baseline: } \\
\text { FEV1: }>15 \% \text { reversibility } \\
\text { PEF: Mean (SD) Int } 281(65) \text {, Cont } 274(67) \\
\text { Exacerbations: at least one admission or ER visit in past } 12 \text { months. drug therapy at least } 50 \% \text { of the days } \\
\text { in a month }\end{array}$ \\
\hline Interventions & $\begin{array}{l}\text { Setting: outpatients clinic } \\
\text { Type: Asthma self-management training in first month following baseline interview. Audiovisual aides used to } \\
\text { highlight preventative measures, detailed teaching of PEFR and significance of variation. Individual written } \\
\text { action plan. Self monitoring for } 4 \text { single months. Medically assessed and treatment adjusted at baseline. } \\
\text { Controls kept } 4 \text { x } 1 \text { month diaries and medically assessed at baseline. No education given } \\
\text { Duration: } 4 \text { x } 2 \text { hour sessions }\end{array}$ \\
\hline
\end{tabular}


Characteristics of included studies (Continued)

\begin{tabular}{|c|c|}
\hline Outcomes & Hospitalisations, ER visits, PEF, Days off work, costs. \\
\hline \multirow[t]{2}{*}{ Notes } & Jadad Score $=4$ \\
\hline & Intervention $27 \% 10$ to 19 yrs age, Control $33 \%$ \\
\hline Allocation concealment & B - Unclear \\
\hline Study & Grampian 1994 \\
\hline Methods & $\begin{array}{l}\text { DESIGN: } 2 \times 2 \times 2 \text { block randomised trial stratified by physician. } \\
\text { METHOD OF RANDOMISATION: the word "random" stated ; method not described. } \\
\text { METHOD OF ALLOCATION CONCEALMENT: not described. } \\
\text { OUTCOME ASSESSOR BLINDING: not stated. } \\
\text { WITHDRAWAL/DROPOUTS: dropouts }(6 \%) \text { not accounted for. }\end{array}$ \\
\hline Participants & $\begin{array}{l}\text { Eligible: } 801 \text { consented but } 232 \text { already had peak flow meter and could not be randomised for this arm. } \\
\text { Randomised: } 569 \text { : Peak flow self monitoring 285, Conventional monitoring } 284 \\
\text { Completed: } 458 \text { : Peak flow self monitoring } 230 \text {, Conventional monitoring } 228 . \\
\text { Age: Mean Intervention } 51.1 \text { yrs Control } 50.5 \text { years Range: > } 16 \text { years. } \\
\text { Sex: Male/Female Intervention 48/52\% Control 40/60\% } \\
\text { Asthma Diagnosis: Doctor's diagnosis and objective lung function } \\
\text { Recruitment: Hospital outpatient clinics and general practices in north east Scotland. } \\
\text { Diseases Included: N/S } \\
\text { Major exclusions: N/S } \\
\text { Baseline: } \\
\text { FEV1: \% of predicted: Intervention } 77.3 \% \text {; Control } 78.1 \% \\
\text { PEF: Mean: Intervention 344.5; Control 341.6. } \\
\text { Exacerbations: N/S }\end{array}$ \\
\hline Interventions & $\begin{array}{l}\text { Setting: } \\
\text { Type: education, self monitoring of peak flow, and regular review and written action plan to enable self } \\
\text { adjustment of medications in response to worsening asthma based on peak flow. (due to the factorial design, } \\
\text { some of the intervention group were randomised to receive enhanced education while the others had conven- } \\
\text { tional education. Similarly, some were randomised to receive integrated care while others had conventional } \\
\text { care). } \\
\text { Control: Some had enhanced education but none had peak flow meters. } \\
\text { Duration: not stated }\end{array}$ \\
\hline Outcomes & $\begin{array}{l}\text { Hospitalisation, unscheduled doctor visits, FEV1 \% predicted, use of rescue medication, quality of life, days } \\
\text { off work, inhaled steroids, disrupted days, nocturnal asthma. }\end{array}$ \\
\hline \multirow[t]{2}{*}{ Notes } & Jadad Score $=3$ \\
\hline & Confounding due to factorial design. \\
\hline Allocation concealment & B - Unclear \\
\hline
\end{tabular}

\begin{tabular}{ll} 
Study & Hayward $\mathbf{1 9 9 6}$ \\
\hline Methods & DESIGN: Randomised Controlled Trial \\
& METHOD OF RANDOMISATION: Random stated, method not described \\
& METHOD OF ALLOCATION CONCEALMENT: not stated \\
& OUTCOME ASSESSOR BLINDING: not stated. \\
& WITHDRAWAL/DROPOUTS: \\
\hline Participants & Eligible: 84 \\
& Randomised: 44( Intervention 23, Control 21) \\
& Completed: 42 (Intervention 23, Control 19) \\
& Age: Mean Intervention 51.1 Range: 6 to 74 yrs \\
& Sex: Male/Female \\
\hline
\end{tabular}




\section{Characteristics of included studies (Continued)}

\begin{tabular}{|c|c|}
\hline & $\begin{array}{l}\text { Asthma Diagnosis: not stated } \\
\text { Recruitment: GP } \\
\text { Diseases Included: N/S } \\
\text { Major exclusions: N/S } \\
\text { Baseline: } \\
\text { FEV1: } \\
\text { PEF: Mean: } \\
\text { Exacerbations: }\end{array}$ \\
\hline Interventions & $\begin{array}{l}\text { Setting: ? GP clinic } \\
\text { Type: Training from an asthma nurse specialist by telephone or attending a clinc monthly for } 1 \text { year. Education } \\
\text { in knowledge, triggers, symptoms, reliever vs preventer medication and inhaler technique. Written support } \\
\text { materials given. peak flow self monitoring and action plan - ? written. } \\
\text { Duration:Monthly clinic visit or telephone call for } 12 \text { months }\end{array}$ \\
\hline Outcomes & $\begin{array}{l}\text { Knowledge, hospitalisation, unscheduled Dr visits, rescue medication, days off work or school, exacerbations, } \\
\text { symptom score, symptoms }\end{array}$ \\
\hline Notes & $\begin{array}{l}\text { Jadad Score }=3 \\
\text { Includes children }\end{array}$ \\
\hline Allocation concealment & B - Unclear \\
\hline Study & Heard 1999 \\
\hline Methods & $\begin{array}{l}\text { DESIGN: Randomised Controlled Trial. } \\
\text { METHOD OF RANDOMISATION: Randomised - stated. Method not described } \\
\text { MEANS OF ALLOCATION CONCEALMENT- not concealed- randomisation chart for each practice. } \\
\text { OUTCOME ASSESSOR BLINDING- None } \\
\text { WITHDRAWAL/DROPOUTS - All subjects accounted for. }\end{array}$ \\
\hline Participants & $\begin{array}{l}\text { Eligible: Not stated } \\
\text { Randomised: } 195 \text { (Intervention 98, Control 97) } \\
\text { Completed: } 191 \text { (Intervention 97, Control 94). } \\
\text { Age: Mean Intervetion } 27.5 \text { yrs, Control } 26.3 \text { yrs. } \\
\text { Range: eligible } 5 \text { to } 64 \text { yrs } \\
\text { Sex: Male/Female: } \\
\text { Asthma Diagnosis: } \\
\text { Recruitment: } 8 \text { General Practices } \\
\text { Diseases Included: } \\
\text { Major Exclusions: } \\
\text { Baseline: } \\
\text { FEV1: } \\
\text { PEF: } \\
\text { Exacerbations: }\end{array}$ \\
\hline Interventions & $\begin{array}{l}\text { Setting: GP Asthma Clinic } \\
\text { Type: Nurse counselling, asthma management strategies, spirometry, peak flow and inhaler use. Explanation } \\
\text { of diary card use for PEF self monitoring and written action plan. Assessed by GP at end of each clinic } \\
\text { session. } \\
\text { Controls received standard medical treatment } \\
\text { Duration: } 3 \times 3 \text { hour sessions over } 6 \text { months }\end{array}$ \\
\hline Outcomes & $\begin{array}{l}\text { Knowledge, hospitalisation, ER visits, unscheduled Dr visits, preventer medication, days off work, productive } \\
\text { days lost, nocturnal asthma, use of action plan, owning a peak flow meter, smoking status, morning asthma } \\
\text { symptoms }\end{array}$ \\
\hline Notes & Jadad Score $=3$ \\
\hline
\end{tabular}




\section{Characteristics of included studies (Continued)}

Includes children

Allocation concealment $\mathrm{B}$ - Unclear

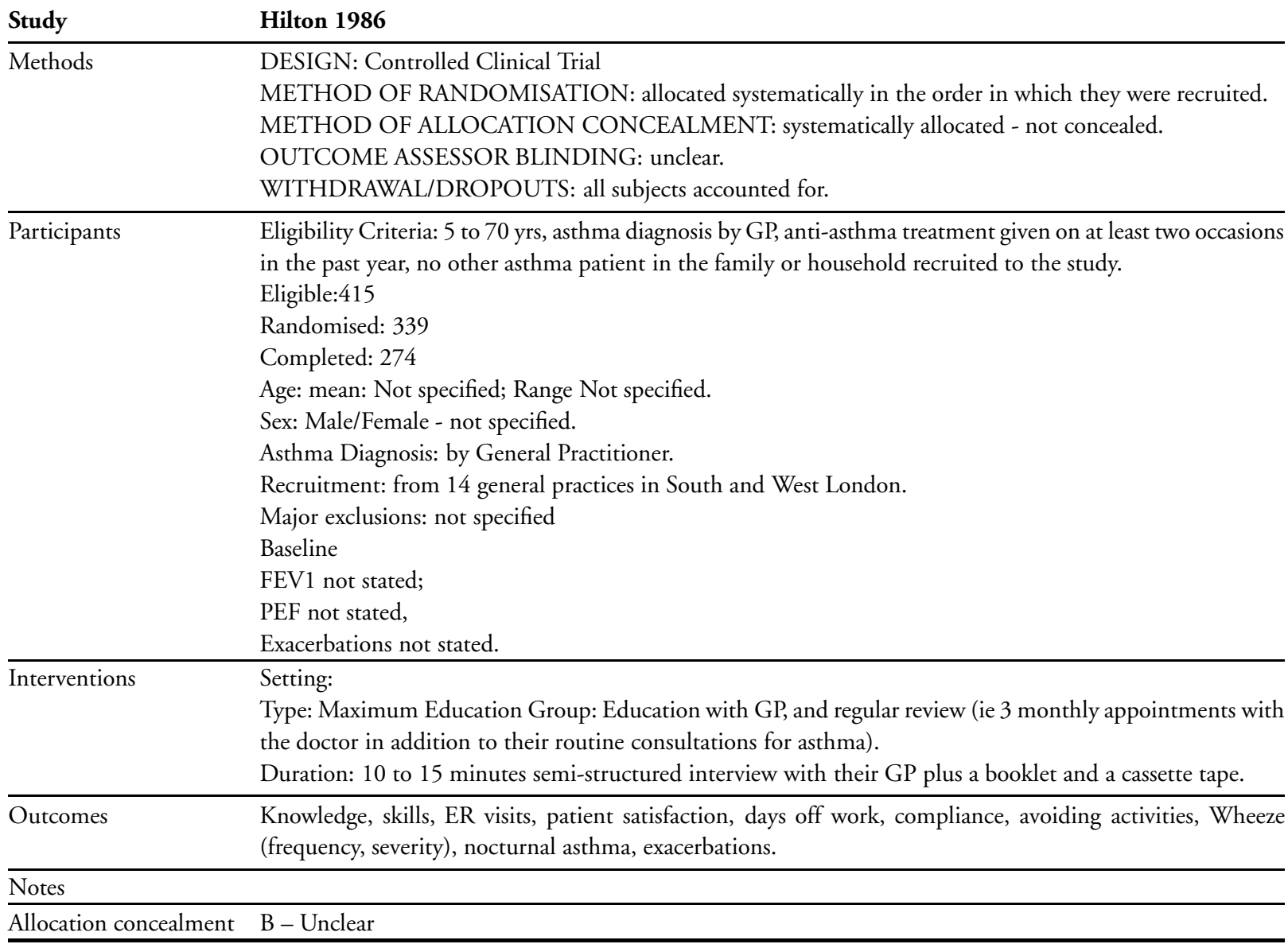

Study

Methods
Ignacio-Garcia 1995

DESIGN: Randomised Controlled trial

METHOD OF RANDOMISATION: the word "random" stated; "randomly allocated in the order in which they were recruited" by alternation.

METHOD OF ALLOCATION CONCEALMENT: alternation, not concealed.

OUTCOME ASSESSOR BLINDING: outcome assessor of intervention group not blinded; outcome assessor of control group was "blinded with regard to registers of peak flow monitoring until the end of the study".

WITHDRAWAL/DROPOUTS: all participants accounted for.
Eligible: not stated.

Randomised: 94 (Intervention 50, Control 44)

Completed: 70 (Intervention 35, Control 35) but a further 11 in Intervention group and 5 in control group were excluded at 3 months due to poor inhalation technique, lack of PEF monitoring \& non compliance with prescribed medication regimens leaving 54 (Intervention 24, Control 30).

Age: Overall mean: 42 Years Range: 16 to 64 years.

Sex: Male/Female $32 / 38$ of the study population of 70 .

Asthma Diagnosis: Doctor's diagnosis.

Recruitment: Outpatient asthma clinic 


\section{Characteristics of included studies (Continued)}

\begin{tabular}{|c|c|}
\hline & $\begin{array}{l}\text { Diseases Included: not specified } \\
\text { Major exclusions: not specified } \\
\text { Baseline: } \\
\text { FEV1: \% of predicted (Intervention } 69.03 \text { Control 65.34) } \\
\text { PEF: not stated } \\
\text { Exacerbations: not stated }\end{array}$ \\
\hline Interventions & $\begin{array}{l}\text { Setting: } \\
\text { Type: Optimal self management including education, peak flow self monitoring, regular review and a written } \\
\text { action plan based on peak flow which enabled self adjustment of medications in the event of worsening } \\
\text { asthma. } \\
\text { Control group: Self monitoring of symptoms and regular review. Collected PEF as an outcome but based } \\
\text { their treatment on physicians advice. } \\
\text { Duration: not stated. Study period was } 7 \text { months. }\end{array}$ \\
\hline Outcomes & $\begin{array}{l}\text { Hospitalisation, ER visits, doctor visits, lung function - \% predicted, use of rescue medication, days off work, } \\
\text { antibiotic therapy, nocturnal asthma, exacerbations, PEF - mean daily peak flow rate. }\end{array}$ \\
\hline \multicolumn{2}{|l|}{ Notes } \\
\hline Allocation concealment & $\mathrm{C}$ - Inadequate \\
\hline Study & Jones 1995 \\
\hline Methods & $\begin{array}{l}\text { DESIGN: Randomised Controlled Trial. Stratified by centre in blocks of six. } \\
\text { METHOD OF RANDOMISATION: the word "random" stated ; method not described. } \\
\text { METHOD OF ALLOCATION CONCEALMENT: not described. } \\
\text { OUTCOME ASSESSOR BLINDING: not clear - "data rendered anonymous" before analysis. } \\
\text { WITHDRAWAL/DROPOUTS: not described. }\end{array}$ \\
\hline Participants & $\begin{array}{l}\text { Eligible: not stated } \\
\text { Randomised: } 127 \\
\text { Completed: } 72 \text { (Intervention self management 33; planned visits 39) } \\
\text { Age: self managed : mean } 30.4 \text { yrs SD } 11.5 \text { yrs planned visits: mean } 28.6 \text { SD } 7 \text { yrs. } \\
\text { Sex: Male/Female Self managed } 14 / 19 \text { planned visits } 12 / 26 . \\
\text { Asthma Diagnosis: Doctor's diagnosis } \\
\text { Recruitment: General practices } \\
\text { Diseases Included: Not specified } \\
\text { Major exclusions: Those on regular oral steroids and those who were regularly conducting home PEF mon- } \\
\text { itoring. } \\
\text { Baseline: } \\
\text { FEV1: \% predicted: self management } 85.1 \text { (sd 20.8), planned visits } 80.2 \text { (sd19.9) } \\
\text { PEF: \% predicted: self management } 88.2 \text { (sd 15.4), planned visits } 86.8 \text { (sd 13.7) } \\
\text { Exacerbations }\end{array}$ \\
\hline Interventions & $\begin{array}{l}\text { Setting: General Practice } \\
\text { Type: Optimal self management: education, peak flow self monitoring, regular review and an individualised } \\
\text { written action plan based on peak flow enabling self adjustment of medications in the event of worsening } \\
\text { asthma. } \\
\text { Control: regular review and kept a daily diary for morbidity and bronchodilator use for outcomes. } \\
\text { Duration: }\end{array}$ \\
\hline Outcomes & $\begin{array}{l}\text { Lung Function - \% predicted, Use of rescue medication, quality of life, days off work, wheeze (frequency, } \\
\text { severity), nocturnal asthma, oral corticosteroid use, cough, shortness of breath, disrupted days. }\end{array}$ \\
\hline
\end{tabular}

Notes Jadad Score $=4$

Oral corticosteroids was given for 2 weeks to optimise lung function in both groups during baseline. Drop outs were more likely to be yonger and male with lower initial FVC values then the completers. 
Allocation concealment $\mathrm{B}$ - Unclear

\begin{tabular}{|c|c|}
\hline Study & Knoell 1998 \\
\hline Methods & $\begin{array}{l}\text { DESIGN: Non-randomised Controlled Trial } \\
\text { MEANS OF ALLOCATION CONCEALMENT- Inadequate. Subjects alterantely assigned to a study } \\
\text { group. } \\
\text { OUTCOME ASSESSOR BLINDING- Yes } \\
\text { WITHDRAWAL/DROPOUTS - Not described }\end{array}$ \\
\hline Participants & $\begin{array}{l}\text { Eligible: } 188 \\
\text { Randomised: } 100 \text { (Intervention 45, Control 55) } \\
\text { Completed: } 100(45,55) \\
\text { Age: < } 25 \text { Int } 4 \text { Cont } 8,25 \text { to } 65 \text { Int } 37 \text {, Cont } 41,>65 \text { Int } 4 \text { Cont } 6 . \\
\text { Range: } \\
\text { Sex: Male/Female: Not stated } \\
\text { Asthma Diagnosis: Based on EPRII guidelines and symptoms. } \\
\text { Recruitment: Outpatients clinic } \\
\text { Diseases Included: All adults with asthma } \\
\text { Major Exclusions: COPD } \\
\text { Baseline: According to EPRII guidelines: Intermittent Int } 4.4 \% \text { Cont } 7.3 \% \text {, Mild persistent Int } 13.3 \% \text { Cont } \\
\text { 16.4\%, Moderate Int } 77.8 \% \text { Cont } 56.4 \% \text {, Severe Int } 4.4 \% \text { Cont } 20.0 \% \text {. } \\
\text { FEV1: } \\
\text { PEF: } \\
\text { Exacerbations: }\end{array}$ \\
\hline Interventions & $\begin{array}{l}\text { Setting: Outpatients Clinic } \\
\text { Type: Joint pharmacist and physician consultation covering general asthma concepts, triggers, medications } \\
\text { and written action plan. Provided with diary and instructed in use of peak flow monitoring. Assessed by } \\
\text { physician at the clinic. } \\
\text { Control group received routine outpatient care and were provided with a peakfow meter and diary. } \\
\text { Duration: } 1 \text { x 30-60minutes }\end{array}$ \\
\hline Outcomes & $\begin{array}{l}\text { Knowledge, hospitalisation, ER visits, Dr visits, Days off work, quality of life, compliance, quality of care, } \\
\text { drug costs, patient satisfaction }\end{array}$ \\
\hline Notes & Jadad Score $=2$ \\
\hline & $C-\ln a$ \\
\hline
\end{tabular}

\begin{tabular}{ll} 
Study & Kotses 1995 \\
\hline Methods & DESIGN: Randomised Controlled Trial \\
METHOD OF RANDOMISATION: the word “random" stated ; method not described. \\
METHOD OF ALLOCATION CONCEALMENT: not described. \\
OUTCOME ASSESSOR BLINDING: not stated. \\
WITHDRAWAL/DROPOUTS: all subjects accounted for. \\
\hline Pligible: 126 \\
Randomised: 85 \\
Completed: 76 (Intervention 36; Control 40) \\
Age: Overall mean: 49.8 yrs (sd 12.4) Range: 27 to 70 yrs \\
Sex: Male / Female 27/49 \\
Asthma Diagnosis: as per American Thoracic Society \\
Recruitment: participants whose asthma was generally under control \\
Diseases Included: not specified \\
Major exclusions: Fixed airways, concurrent uncontrolled medical conditions, occupational asthma, drug \\
abuse, obesity, low weight, cognitive or intellectual deficits. \\
\hline
\end{tabular}




\section{Characteristics of included studies (Continued)}

\begin{tabular}{|c|c|}
\hline & $\begin{array}{l}\text { Baseline: } \\
\text { FEV1: Patients described their asthma as moderate to severe. } \\
\text { PEF: am (intervention } 331+/-92 \text {; control } 333+/-123.7 \text { ) } \\
\text { Exacerbations: not stated }\end{array}$ \\
\hline Interventions & $\begin{array}{l}\text { Setting: not specified (? allergy clinic) } \\
\text { Type: Education and self monitoring of peak flow and symptoms } \\
\text { Control: No special education. Controls kept an asthma diary (symptoms and PEF) for } 6 \text { months on a daily } \\
\text { basis and again for } 2 \text { weeks prior to the } 12 \text { months follow-up. } \\
\text { Duration: } 7 \text { x } 90 \text { minute training sessions } 1 / \text { week over } 7 \text { weeks. }\end{array}$ \\
\hline Outcomes & $\begin{array}{l}\text { Knowledge, Hospitalisation, ER visits, doctor visits, PEF - evening daily average, quality of life (Beck De- } \\
\text { pression Inventory, Quality of Well-Being Scale), Wheeze, Exacerbations, Breathing difficulty, Coughing, } \\
\text { Chest tightness. }\end{array}$ \\
\hline \multicolumn{2}{|l|}{ Notes } \\
\hline Allocation concealment & B - Unclear \\
\hline Study & Kotses 1996 \\
\hline Methods & $\begin{array}{l}\text { DESIGN: } \\
\text { METHOD OF RANDOMISATION: Randomised - stated. Method not described. } \\
\text { MEANS OF ALLOCATION CONCEALMENT- not stated. } \\
\text { OUTCOME ASSESSOR BLINDING - not stated. } \\
\text { WITHDRAWAL/DROPOUTS - all subjects accounted for. }\end{array}$ \\
\hline Participants & $\begin{array}{l}\text { Eligible: not stated } \\
\text { Randomised: } 45 \\
\text { Completed: } 34 \\
\text { Age: Overall mean: } 42 \text { yrs Range: Not stated } \\
\text { Sex: Male/Female - } 7 / 27 \\
\text { Asthma Diagnosis: Self Reported moderate asthma for an average of } 16.5 \text { years. } \\
\text { Recruitment: community respondents to advertisements for research participants } \\
\text { Diseases Included: Not specified } \\
\text { Major exclusions: Not specified } \\
\text { Baseline: } \\
\text { FEV1: not specified. } \\
\text { PEF: Individual } 327+/-91.6 \text { group } 387+/-127.7 \text {, control } 310+/-105.2 . \\
\text { Exacerbations }\end{array}$ \\
\hline Interventions & $\begin{array}{l}\text { Setting: not stated } \\
\text { Type: Individual: daily self monitoring of PEFR, attacks \& contact with precipitants } \\
\text { Group: Group education and daily PF monitoring } \\
\text { Duration: Individual: } 60 \text { minute one to one session, Group: } 2 \times 2.5 \mathrm{hr} \text { education sessions }\end{array}$ \\
\hline Outcomes & $\begin{array}{l}\text { Outcomes measured after one month: ER visits, FEV1-(l/min evening), PEF(l/min evening), Activity Lim- } \\
\text { itation, Asthma Attacks. }\end{array}$ \\
\hline Notes & \\
\hline Allocation concealment & B - Unclear \\
\hline Study & Lahdensuo 1996 \\
\hline Methods & $\begin{array}{l}\text { DESIGN: Randomised Controlled Trial } \\
\text { METHOD OF RANDOMISATION: Randomised - blocks of variable sizes and stratified by centre } \\
\text { MEANS OF ALLOCATION CONCEALMENT- sealed number envelopes. } \\
\text { OUTCOME ASSESSOR BLINDING - single blind. } \\
\text { WITHDRAWAL/DROPOUTS - all subjects accounted for. }\end{array}$ \\
\hline
\end{tabular}




\section{Characteristics of included studies (Continued)}

\begin{tabular}{|c|c|}
\hline Participants & $\begin{array}{l}\text { Eligible: } 122 \\
\text { Randomised: } 122 \text { (Intervention 60, Control 62) } \\
\text { Completed: } 115 \text { (Intervention 56, Control 59) } \\
\text { Age: Overall mean: } 41.7 \text { yrs (sd 14.7) } \\
\text { Sex: Male/Female Intervention 43/59 } \\
\text { Asthma Diagnosis: Objective lung function } \\
\text { Recruitment: Out patient clinics in Finland - mild to moderately severe asthma. } \\
\text { Diseases Included: Smokers } \\
\text { Major exclusions: Not stated } \\
\text { Baseline: } \\
\text { FEV1: \% Predicted Intervention } 82.4 \text { (sd 15.8), Control } 81.7 \text { (16.6) } \\
\text { PEF: } \\
\text { Exacerbations: No oral corticosteroids in the last } 4 \text { weeks before entry. }\end{array}$ \\
\hline Interventions & $\begin{array}{l}\text { Setting: Outpatient clinics in Finland } \\
\text { Type: Optimal self management including a written action plan allowing self adjustment of anti-inflammatory } \\
\text { medications according to peak flow, self monitoring of peak flow, regular review within the program and } \\
\text { education. } \\
\text { Duration: At the first visit, one to one education was provided which took an extra } 1.5 \text { hrs longer then the } \\
\text { control visit. }\end{array}$ \\
\hline Outcomes & $\begin{array}{l}\text { Hosptialisations, Unscheduled doctor visits, FEV1, (\%predicted - pre bronchodilator), oral corticosteroids, } \\
\text { days off work or school, quality of life, courses of antibiotics, costs. }\end{array}$ \\
\hline Notes & Jadad Score $=3$ \\
\hline Allocation concealment & A - Adequate \\
\hline Study & Levy 2000 \\
\hline Methods & $\begin{array}{l}\text { DESIGN: Randomised Controlled Trial } \\
\text { METHOD OF RANDOMISATION: computer generated equal blocks of } 4 \\
\text { MEANS OF ALLOCATION CONCEALMENT- Random number list } \\
\text { OUTCOME ASSESSOR BLINDING - blinded } \\
\text { WITHDRAWAL/DROPOUTS- all participants accounted for. }\end{array}$ \\
\hline Participants & $\begin{array}{l}\text { Eligible: } \\
\text { Randomised: } 211 \text { (intervention 103, Control 108) } \\
\text { Completed: } 179 \text { (Intervention 83, Control 96). } \\
\text { Age: Mean(SE) Intervention 43(2), Control 40(2). } \\
\text { Range: not stated. } \\
\text { Sex: Male/Female: 80/131 } \\
\text { Asthma Diagnosis: not stated } \\
\text { Recruitment: prospective rolling recruitment over } 13 \text { months through hospital admissions and ER visits. } \\
\text { Diseases Included: } \\
\text { Major Exclusions: COPD } \\
\text { Baseline: severe } \\
\text { FEV1: } \\
\text { PEF: \% predicted before A\&E therapy: Int 49.1\%, Cont 44.8\%, after therapy Int62.8\% Cont } 59.5 \% \text {. } \\
\text { Exacerbations: }\end{array}$ \\
\hline Interventions & $\begin{array}{l}\text { Setting: Outpatients clinc } \\
\text { Type: Nurse advice and education of use of self-management plans, recognition and self treatment of un- } \\
\text { controlled asthma and when to seek medical help. Instructed when to step up medication if necessary using } \\
\text { PEF or symptoms. Use of "credit card" action plan. } \\
\text { Control group received usual care. } \\
\text { Both groups kept } 1 \text { week diary cards over } 3 \text { periods for data collection. }\end{array}$ \\
\hline
\end{tabular}




\section{Characteristics of included studies (Continued)}

Duration: $1 \mathrm{x} 1 \mathrm{hr}$ and $2 \mathrm{xhalf}$ hr sessions at 6 weekly intervals.

Outcomes $\quad$ ER visits, unscheduled \& scheduled Dr visits, PEF, rescue medication, inhaled corticosteroids, days off work, symptom score, quality of life.

\begin{tabular}{|c|c|}
\hline Notes & Jadad Score $=4$ \\
\hline Allocation concealment & A - Adequate \\
\hline Study & Mayo 1990 \\
\hline Methods & $\begin{array}{l}\text { DESIGN: Randomised controlled cross-over } \\
\text { METHOD OF RANDOMISATION: The word 'random' stated. Method of randomisation last digit on } \\
\text { hospital chart. } \\
\text { METHOD OF ALLOCATION CONCEALMENT: last digit on hospital chart. } \\
\text { OUTCOME ASSESSOR BLINDING: not stated. } \\
\text { WITHDRAWAL/DROPOUTS: all subjects accounted for. }\end{array}$ \\
\hline Participants & $\begin{array}{l}\text { Eligible: } 212 \\
\text { Randomised: } 104 \text { (Intervention 47, Control 57; } 19 \text { crossed to Intervention) } \\
\text { Completed: not stated } \\
\text { Age: Overall mean: } 44.3 \text { yrs Range: not stated } \\
\text { Sex: Male/Female - not stated } \\
\text { Asthma Diagnosis: American Thoriacic Society } \\
\text { Recruitment: Outpatients with prior hospitalisation for asthma } \\
\text { Diseases Included: Not stated } \\
\text { Major exclusions: Severe alcoholism, overt CNS or mental illness, deaf, mute. } \\
\text { Baseline: } \\
\text { FEV1: Not stated } \\
\text { PEF: Not stated } \\
\text { Exacerbations Not stated }\end{array}$ \\
\hline Interventions & $\begin{array}{l}\text { Setting: outpatient clinic } \\
\text { Type: Education, peak flow self monitoring and regular medical review. Patients were encouraged to initiate } \\
\text { self-treatmnt in the event of an exacerbation based on the physician's advice. } \\
\text { Duration: at least } 2 \text { hours one to one discussion with physician }\end{array}$ \\
\hline Outcomes & Skills, Hospitalisation, Mortality, Exacerbations, oral corticosteroids, inhaled corticosteroids. \\
\hline \multicolumn{2}{|l|}{ Notes } \\
\hline Allocation concealment & $\mathrm{C}$ - Inadequate \\
\hline
\end{tabular}

\begin{tabular}{ll} 
Study & Moudgil 2000 \\
\hline Methods & DESIGN: Randomised Controlled Trial \\
& METHOD OF RANDOMISATION: Computer randomisation \\
& MEANS OF ALLOCATION CONCEALMENT- Randomised prior to initial appointment \\
& OUTCOME ASSESSOR BLINDING- open \\
& WITHDRAWAL/DROPOUTS- all subjects accounted for \\
\hline Participants & Eligible: 1217 \\
& Randomised: 689 (Intervention 343, Control 346) \\
& Completed: 593 (Intervention 304, Control 289). \\
& Age: Overall Mean (sd) 34.5(15) Int 33.6(15.2), Cont 35.4(15.5) \\
& Range: eligible 11 to 59 \\
& Sex: Male/Female: 337/352 \\
& Asthma Diagnosis: Doctor diagnosis and objective lung function. \\
& Recruitment: 12 innercity General Practices \\
& Diseases Included: not stated \\
\hline
\end{tabular}




\section{Characteristics of included studies (Continued)}

\begin{tabular}{|c|c|}
\hline & $\begin{array}{l}\text { Major Exclusions: not stated } \\
\text { Baseline: } \\
\text { FEV1: Mean (sd) Int 2.4(0.89), Cont 2.42(0.88) } \\
\text { PEF: } \\
\text { Exacerbations: } n(\%) \text { past asthma admissions: Int } 115(33.5) \text {, Cont } 116(33.5)\end{array}$ \\
\hline Interventions & $\begin{array}{l}\text { Setting: ? at GP practices } \\
\text { Type: Emphasis on appropriate prescribing, optimising treatment, compliance, knowledge of disease severity. } \\
\text { Provision of peak flow meters and diaries for self monitoring throughout } 12 \text { months of study. Individual } \\
\text { written action plans. } \\
\text { Controls received usual care. } \\
\text { Duration: Individual } 40 \text { minute sessions reinforced at } 4 \text { and } 8 \text { months. }\end{array}$ \\
\hline Outcomes & $\begin{array}{l}\text { Hospitalisation, ER visits, scheduled \& unscheduled Dr visits, oral/inhaled corticosteroids, quality of life, } \\
\text { anitbiotic use. }\end{array}$ \\
\hline Notes & $\begin{array}{l}\text { Jadad Score }=4 \\
\text { White European and Indian subcontinent ethnic groups }\end{array}$ \\
\hline Allocation concealment & A-Adequate \\
\hline Study & Mulloy 1996 \\
\hline Methods & $\begin{array}{l}\text { DESIGN: } \\
\text { METHOD OF RANDOMISATION: Randomised - stated. Method not described. } \\
\text { MEANS OF ALLOCATION CONCEALMENT- not stated. } \\
\text { OUTCOME ASSESSOR BLINDING - not stated. } \\
\text { WITHDRAWAL/DROPOUTS - all participants accounted for. }\end{array}$ \\
\hline Participants & $\begin{array}{l}\text { Eligible: Not stated } \\
\text { Randomised: } 60 \text { (Intervention 30, Control 30) } \\
\text { Completed: } 46 \text { (after } 1 \text { month: Intervention 18, Control 28) (after } 12 \text { months: Intervention 12, Control 21) } \\
\text { Age: Overall mean: } 28.5 \text { years Range: not stated } \\
\text { Sex: Male/Female: Intervention } 47 \% / 53 \% \text { Control } 50 \% / 50 \% \\
\text { Asthma Diagnosis: Objective lung function } \\
\text { Recruitment: Hospital out patients } \\
\text { Diseases Included: not stated } \\
\text { Major exclusions: not stated } \\
\text { Baseline: } \\
\text { FEV1: Intervention mean } 2.98 \text { Control } 2.72 \\
\text { PEF: mean and standard error of the mean: Intervention } 394 \text { (32) Control } 361 \text { (22) } \\
\text { Exacerbations Not stated }\end{array}$ \\
\hline Interventions & $\begin{array}{l}\text { Setting: Outpatient clinic program run by an asthma nurse specialist } \\
\text { Type: Education via video and booklet, peak flow self monitoring and advised to seek regular review outside } \\
\text { the program. } \\
\text { Duration: one to one session of at least one hour. }\end{array}$ \\
\hline Outcomes & Knowledge, Inhaler technique, PEF, FEV1- baseline only, athma symptom severity \\
\hline \multicolumn{2}{|l|}{ Notes } \\
\hline Allocation concealment & B - Unclear \\
\hline Study & Neri 1996 \\
\hline Methods & $\begin{array}{l}\text { DESIGN: } \\
\text { METHOD OF RANDOMISATION: Randomised - stated. Method: alternation. } \\
\text { MEANS OF ALLOCATION CONCEALMENT- Not concealed, participants alternated. } \\
\text { OUTCOME ASSESSOR BLINDING - not blinded }\end{array}$ \\
\hline
\end{tabular}

Self-management education and regular practitioner review for adults with asthma (Review) 


\section{Characteristics of included studies (Continued)}

WITHDRAWAL/DROPOUTS - all participants accounted for.

\begin{tabular}{|c|c|}
\hline Participants & $\begin{array}{l}\text { Eligible: not stated } \\
\text { Randomised: } 80 \text { (Complete program 40, Reduced program 40) } \\
\text { Completed: } 65 \text { (Complete 33, Reduced 32) } \\
\text { Age: Overall mean: } 45.5 \text { years Range: not stated } \\
\text { Sex: Male/Female: } 25 / 40 \\
\text { Asthma Diagnosis: according to international guidelines - Dr diagnosis implied. } \\
\text { Recruitment: Outpatients department. } \\
\text { Diseases Included: Smokers } \\
\text { Major exclusions: not stated } \\
\text { Baseline: } \\
\text { FEV1: Complete } 78.3 \text { (sd } 15.3 \text { ), Reduced } 73.4 \text { (sd 16.9) } \\
\text { PEF: not stated } \\
\text { Exacerbations: not stated }\end{array}$ \\
\hline Interventions & $\begin{array}{l}\text { Setting: Asthma School } \\
\text { Type: Intervention: Group asthma education in an asthma school including a booklet and video. Content } \\
\text { included self monitoring of peak flow, interpretation and use of drugs, mechanisms and triggers. } \\
\text { Control: reduced education program involving self reading of a booklet and peak-flow monitoring and } \\
\text { recording. } \\
\text { Duration: } 6 \text { x } 1 \text { hr lessons in groups of } 10 \text {. ( } 2 \text { per week for } 5 \text { lessons and the last lesson after } 3 \text { months as a } \\
\text { reinforcer. }\end{array}$ \\
\hline Outcomes & $\begin{array}{l}\text { FEV1 (\% predicted), admission days, urgent doctor visits, rescue medication, morbidity savings, days of } \\
\text { work or school. }\end{array}$ \\
\hline \multicolumn{2}{|l|}{ Notes } \\
\hline Allocation concealment & $\mathrm{C}$ - Inadequate \\
\hline
\end{tabular}

\section{Study}

Methods

\section{Schott-Baer 1999}

DESIGN: Randomised Controlled Trial

METHOD OF RANDOMISATION: Random stated but assigned to groups according to the last digit of their hospital record number -even to intervention, odd to control group.

MEANS OF ALLOCATION CONCEALMENT- not concealed

OUTCOME ASSESSOR BLINDING- not stated WITHDRAWAL/DROPOUTS-

\begin{tabular}{ll}
\hline Participants & Eligible: not stated \\
& Randomised: 36 (Intervention 17, Control 19) \\
& Completed: 22 (Intervention 15, Control 7) \\
& Age: Mean Int 44yrs, Cont 52 yrs \\
& Range: 24-74 yrs \\
& Sex: Male / Female: $4 / 32$ \\
& Asthma Diagnosis: Doctor diagnosis. Recently diagnosed asthma. \\
& Recruitment: Outpatient clincs \\
& Diseases Included: \\
& Major Exclusions: COPD, chronic bronchitis. \\
& Baseline: \\
& FEV1: \\
& PEF: \\
& Exacerbations: \\
\hline Setting: Outpatients Clinic \\
Type: Education on disease process, daily self monitoring, self- management techniques, and daily log \\
completion including peak flow, triggers, and ratings of benefits. \\
\hline Interventions
\end{tabular}




\section{Characteristics of included studies (Continued)}

Controls received standard care and some information on medications and insrtuction on daily recording of peak flow-not self monitoring diary.

Duration: 1 x 3 hr session -? individual or group. 3 reinforcement phonecalls

\begin{tabular}{ll}
\hline Outcomes & Knowledge, ER visits, Peak flow, clinic visits \\
\hline Notes & Jadad Score $=4$ \\
\hline Allocation concealment & C - Inadequate \\
\hline
\end{tabular}

\section{Study}

Methods

\section{Shields 1986}

DESIGN: Block randomised according to the number of ER visits or hospitalisations

METHOD OF RANDOMISATION: Randomised - stated. Method: not described.

MEANS OF ALLOCATION CONCEALMENT- not described.

OUTCOME ASSESSOR BLINDING -not described.

WITHDRAWAL/DROPOUTS - not described.

\begin{tabular}{ll}
\hline Participants & Eligibility Criteria: > 18 years, at least 1 ER visits or hospitalisation for asthma in prior 4 years. \\
& Eligible: 103 \\
& Randomised: 103 \\
& Completed: 87 \\
& Age: mean: Not specified; Range Not specified. \\
& Sex: Male/Female - not specified. \\
& Asthma Diagnosis: Dr diagnosis implied as previously hospitalised or visited ER for asthma \\
& Recruitment: from prior ER visit or Hospitalisation \\
& Major exclusions: not specified \\
& Baseline \\
& FEV1 not stated; \\
& PEF not stated, \\
& Exacerbations: ER visit or hospitalisation in previous 4 years. \\
\hline Interventions & Setting: HMO classes \\
& Type: Group education in $4 \mathrm{x} 1.5$ hour classes OR telephone counselling. Classes or counselling were followed \\
& by telephone follow-up according to individual patients' needs. \\
& Content: physiology of asthma, medications, respiratory infections, inflammation, use of HMO resources. \\
& Duration: Classes $4 \mathrm{x} 1.5$ hours. \\
\hline Outcomes & ER visits, cost. \\
\hline Notes & B - Unclear \\
\hline Allocation concealment & \\
\hline
\end{tabular}

\begin{tabular}{ll} 
Study & Snyder $\mathbf{1 9 8 7}$ \\
\hline Methods & DESIGN: Randomised Controlled Trial \\
& METHOD OF RANDOMISATION: Random stated. Method not described. \\
& METHOD OF ALLOCATION CONCEALMENT: not described. \\
& OUTCOME ASSESSOR BLINDING: unclear \\
& WITHDRAWAL/DROPOUTS: all subjects accounted for. \\
\hline Participants & Eligible: ? \\
& Randomised: 79 \\
& Completed: 75 \\
& Age: Overall mean: 27.6 Range: not stated \\
& Sex: Male/Female: $34 / 41$ \\
& Asthma Diagnosis: Doctor Diagnosis / Objective Lung Function \\
& Recruitment: Community volunteers \\
& Diseases Included: not stated \\
\hline
\end{tabular}




\section{Characteristics of included studies (Continued)}

\begin{tabular}{ll} 
Major exclusions: smoking, fixed airway disease, other uncontrolled diseases, substance abuse, potential \\
complicating physical disorders / obesity / little obstruction. \\
Baseline: \\
FEV1: \\
PEF: \\
Exacerbations \\
\hline Setting: not stated. \\
Type: education and probably peak flow self-monitoring \\
Duration: 2 x 2.5 hrs group education sessions \\
\hline Outcomes & Knowledge, hospital visits, ER visits, Doctor visits, quality of life (asthma attitude survey for adults), days of \\
& work, amounts and type of medications for asthma, exacerbations. \\
\hline
\end{tabular}

Notes

Outcomes data are not provided in a form appropriate for meta-analysis. Several attempts have been made to contact the authors.

Allocation concealment $\mathrm{B}-$ Unclear

\begin{tabular}{|c|c|}
\hline Study & Sommaruga 1995 \\
\hline Methods & $\begin{array}{l}\text { DESIGN: } \\
\text { METHOD OF RANDOMISATION: Randomised - stated. Method not described. } \\
\text { MEANS OF ALLOCATION CONCEALMENT- not stated. } \\
\text { OUTCOME ASSESSOR BLINDING - not stated. } \\
\text { WITHDRAWAL/DROPOUTS - all participants accounted for. }\end{array}$ \\
\hline Participants & $\begin{array}{l}\text { Eligible: not stated } \\
\text { Randomised: } 40 \text { (Intervention 20, Control 20) } \\
\text { Completed: } 36 \text { (Intervention 20, Control 16) } \\
\text { Age: Overall mean: } 48 \text { Range: +/-16 yrs } \\
\text { Sex: Male/Female : 21/19 } \\
\text { Asthma Diagnosis: Dr diagnosis implied: International Guidelines } \\
\text { Recruitment: Hospital inpatients at a Respiratory Medical Centre } \\
\text { Diseases Included: Not stated } \\
\text { Major exclusions: Not stated } \\
\text { Baseline: } \\
\text { FEV1: } 76+/-18 \% \text { predicted before and } 94+/-5 \% \text { predicted after salbutamol. } \\
\text { PEF: not stated } \\
\text { Exacerbations: not stated. }\end{array}$ \\
\hline Interventions & $\begin{array}{l}\text { Setting: Inpatient education programme } \\
\text { Type: Education, peak flow medications and symptoms self monitoring, medical review every } 2 \text { months with } \\
\text { the same physician, written action plan allowing the patient to alter medications in response to worsening } \\
\text { asthma. (plus a psychological intervention). } \\
\text { Duration: } 2 \text { lessons during admissions of unknown duration and quarterly lessons during the ensuring year. }\end{array}$ \\
\hline Outcomes & $\begin{array}{l}\text { Hospitalisation, ER visits, Days off work, Asthma Attacks, Resp. Illness Opinion Survey, Health Locus } \\
\text { of Control, STA1 x } 2 \text { (anxiety, AD (Depression) APF (psychophysiological disorders), Asthma Symptom } \\
\text { Checklist. - Only reported the psychological outcomes. }\end{array}$ \\
\hline Notes & Jadad Score $=3$ \\
\hline llocation concealment & B - Unclear \\
\hline
\end{tabular}

\begin{tabular}{ll} 
Study & Wilson 1993 \\
\hline Methods & DESIGN: Randomised controlled trial. \\
& METHOD OF RANDOMISATION: Random stated. Blocked according to severity. Method not described.
\end{tabular}




\section{Characteristics of included studies (Continued)}

METHOD OF ALLOCATION CONCEALMENT: not described.

OUTCOME ASSESSOR BLINDING: physicians who assessed asthma status were blinded as to group assignment of patients. Unclear whether the nurse who administered quesionnnaires and assessed MDI technique was blinded.

WITHDRAWAL/DROPOUTS: participants not accounted for.

\begin{tabular}{|c|c|}
\hline Participants & $\begin{array}{l}\text { Eligible: } 579 \\
\text { Randomised: } 323 \text { (at } 5 \text { months = 271) (at } 12 \text { months = 277) } \\
\text { Completed: not described } \\
\text { Age: (eligibility was } 18 \text { to } 50 \text { years) Overall mean: ? Group mean ? Individual mean ?; Information Only } \\
\text { mean ? Range: ? (p566 "no significant difference with respect to gender, age, level of education, asthma } \\
\text { severity. } \\
\text { Sex: Male/Female - not stated - see above } \\
\text { Asthma Diagnosis: Dr diagnosis and objective lung function } \\
\text { Recruitment: Community: patients of the Kaiser Medical Centers in California. } \\
\text { Included: Moderate - severe asthma, Dr's diagnosis. } \\
\text { Major exclusions: Irreversible respiratory disease, emphysema, COPD. } \\
\text { Baseline: recurrent wheeziness } \\
\text { FEV1: > } 15 \% \text { change } \\
\text { PEF: } 20 \% \text { variability } \\
\text { Exacerbations: History of recurrent episodes of wheezing and/or objective evidence of airflow obstruction } \\
\text { during episodes and improved airflow when treated with a bronchodilator. }\end{array}$ \\
\hline Interventions & $\begin{array}{l}\text { Setting: Kaiser Permanente Patients } \\
\text { Type: } 3 \text { Types of intervention as follows: } \\
\text { (1) Group education, symptoms and peak flow monitoring, reviewed at } 5 \text { and } 12 \text { months. } \\
\text { (2) Individual education, (as per intervention } 1 \text { except individual education). } \\
\text { (3) Information Only control: patients were given a workbook to read and reviewed at } 5 \text { and } 12 \text { months. } \\
\text { Controls were given no special education but were reviewed at } 5 \text { and } 12 \text { months. } \\
\text { Duration: Individual - } 180 \text { minutes per patient, Group } 45 \text { to } 60 \text { minutes per patient. }\end{array}$ \\
\hline Outcomes & $\begin{array}{l}\text { Knowledge, hospitalisation, ER Visits, PEF ( } 1 / \mathrm{min}) \text {, FEV1(\% predicted), rescue medication, oral corticos- } \\
\text { teroids, inhaled corticosteroids, symptomatic days, physician evaluation of asthma status, relative bother, } \\
\text { change in physical activity, improvement in bedroom environment, inhaler technique. }\end{array}$ \\
\hline Notes & \\
\hline Allocation concealment & B - Unclear \\
\hline Study & Yoon 1993 \\
\hline Methods & $\begin{array}{l}\text { DESIGN: Randomised Controlled Trial } \\
\text { METHOD OF RANDOMISATION: Random stated. Method not described. } \\
\text { METHOD OF ALLOCATION CONCEALMENT: not described. } \\
\text { OUTCOME ASSESSOR BLINDING: not stated. } \\
\text { WITHDRAWAL/DROPOUTS: all participants accounted for. }\end{array}$ \\
\hline Participants & $\begin{array}{l}\text { Eligible: not stated } \\
\text { Randomised: } 76 \text { (Intervention 37, Control 39) } \\
\text { Completed: } 56 \text { after } 10 \text { months } \\
\text { Age: Overall mean: } 32 \text { yrs Range: } 16 \text { to } 65 \text { years } \\
\text { Sex: Male/Female: not stated } \\
\text { Asthma Diagnosis: Objective Lung Function } \\
\text { Recruitment: hosptial admission for asthma } \\
\text { Diseases Included: not stated } \\
\text { Major exclusions: irreversible airway obstruction, significant concurrent diseases. } \\
\text { Baseline: } \\
\text { FEV1: reversibility of at least } 15 \% \text { predicted. }\end{array}$ \\
\hline
\end{tabular}




\section{Characteristics of included studies (Continued)}

\begin{tabular}{|c|c|}
\hline & $\begin{array}{l}\text { PEF: not stated } \\
\text { Exacerbations: not stated. }\end{array}$ \\
\hline Interventions & $\begin{array}{l}\text { Setting: Asthma education centre connected with a tertiary teaching hospital } \\
\text { Type: Optimal self management including education, peak flow self monitoring, regular review and a written } \\
\text { action plan enabling self adjustment of medications based on peak flow for worsening asthma. } \\
\text { Duration: } 3 \text { hours total }\end{array}$ \\
\hline Outcomes & $\begin{array}{l}\text { Knowledge, Hospitalisation, ER visits, Lung function ( } 1 / \mathrm{min}) \text {, Inhaled corticosteroids, quality of life (psy- } \\
\text { chosocial disturbance du to asthma) days off work, wheeze (frequency and severity). }\end{array}$ \\
\hline \multicolumn{2}{|l|}{ Notes } \\
\hline Allocation concealment & B - Unclear \\
\hline Study & Zeiger 1991 \\
\hline Methods & $\begin{array}{l}\text { DESIGN: Controlled Clinical Trial } \\
\text { METHOD OF RANDOMISATION: Not randomised } \\
\text { MEANS OF ALLOCATION CONCEALMENT- alternation / day of their ER vist, not concealed. } \\
\text { OUTCOME ASSESSOR BLINDING - “evaluated blindly" - p1160. } \\
\text { WITHDRAWAL/DROPOUTS - all subjects accounted for. }\end{array}$ \\
\hline Participants & $\begin{array}{l}\text { Eligible: not stated } \\
\text { Randomised: } 309 \text { (Intervention 149, Control 160) } \\
\text { Completed: } 249 \text { (Intervention 110, Control 139) } \\
\text { Age: Overall mean: } 24.4 \text { sd: } 14.5 \\
\text { Sex: Male/Female: } 42.6 \% / 57.4 \% \\
\text { Asthma Diagnosis: as per American Thoracic Society } \\
\text { Recruitment: Emergency Room } \\
\text { Diseases Included: smokers } \\
\text { Major exclusions: previous allergy or pulmonary care. COPD } \\
\text { Baseline: } \\
\text { FEV1: not stated } \\
\text { PEF: \% pred. on admission: mean (sd) Intervention } 46.7 \text { (19.9), Control } 52 \text { (24.9) } \\
\text { Exacerbations acute wheezing or dyspnea at the time of the index visit. }\end{array}$ \\
\hline Interventions & $\begin{array}{l}\text { Setting: Allergy Clinic - HMO } \\
\text { Type: Expedited allegy assessment and education; peak flow self monitoring, regular review and written } \\
\text { action plan enabling self adjustment of medications in response to worsening asthma } \\
\text { Duration: one to one sessions of unknown number and duration. }\end{array}$ \\
\hline Outcomes & Hospitalisation, ER Visits, Inhaled Corticosteroids, Nocturnal Asthma, Perception of Asthma. \\
\hline Notes & \\
\hline & Possible contamination: 21 control subjects referred to an allergist \\
\hline Allocation concealment & $\mathrm{C}$ - Inadequate \\
\hline Study & de Oliveira 1999 \\
\hline Methods & $\begin{array}{l}\text { DESIGN:Randomised Controlled Trial } \\
\text { METHOD OF RANDOMISATION: Randomised - stated. Method not described } \\
\text { MEANS OF ALLOCATION CONCEALMENT- closed envelope technique } \\
\text { OUTCOME ASSESSOR BLINDING- Not stated } \\
\text { WITHDRAWAL/DROPOUTS- }\end{array}$ \\
\hline Participants & $\begin{array}{l}\text { Eligible: } 80 \\
\text { Randomised: } 53(26 / 27) \\
\text { Completed: } 42(22 / 20) \\
\text { Age: Mean overall } 39.6 \text { yrs. intervention } 41 \text { (sd15), Control } 38(\operatorname{sd} 17)\end{array}$ \\
\hline
\end{tabular}




\begin{tabular}{l} 
Range: not stated \\
Sex: Male / Female: $5 / 37$ \\
Asthma Diagnosis: history airflow obstruction and ICRDMA criteria \\
Recruitment: Outpatient clinic database \\
Diseases Included: not stated \\
Major Exclusions: not stated \\
Baseline: \\
FEV1: percent predicted: Intervention 70\%(sd22), Control 80\% (sd19) \\
PEF: \\
Exacerbations: \\
Setting: Outpatients clinic \\
Type: concepts of asthma, asthma management, triggers, preventive measures. Video with introduction \\
to treatment plan and inhaler technique. Symptom self monitoring. Medcially assessed at baseline and \\
completion. Treament adjusted according to ICRDMA recommendations. \\
Controls received routine schedule of asthma clinic. Medically assessed at baseline and completion \\
Duration: Monthly visits for 6 months ? length of time but including $1 \mathrm{x}$ individual session and $2 \mathrm{x} 1 \mathrm{hr}$ \\
group sessions at 3 and 4 months . \\
\hline Knowledge, skills, hospitalisations, ER visits, PEF, rescue medications, oral \& inhaled corticosteroids, symp- \\
tom frequency and quality of life. \\
\hline Jadad Score = 4 \\
\hline Outcomes
\end{tabular}

\section{Characteristics of excluded studies}

\begin{tabular}{|c|c|}
\hline \multirow[b]{2}{*}{ Abdulwadud 1997} & Reason for exclusion \\
\hline & Baseline data only \\
\hline Adams 2001 & Comparison of two educational interventions \\
\hline Aiolfi 1995 & Information only education \\
\hline Amirav 1995 & Not patient education \\
\hline Ayres 1996 & Comparison of two educational interventions \\
\hline Baldwin 1997 & Comparison of two educational interventions \\
\hline Bolton 1991 & Information only education \\
\hline Boulet 1995 & Methodological problems \\
\hline Charlton 1990 & Comparison of two educational interventions \\
\hline Cote 2001 & Comparison of two educational interventions \\
\hline Cox 1993 & Not an education intervention \\
\hline Erickson 1998 & Sample size too small, not an RCT \\
\hline Gergen 1995 & Non-RCT \\
\hline Graft 1991 & Non-RCT \\
\hline Grainger-Rousseau & Not randomised. Children included. Mean age unknown \\
\hline Grampian 1994b & Not education intervention \\
\hline Hausen 1999 & Non-RCT \\
\hline Heringa 1987 & Inappropriate outcomes \\
\hline Hindi-Alexander 1987 & non-RCT \\
\hline Hoskins 1996 & Methodological problems \\
\hline
\end{tabular}




\section{Characteristics of excluded studies (Continued)}

Huss 1992

Information only education

Jackevicius $1999 \quad$ Inhaler technique

Janson-Bjerklie 1988 Not an education intervention

Jenkinson $1988 \quad$ Information only education

Jones $1987 \quad$ Outcomes not appropriate

Kauppinen $1998 \quad$ Comparison of two educational interventions

Kelso $1995 \quad$ Non-RCT

Klein $2001 \quad$ Comparison of two educational interventions

LeBaron $1985 \quad$ Not an education intervention

Legorreta $2000 \quad$ Not an RCT

Lirsac $1991 \quad$ Not a education intervention

Lopez-Vina $2000 \quad$ Comparison of two educational interventions

Maes $1988 \quad$ Not an education intervention

Maiman $1979 \quad$ Information only education

Moldofsky $1979 \quad$ Information only education

Muhlhauser $1991 \quad$ Non-RCT

Osman $1994 \quad$ Information only education

Perdomo-Ponce 1996 Not an RCT. Focus on allergic diseases and therapeutic compliance

Petro $1995 \quad$ Not predominantly asthma

Premaratne $1999 \quad$ Nurse education

Ringsberg $1990 \quad$ Information only education

Rydman $1999 \quad$ Inhaler technique

Sondergaard $1992 \quad$ Information only education

Thapar $1994 \quad$ Information only education

Tougaard $1992 \quad$ Not predominantly asthma

Turner $1998 \quad$ Comparison of two educational interventions

Verver $1996 \quad$ Inhaler technique only

White $1989 \quad$ Not patient education

\section{Characteristics of ongoing studies}

\begin{tabular}{ll} 
Study & Ford $\mathbf{1 9 9 6}$ \\
\hline Trial name or title & An empowerment-cnetered, church-based asthma education program for African American adults \\
\hline Participants & African-American adults with asthma \\
\hline Interventions & General physiology of asthma, , identification of stressors, problem solving, medications, PEF monitoring \\
\hline Outcomes & knowledge, ED visits, PEFV and inhaler technique, quality of life, perceived illness \\
\hline Starting date & 1996 \\
\hline Contact information & \\
\hline Notes & Ploska $\mathbf{1 9 9 9}$ \\
\hline Study & An education based hospital nursing programme in the treatment of asthma \\
\hline Trial name or title & \\
\hline $\begin{array}{l}\text { Self-management education and regular practitioner review for adults with asthma (Review) } \\
\text { Copyright } \odot \mathbf{2 0 0 8} \text { The Cochrane Collaboration. Published by John Wiley \& Sons, Ltd }\end{array}$
\end{tabular}




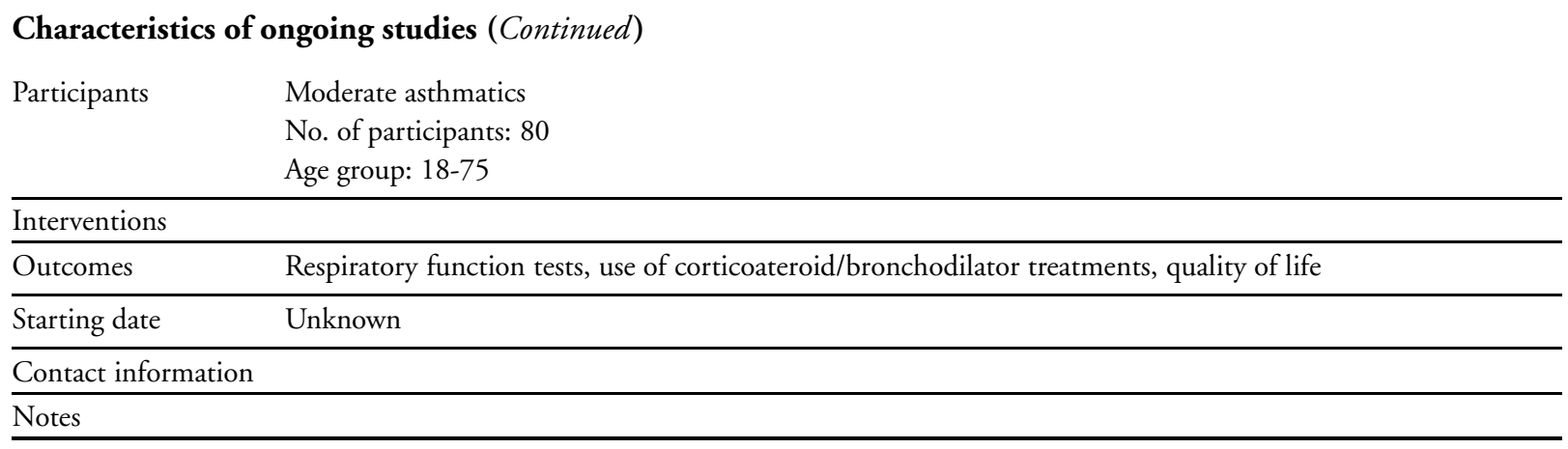

\section{A N A L Y S E S}

\section{Comparison 01. Self Management versus Usual Care}

\begin{tabular}{|c|c|c|c|c|}
\hline Outcome title & $\begin{array}{l}\text { No. of } \\
\text { studies }\end{array}$ & $\begin{array}{c}\text { No. of } \\
\text { participants }\end{array}$ & Statistical method & Effect size \\
\hline $\begin{array}{l}01 \text { Hospitalisations (\% subjects } \\
\text { hospitalised) }\end{array}$ & 12 & 2418 & Relative Risk (Fixed) 95\% CI & $0.64[0.50,0.82]$ \\
\hline 02 Hospitalisations (mean) & 5 & 744 & Standardised Mean Difference (Fixed) 95\% CI & $-0.01[-0.17,0.15]$ \\
\hline 03 ER Visits (\% subjects) & 13 & 2902 & Relative Risk (Fixed) 95\% CI & $0.82[0.73,0.94]$ \\
\hline 04 ER Visits (Mean) & 8 & 731 & Standardised Mean Difference (Fixed) 95\% CI & $-0.36[-0.50,-0.21]$ \\
\hline 05 Unscheduled Dr Visits (mean) & 7 & 1042 & Standardised Mean Difference (Fixed) 95\% CI & $-0.07[-0.19,0.06]$ \\
\hline $\begin{array}{l}06 \text { Unscheduled Dr Visits (\% } \\
\text { subjects) }\end{array}$ & 7 & 1556 & Relative Risk (Fixed) 95\% CI & $0.68[0.56,0.81]$ \\
\hline 07 Days off work (\% subjects) & 7 & 732 & Relative Risk (Fixed) 95\% CI & $0.79[0.67,0.93]$ \\
\hline 08 Days off work (mean) & 13 & 1728 & Standardised Mean Difference (Fixed) 95\% CI & $-0.18[-0.28,-0.09]$ \\
\hline 09 Nocturnal Asthma (\% subjects) & 5 & 1136 & Relative Risk (Fixed) 95\% CI & $0.67[0.56,0.79]$ \\
\hline 10 FEV1 (mean) & 7 & 1072 & Standardised Mean Difference (Fixed) 95\% CI & $0.10[-0.02,0.22]$ \\
\hline 11 Peak Expiratory Flow (mean) & 10 & 1346 & Standardised Mean Difference (Fixed) 95\% CI & $0.18[0.07,0.29]$ \\
\hline $\begin{array}{l}12 \text { Hospitalisations (mean total } \\
\text { days) }\end{array}$ & & & Weighted Mean Difference (Fixed) 95\% CI & Subtotals only \\
\hline $\begin{array}{l}13 \text { Rescue Medication Use (\% } \\
\text { subjects) }\end{array}$ & 2 & 233 & Relative Risk (Fixed) 95\% CI & $1.01[0.95,1.07]$ \\
\hline $\begin{array}{l}14 \text { Quality of Life Total Score } \\
\text { (mean) }\end{array}$ & 6 & 515 & Standardised Mean Difference (Fixed) 95\% CI & $0.29[0.11,0.47]$ \\
\hline 15 Quality of Life Impact (mean) & 2 & 268 & Standardised Mean Difference (Fixed) 95\% CI & $0.23[-0.02,0.47]$ \\
\hline 16 Quality of Life Activity (mean) & 3 & 281 & Standardised Mean Difference (Fixed) 95\% CI & $0.16[-0.07,0.40]$ \\
\hline $\begin{array}{l}17 \text { Quality of Life Symptoms } \\
\text { (mean) }\end{array}$ & 3 & 281 & Standardised Mean Difference (Fixed) 95\% CI & $-0.09[-0.33,0.14]$ \\
\hline 18 Total Direct Costs (mean) & 2 & 185 & Standardised Mean Difference (Fixed) 95\% CI & $0.39[0.10,0.68]$ \\
\hline 19 Total Indirect Costs (mean) & 2 & 185 & Standardised Mean Difference (Fixed) $95 \%$ CI & $-0.40[-0.69,-0.11]$ \\
\hline 20 Total Costs (mean) & 2 & 185 & Standardised Mean Difference (Fixed) 95\% CI & $-0.26[-0.55,0.03]$ \\
\hline
\end{tabular}

\section{INDEX TERMS}

\section{Medical Subject Headings (MeSH)}

Adolescent; Asthma [rehabilitation; * therapy]; Emergencies; Hospitalization; * Outcome Assessment (Health Care); ${ }^{*}$ Patient Education as Topic; Randomized Controlled Trials as Topic; *Self Care

\section{MeSH check words}

Adult; Humans

Self-management education and regular practitioner review for adults with asthma (Review)

Copyright () 2008 The Cochrane Collaboration. Published by John Wiley \& Sons, Ltd 


\section{COVER SHEET}

Title

Authors

Contribution of author(s)

Issue protocol first published

Review first published

Date of most recent amendment

Date of most recent

SUBSTANTIVE amendment

What's New

\section{Date new studies sought but none found}

Date new studies found but not yet included/excluded Date new studies found and
included/excluded

Date authors' conclusions section amended

Contact address
Self-management education and regular practitioner review for adults with asthma

Gibson PG, Powell H, Coughlan J, Wilson AJ, Abramson M, Haywood P, Bauman A, Hensley MJ, Walters EH

Gibson PG - insitigator of the review and conceptual direction - inclusion/exclusion, quality assessment, data extraction, analysis and interpretation, writing and editing.

Powell $\mathrm{H}$ - responsible for review update, inclusion/exclusion, quality assessment, data extraction, analysis, interpretation and writing.

Coughlan JL - inclusion/exclusion, quality assessment, data extraction, analysis, interpretation and writing.

Wilson A - inclusion/exclusion, quality assessment, data extraction and writing.

Hensley MJ - text of review and intelectual direction and input.

Bauman A - input of some guiding concepts particularly in regards to educational principles. Abramson MJ - inclusion/exclusion, review of text and concepts.

Walters EH - academic input.

1998/1

1999/1

18 August 2004

12 March 2002

This review is an update of the existing "Self-management education and regular practitioner review for adults with asthma". Thirty six trials comparing asthma self-management education with a usual care control group have been included. Thirteen new trials have been added with this update. We have removed three trials from the original review that did not have a control group and compared two options for self-management education. These have been included in a third review "Options for self-management education for adults with asthma”. Two new outcomes, quality of life and costs, have also been evaluated. The conclusions of the review are unchanged.

Information not supplied by author

Information not supplied by author

12 March 2002

12 March 2002

Dr Peter Gibson

Department of Respiratory and Sleep Medicine

John Hunter Hospital

Locked Bag 1

Hunter Mail Centre

NSW

2310

AUSTRALIA

E-mail: mdpgg@mail.newcastle.edu.au

Tel: +61 249855766 
Fax: +61249855850

DOI

Cochrane Library number

Editorial group

Editorial group code
10.1002/14651858.CD001117

CD001117

Cochrane Airways Group

HM-AIRWAYS

GRAPHS AND OTHER TABLES

Analysis 01.0I. Comparison 0I Self Management versus Usual Care, Outcome 0 I Hospitalisations (\% subjects hospitalised)

\begin{tabular}{|c|c|c|c|c|c|}
\hline \multicolumn{6}{|c|}{ Comparison: 0 I Self Management versus Usual Care } \\
\hline & & & & & \\
\hline \multirow[t]{2}{*}{ Study } & Self Management & Usual Care & Relative Risk (Fixed) & Weight & Relative Risk (Fixed) \\
\hline & $\mathrm{n} / \mathrm{N}$ & $\mathrm{n} / \mathrm{N}$ & $95 \% \mathrm{Cl}$ & (\%) & $95 \% \mathrm{Cl}$ \\
\hline \multicolumn{6}{|l|}{ OI Optimal Self Management } \\
\hline Cote 1997 & $2 / 50$ & $2 / 54$ & & 1.4 & $1.08[0.16,7.38]$ \\
\hline Cowie 1997 & $2 / 46$ & $6 / 48$ & \begin{tabular}{l|l}
$\cdot$ \\
\end{tabular} & 4.3 & $0.35[0.07,1.64]$ \\
\hline Ghosh 1998 & $38 / 140$ & $50 / 136$ & - & 37.4 & $0.74[0.52,1.05]$ \\
\hline Heard 1999 & $2 / 97$ & $5 / 94$ & & 3.7 & $0.39[0.08,1.95]$ \\
\hline Ignacio-Garcia 1995 & 0/35 & $5 / 35$ & 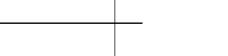 & 4.1 & $0.09[0.01,1.58]$ \\
\hline Lahdensuo 1996 & $2 / 56$ & $3 / 59$ & & 2.2 & $0.70[0.12,4.05]$ \\
\hline Moudgil 2000 & $10 / 304$ & $18 / 289$ & 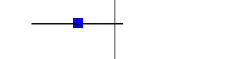 & 13.6 & $0.53[0.25,1.12]$ \\
\hline Yoon 1993 & 1/28 & $7 / 28$ & & 5.2 & $0.14[0.02,1.09]$ \\
\hline Zeiger 1991 & $2 / 149$ & $5 / 160$ & & 3.6 & $0.43[0.08,2.18]$ \\
\hline Subtotal (95\% CI) & 905 & 903 & 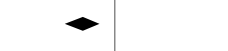 & 75.4 & $0.58[0.43,0.77]$ \\
\hline \multicolumn{6}{|c|}{ Total events: 59 (Self Management), I0I (Usual Care) } \\
\hline \multicolumn{6}{|c|}{ Test for heterogeneity chi-square $=6.63 \mathrm{df}=8 \mathrm{p}=0.58 \mathrm{I}^{2}=0.0 \%$} \\
\hline \multicolumn{6}{|c|}{ Test for overall effect $z=3.75 \quad p=0.0002$} \\
\hline \multicolumn{6}{|c|}{02 Self Monitoring and Regular Review } \\
\hline Garret 1994 & $20 / 251$ & $25 / 249$ & $\longrightarrow$ & 18.5 & $0.79[0.45,1.39]$ \\
\hline Subtotal $(95 \% \mathrm{CI})$ & 251 & 249 & & 18.5 & $0.79[0.45,1.39]$ \\
\hline \multicolumn{6}{|c|}{ Total events: 20 (Self Management), 25 (Usual Care) } \\
\hline \multicolumn{6}{|c|}{ Test for heterogeneity: not applicable } \\
\hline Test for overall effect $z=0.81$ & $=0.4$ & & & & \\
\hline 03 Self Monitoring Only & & & & & \\
\hline
\end{tabular}




\begin{tabular}{|c|c|c|c|c|c|}
\hline Study & $\begin{array}{c}\text { Self Management } \\
n / N\end{array}$ & $\begin{array}{c}\text { Usual Care } \\
n / N\end{array}$ & $\begin{array}{c}\text { Relative Risk (Fixed) } \\
95 \% \mathrm{Cl}\end{array}$ & $\begin{array}{c}\text { Weight } \\
(\%)\end{array}$ & $\begin{array}{c}\text { Relative Risk (Fixed) } \\
\qquad 95 \% \mathrm{Cl}\end{array}$ \\
\hline Brewin 1995 & $4 / 12$ & $10 / 33$ & & 3.9 & $1.10[0.42,2.85]$ \\
\hline Neri 1996 & $2 / 32$ & $3 / 33$ & & 2.2 & $0.69[0.12,3.85]$ \\
\hline Subtotal $(95 \% \mathrm{CI})$ & 44 & 66 & - & 6.1 & $0.95[0.41,2.21]$ \\
\hline \multicolumn{6}{|c|}{ Total events: 6 (Self Management), I3 (Usual Care) } \\
\hline \multicolumn{6}{|c|}{ Test for heterogeneity chi-square $=0.23 \mathrm{df}=|\mathrm{p}=0.64|^{2}=0.0 \%$} \\
\hline \multicolumn{6}{|c|}{ Test for overall effect $z=0.11 \quad p=0.9$} \\
\hline Total $(95 \% \mathrm{CI})$ & 1200 & 1218 & $\hookrightarrow$ & 100.0 & $0.64[0.50,0.82]$ \\
\hline \multicolumn{6}{|c|}{ Total events: 85 (Self Management), 139 (Usual Care) } \\
\hline \multicolumn{6}{|c|}{ Test for heterogeneity chi-square $=8.10 \mathrm{df}=1 \mathrm{I} p=0.70 \mathrm{I}^{2}=0.0 \%$} \\
\hline \multicolumn{6}{|c|}{ Test for overall effect $z=3.59 \quad p=0.0003$} \\
\hline
\end{tabular}

\section{Analysis 01.02. Comparison 0I Self Management versus Usual Care, Outcome 02 Hospitalisations (mean)}

Review: Self-management education and regular practitioner review for adults with asthma

Comparison: 0 I Self Management versus Usual Care

Outcome: 02 Hospitalisations (mean)

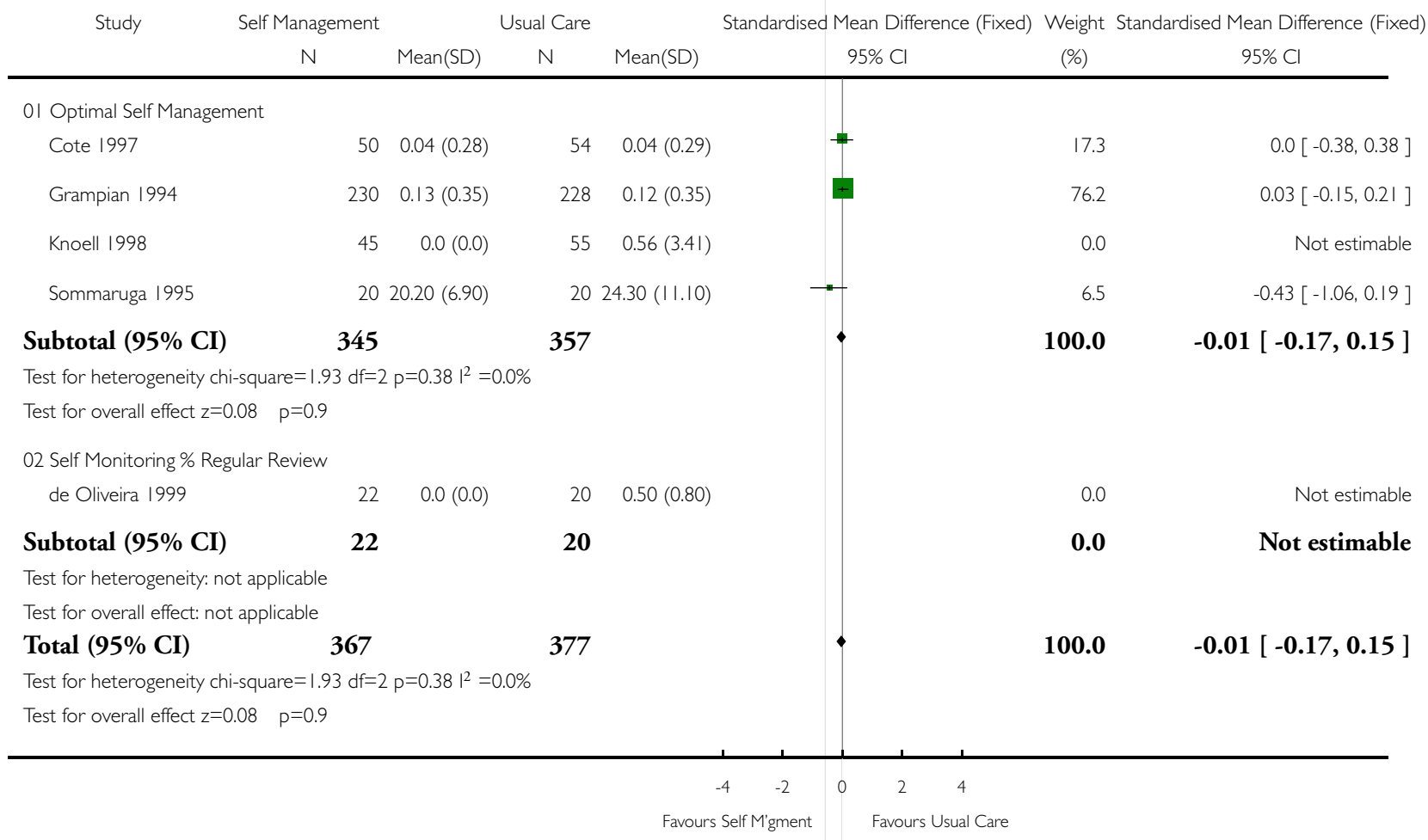




\section{Analysis 0I.03. Comparison 0I Self Management versus Usual Care, Outcome 03 ER Visits (\% subjects)}

Review: Self-management education and regular practitioner review for adults with asthma

Comparison: OI Self Management versus Usual Care

Outcome: 03 ER Visits (\% subjects)

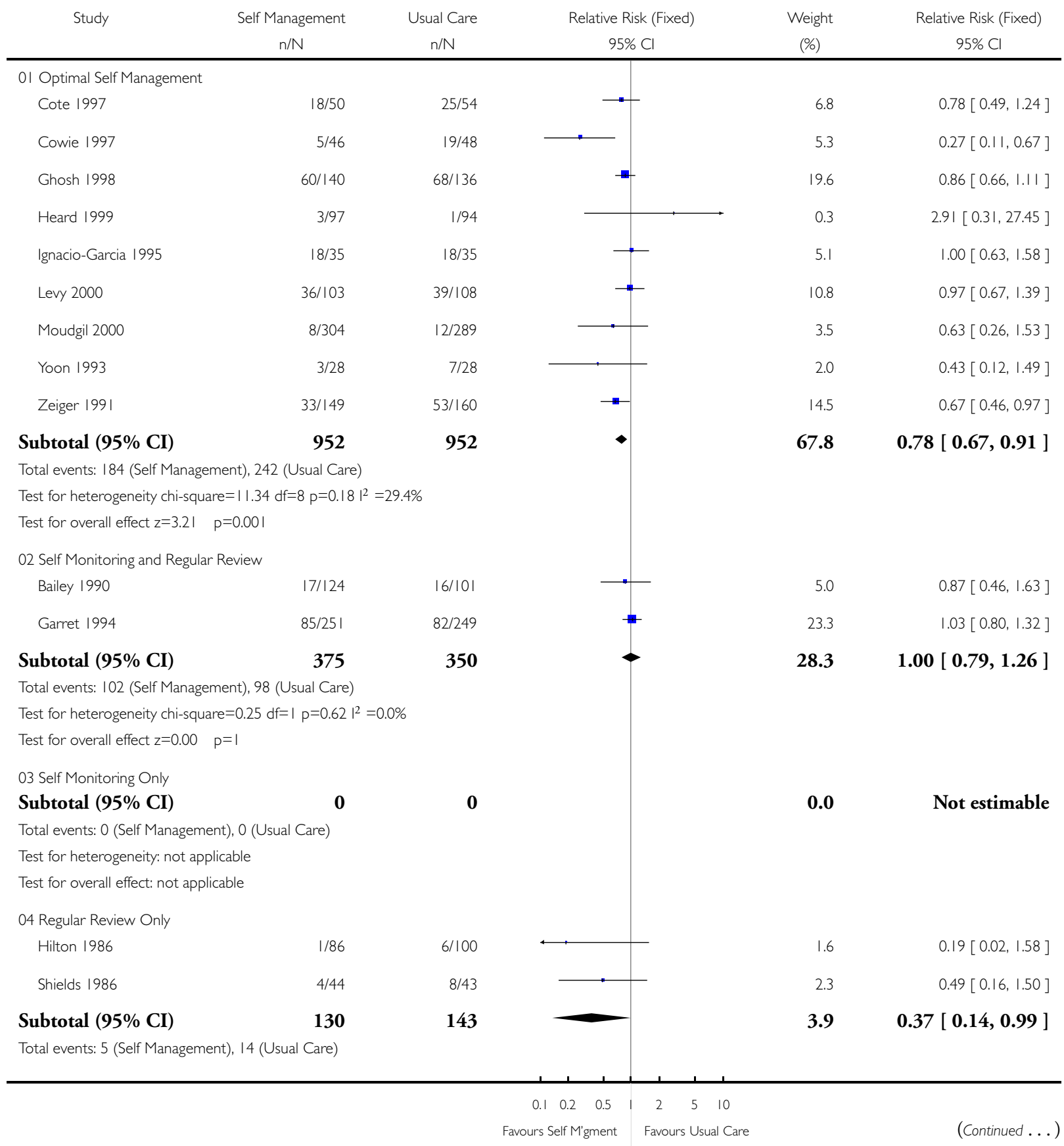




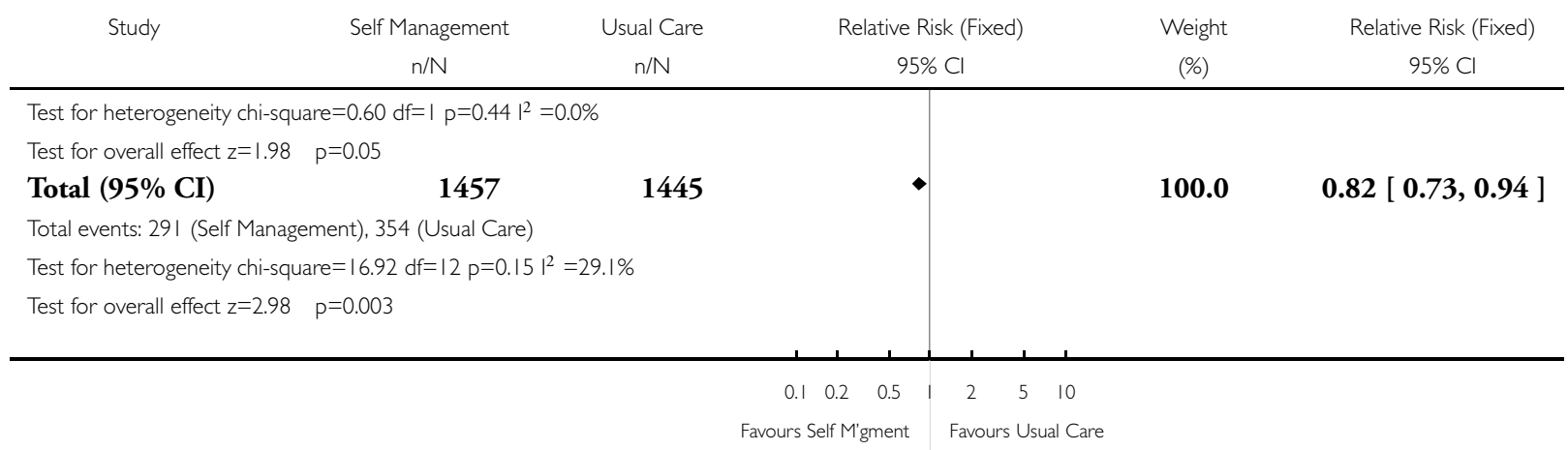

\section{Analysis 01.04. Comparison 0 I Self Management versus Usual Care, Outcome 04 ER Visits (Mean)}

Review: Self-management education and regular practitioner review for adults with asthma

Comparison: OI Self Management versus Usual Care

Outcome: 04 ER Visits (Mean)

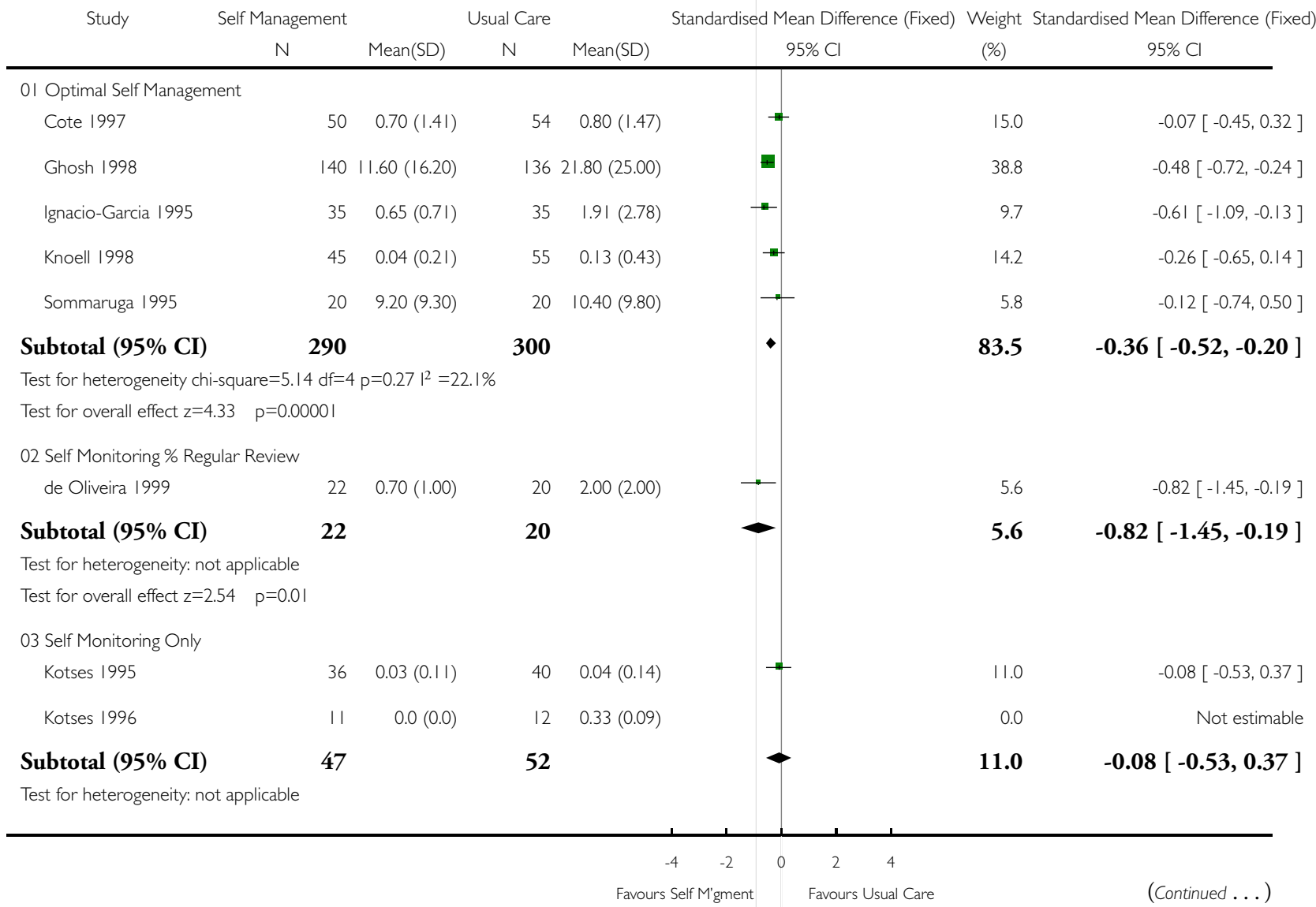




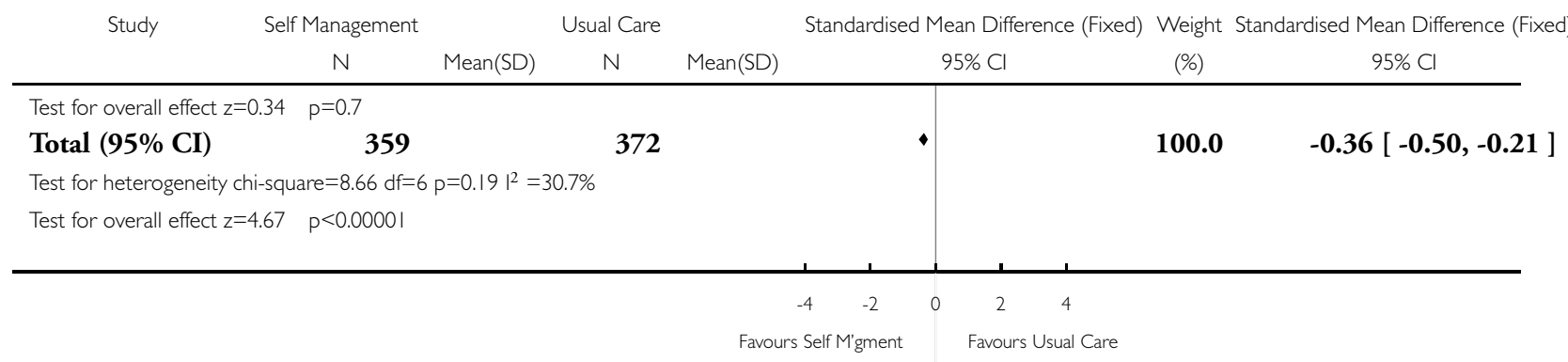

\section{Analysis 01.05. Comparison 0I Self Management versus Usual Care, Outcome 05 Unscheduled Dr Visits (mean)}

Review: Self-management education and regular practitioner review for adults with asthma

Comparison: 0 I Self Management versus Usual Care

Outcome: 05 Unscheduled Dr Visits (mean)

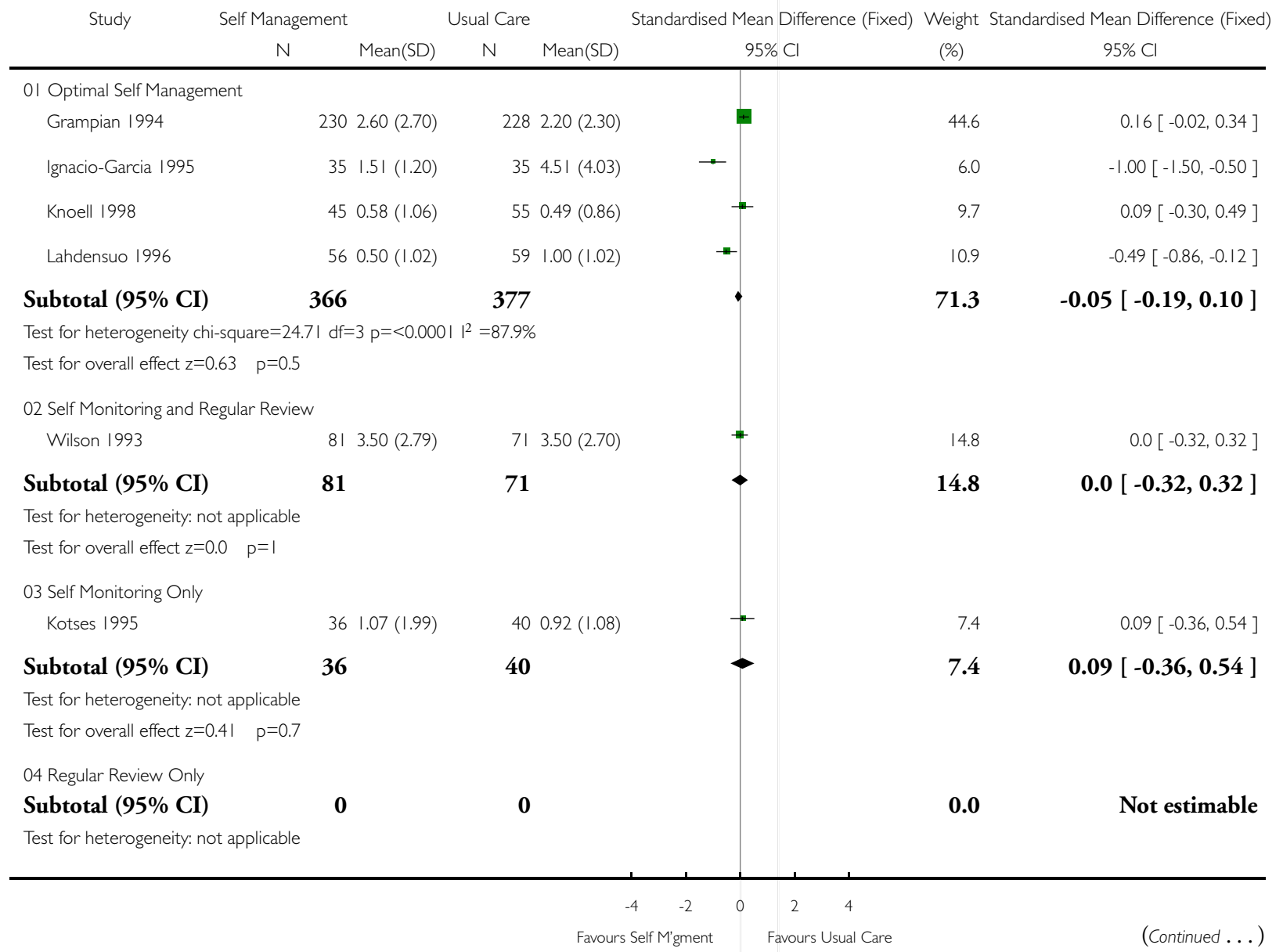




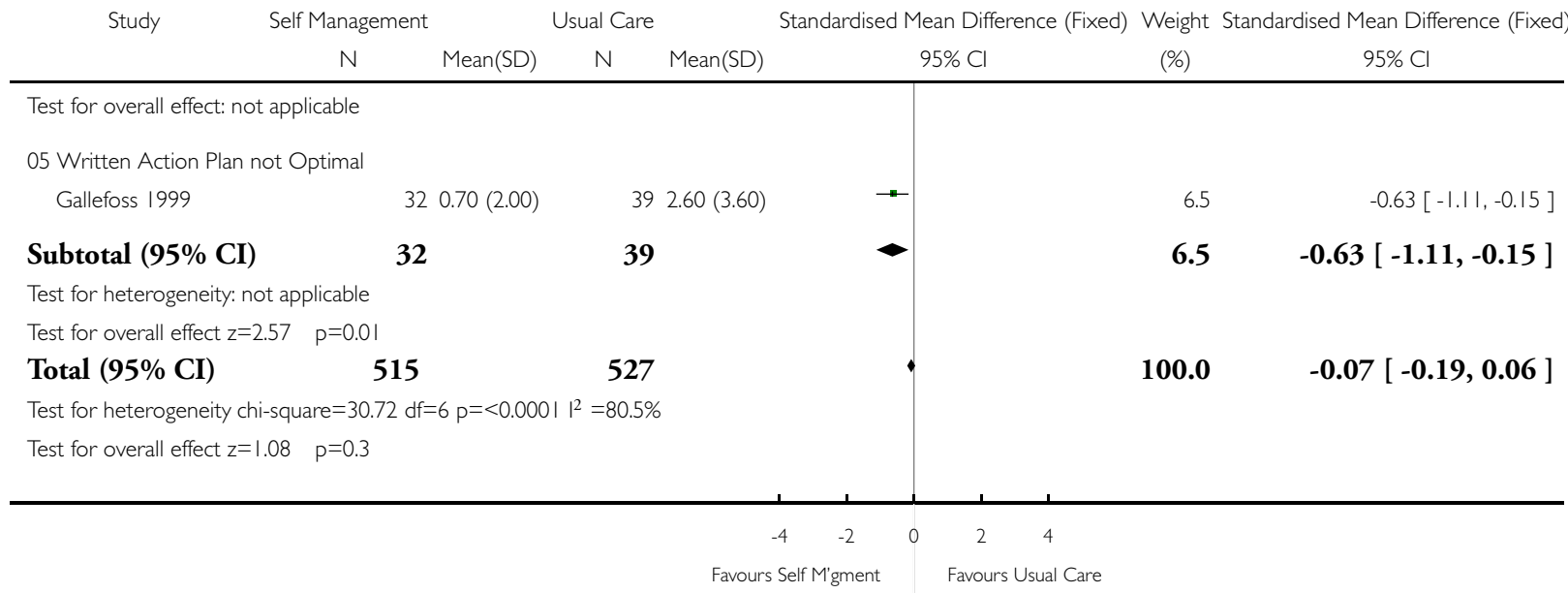

\section{Analysis 01.06. Comparison 0I Self Management versus Usual Care, Outcome 06 Unscheduled Dr Visits (\% subjects)}

Review: Self-management education and regular practitioner review for adults with asthma

Comparison: OI Self Management versus Usual Care

Outcome: 06 Unscheduled Dr Visits (\% subjects)

Study Self Management

Usual Care

Relative Risk (Fixed)

Weight

Relative Risk (Fixed)

$\mathrm{n} / \mathrm{N}$

$\mathrm{n} / \mathrm{N}$

$95 \% \mathrm{Cl}$

(\%)

$95 \% \mathrm{Cl}$

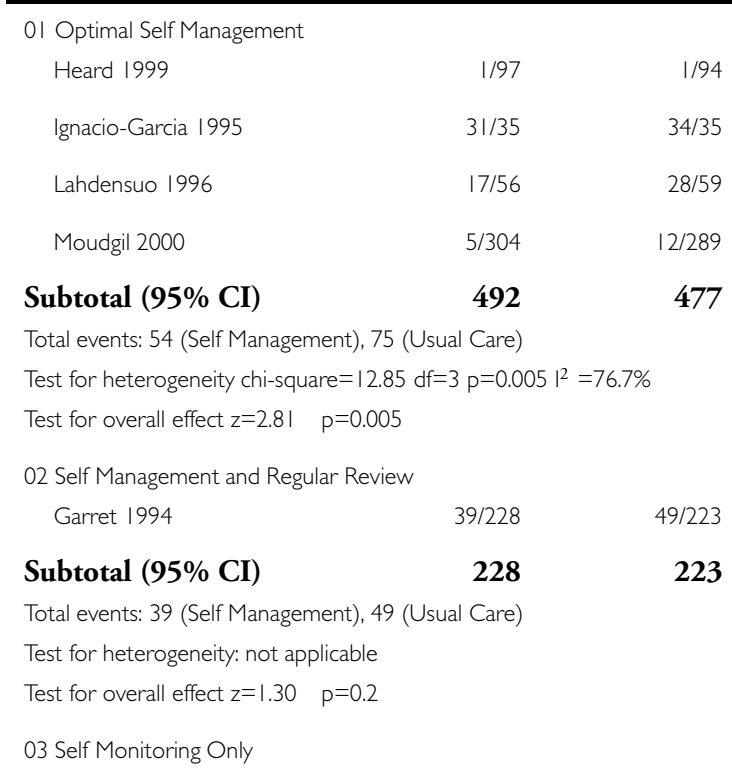

0.6

$0.97[0.06,15.27]$

20.3

$0.91[0.80,1.04]$

$0.64[0.40,1.03]$

Total events: 54 (Self Management), 75 (Usual Care)

16.3

$0.40[0.14,1.11]$

7.4

$0.73[0.58,0.91]$

44.6

$0.73[0.58,0.91]$

29.6

$0.78[0.53,1.14]$

29.6

$0.78[0.53,1.14]$

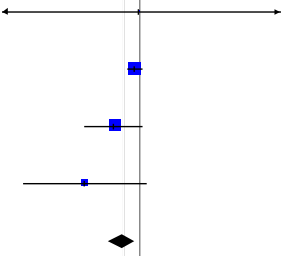




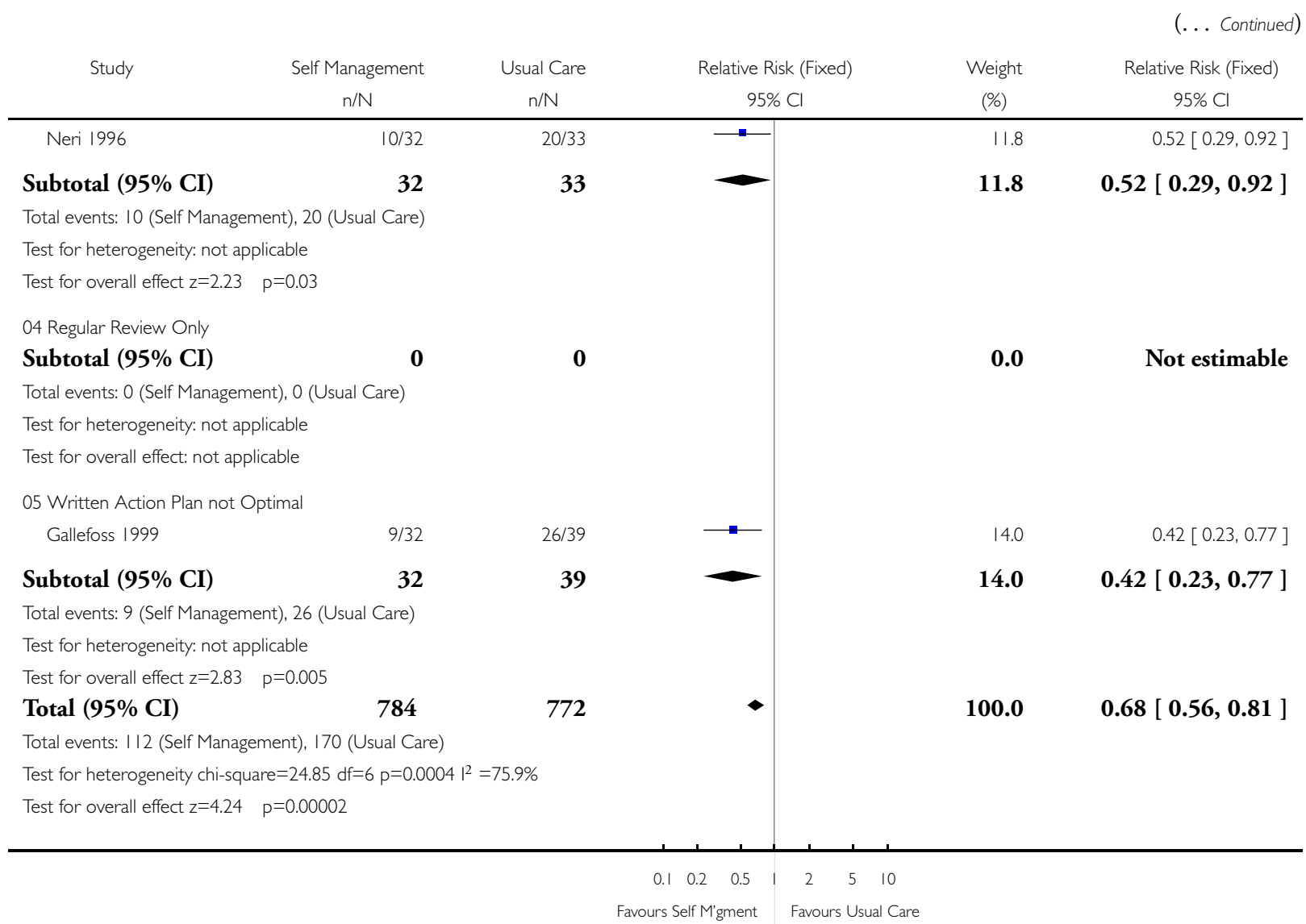


Analysis 01.07. Comparison 0I Self Management versus Usual Care, Outcome 07 Days off work (\% subjects) Review: Self-management education and regular practitioner review for adults with asthma

Comparison: 0 I Self Management versus Usual Care

Outcome: 07 Days off work (\% subjects)

\begin{tabular}{|c|c|c|c|c|c|}
\hline Study & $\begin{array}{c}\text { Self Management } \\
n / N\end{array}$ & $\begin{array}{c}\text { Usual Care } \\
n / N\end{array}$ & $\begin{array}{c}\text { Relative Risk (Fixed) } \\
95 \% \mathrm{Cl}\end{array}$ & $\begin{array}{l}\text { Weight } \\
(\%)\end{array}$ & $\begin{array}{c}\text { Relative Risk (Fixed) } \\
95 \% \mathrm{Cl}\end{array}$ \\
\hline \multicolumn{6}{|l|}{ OI Optimal Self Management } \\
\hline Heard 1999 & $34 / 97$ & $36 / 94$ & $\rightarrow$ & 20.8 & $0.92[0.63,1.33]$ \\
\hline Ignacio-Garcia 1995 & $24 / 35$ & $29 / 35$ & $\rightarrow$ & 16.5 & $0.83[0.63,1.08]$ \\
\hline Lahdensuo 1996 & $13 / 56$ & $25 / 59$ & $\longrightarrow$ & 13.8 & $0.55[0.31,0.96]$ \\
\hline Yoon 1993 & $5 / 28$ & $4 / 28$ & 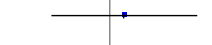 & 2.3 & $1.25[0.37,4.17]$ \\
\hline Subtotal $(95 \% \mathrm{CI})$ & 216 & 216 & $\bullet$ & 53.4 & $0.81[0.65,1.01]$ \\
\hline \multicolumn{6}{|c|}{ Total events: 76 (Self Management), 94 (Usual Care) } \\
\hline \multicolumn{6}{|c|}{ Test for heterogeneity chi-square $=2.80 \mathrm{df}=3 \mathrm{p}=0.42 \mathrm{I}^{2}=0.0 \%$} \\
\hline \multicolumn{6}{|c|}{ Test for overall effect $z=1.89 \quad p=0.06$} \\
\hline \multicolumn{6}{|c|}{02 Self Monitoring and Regular Review } \\
\hline Garret 1994 & $58 / 100$ & $57 / 90$ & 畐 & 34.1 & $0.92[0.73,1.15]$ \\
\hline Subtotal $(95 \% \mathrm{CI})$ & 100 & 90 & - & 34.1 & $0.92[0.73,1.15]$ \\
\hline \multicolumn{6}{|c|}{ Total events: 58 (Self Management), 57 (Usual Care) } \\
\hline \multicolumn{6}{|c|}{ Test for heterogeneity: not applicable } \\
\hline \multicolumn{6}{|c|}{ Test for overall effect $z=0.75 \quad p=0.5$} \\
\hline \multicolumn{6}{|l|}{03 Self Monitoring Only } \\
\hline Brewin 1995 & $0 / 12$ & $16 / 33$ & 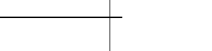 & 5.2 & $0.08[0.01,1.23]$ \\
\hline Neri 1996 & $7 / 32$ & $13 / 33$ & $\longrightarrow$ & 7.3 & $0.56[0.25,1.21]$ \\
\hline Subtotal $(95 \% \mathrm{CI})$ & 44 & 66 & - & 12.5 & $0.36[0.16,0.78]$ \\
\hline \multicolumn{6}{|c|}{ Total events: 7 (Self Management), 29 (Usual Care) } \\
\hline \multicolumn{6}{|c|}{ Test for heterogeneity chi-square $=2.39 \mathrm{df}=|\mathrm{p}=0.12|^{2}=58.2 \%$} \\
\hline \multicolumn{6}{|c|}{ Test for overall effect $z=2.58 \quad p=0.01$} \\
\hline \multicolumn{6}{|l|}{04 Regular Review Only } \\
\hline Subtotal $(95 \% \mathrm{CI})$ & $\mathbf{0}$ & $\mathbf{0}$ & & 0.0 & Not estimable \\
\hline \multicolumn{6}{|c|}{ Total events: 0 (Self Management), 0 (Usual Care) } \\
\hline \multicolumn{6}{|c|}{ Test for heterogeneity: not applicable } \\
\hline \multicolumn{6}{|c|}{ Test for overall effect: not applicable } \\
\hline Total $(95 \% \mathrm{CI})$ & 360 & 372 & $\bullet$ & 100.0 & $0.79[0.67,0.93]$ \\
\hline \multicolumn{6}{|c|}{ Total events: I4I (Self Management), I80 (Usual Care) } \\
\hline \multicolumn{6}{|c|}{ Test for heterogeneity chi-square $=8.04 \mathrm{df}=6 \mathrm{p}=0.24 \mathrm{I}^{2}=25.4 \%$} \\
\hline Test for overall effect $z=2.90$ & $=0.004$ & & & & \\
\hline
\end{tabular}




\section{Analysis 01.08. Comparison 0I Self Management versus Usual Care, Outcome 08 Days off work (mean)}

Review: Self-management education and regular practitioner review for adults with asthma

Comparison: OI Self Management versus Usual Care

Outcome: 08 Days off work (mean)

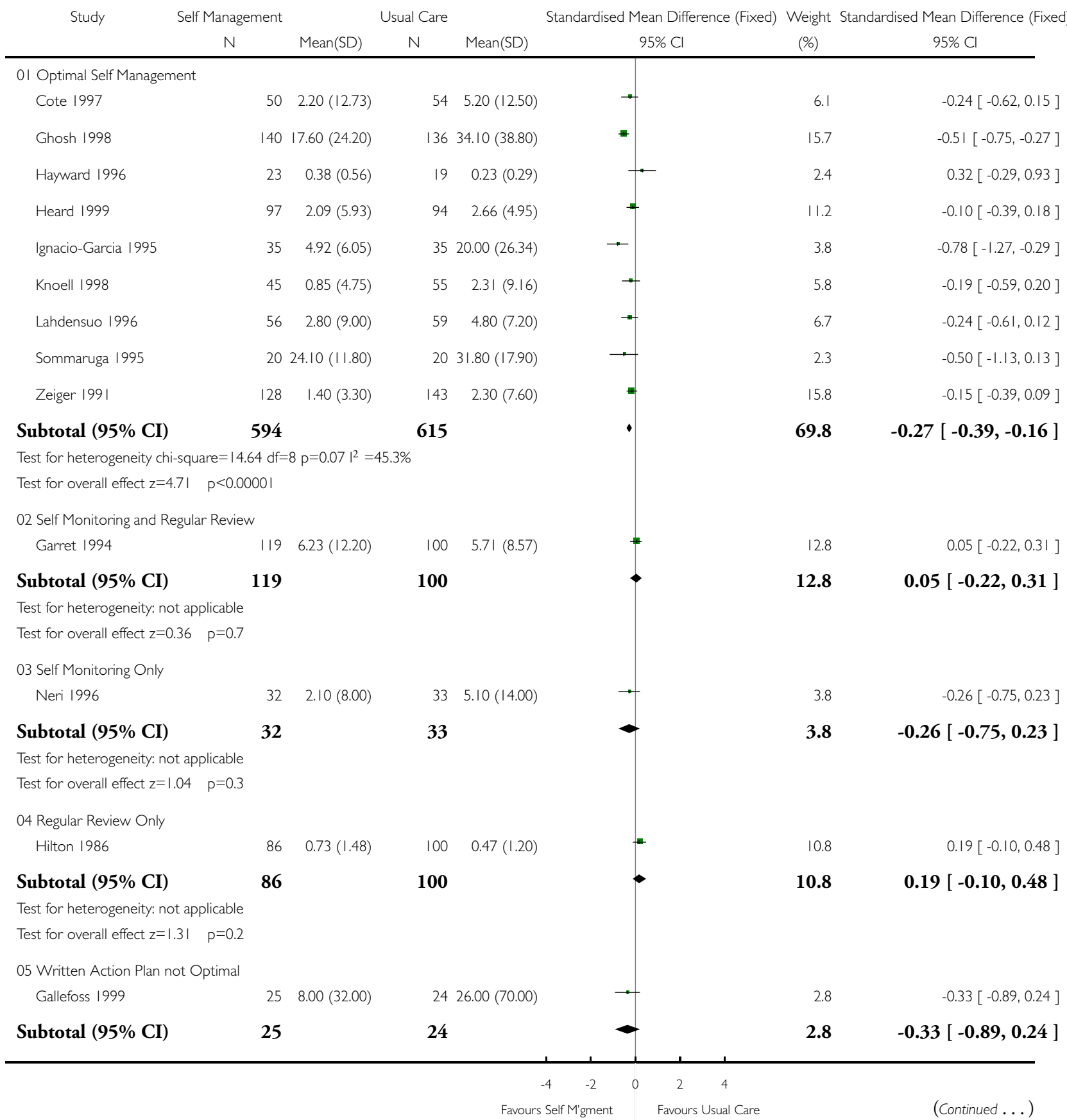


(... Continued)

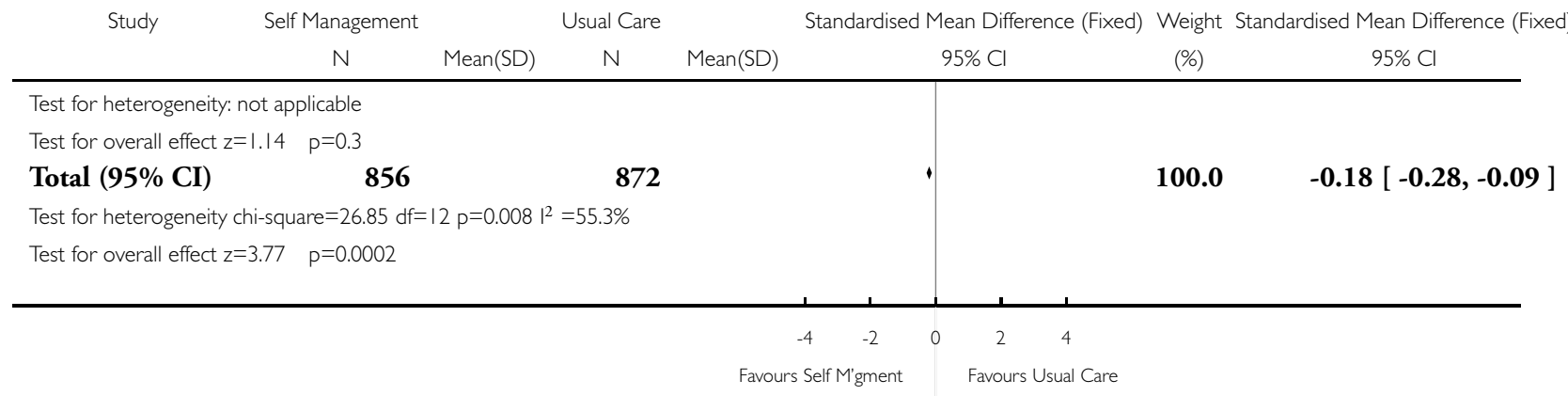

\section{Analysis 01.09. Comparison 01 Self Management versus Usual Care, Outcome 09 Nocturnal Asthma (\% subjects)}

Review: Self-management education and regular practitioner review for adults with asthma

Comparison: 0 I Self Management versus Usual Care

Outcome: 09 Nocturnal Asthma (\% subjects)

Study

Self Management

Usual Care

Relative Risk (Fixed)

95\% Cl

Weight

Relative Risk (Fixed)

$n / N$

$\mathrm{n} / \mathrm{N}$

\%) 95\% Cl

OI Optimal Self Management

Heard 1999

$7 / 97$

19/94

Ignacio-Garcia 1995

$34 / 35$

$34 / 35$

Zeiger 1991

| $1 / 149$

$40 / 160$

281

289

Subtotal (95\% CI)

Total events: 52 (Self Management), 93 (Usual Care)

Test for heterogeneity chi-square $=\mid 94.54 \mathrm{df}=2 \mathrm{p}=<0.000 \mathrm{I} \mathrm{I}^{2}=99.0 \%$

Test for overall effect $z=4.66 \quad p<0.0000$ ।

02 Self Monitoring and Regular Review

$\begin{array}{lrr}\text { Allen } 1995 & 12 / 56 & 20 / 57 \\ \text { Garret } 1994 & 69 / 230 & 85 / 223\end{array}$

Subtotal (95\% CI)

286

280

Total events: 8I (Self Management), 105 (Usual Care)

Test for heterogeneity chi-square $=0.56 \mathrm{df}=|\mathrm{p}=0.45|^{2}=0.0 \%$

Test for overall effect $z=2.32 \quad p=0.02$

Total (95\% CI) $\quad \mathbf{5 6 7}$

$567 \quad 569$

$\square$

$0.36[0.16,0.81]$
$1.00[0.92,1.08]$
$0.30[0.16,0.55]$

Total events: 133 (Self Management), 198 (Usual Care)

Test for heterogeneity chi-square $=107.02 \mathrm{df}=4 \mathrm{p}=<0.000 \mid \mathrm{I}^{2}=96.3 \%$

Test for overall effect $z=4.66 \quad p<0.0000$ I 


\section{Analysis 0I.I0. Comparison 0I Self Management versus Usual Care, Outcome I0 FEVI (mean)}

Review: Self-management education and regular practitioner review for adults with asthma Comparison: OI Self Management versus Usual Care

Outcome: $10 \mathrm{FEVI}$ (mean)

Study Self Management

Usual Care

Standardised Mean Difference (Fixed) Weight Standardised Mean Difference (Fixed) N

Mean(SD) N Mean(SD)

$95 \% \mathrm{Cl}$

(\%) $95 \% \mathrm{Cl}$

OI Optimal Self Management

Grampian $1994 \quad 25074.60(27.80) \quad 26075.40(27.70)$

Ignacio-Garcia 1995

$3580.45(19.52)$

$3565.48(22.01)$

Jones 1995

$3383.20(18.00)$

$3981.20(18.30)$

Lahdensuo 1996

$5680.90(16.10)$

$5979.40(15.60)$

Yoon 1993

Zeiger 1991

$28 \quad 2.79(0.81)$

$28 \quad 2.8 \mid(0.77)$

$9292.90(22.60)$

$9288.70(21.90)$

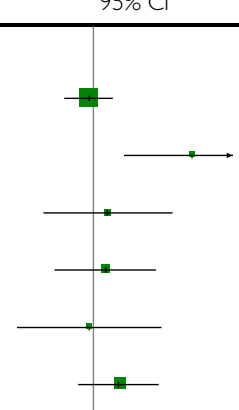

513

494

Subtotal (95\% CI)

$.76 d f=5 p=\left.0.12\right|^{2}=42.9 \%$

Test for heterogeneity chi-square $=8.76$

Test for overall effect $z=1.32 \quad p=0.2$

02 Self Management and Regular Review

Subtotal (95\% CI)

0

Test for heterogeneity: not applicable

Test for overall effect: not applicable

03 Self Monitoring Only

$$
\text { Neri } 1996
$$

Subtotal (95\% CI)

Test for heterogeneity: not applicable

Test for overall effect $z=1.20 \quad p=0.2$

04 Regular Review Only

Subtotal (95\% CI)

0

0

Test for heterogeneity: not applicable

Test for overall effect: not applicable

Total (95\% CI)

0.0

Not estimable

94.0

Not estimable

$0.30[-0.19,0.79]$

6.0

$0.30[-0.19,0.79]$

Favours Usual Care

Favours Self M'gment 


\section{Analysis 0I.I I. Comparison 0I Self Management versus Usual Care, Outcome I I Peak Expiratory Flow}

(mean)

Review: Self-management education and regular practitioner review for adults with asthma

Comparison: OI Self Management versus Usual Care

Outcome: II Peak Expiratory Flow (mean)

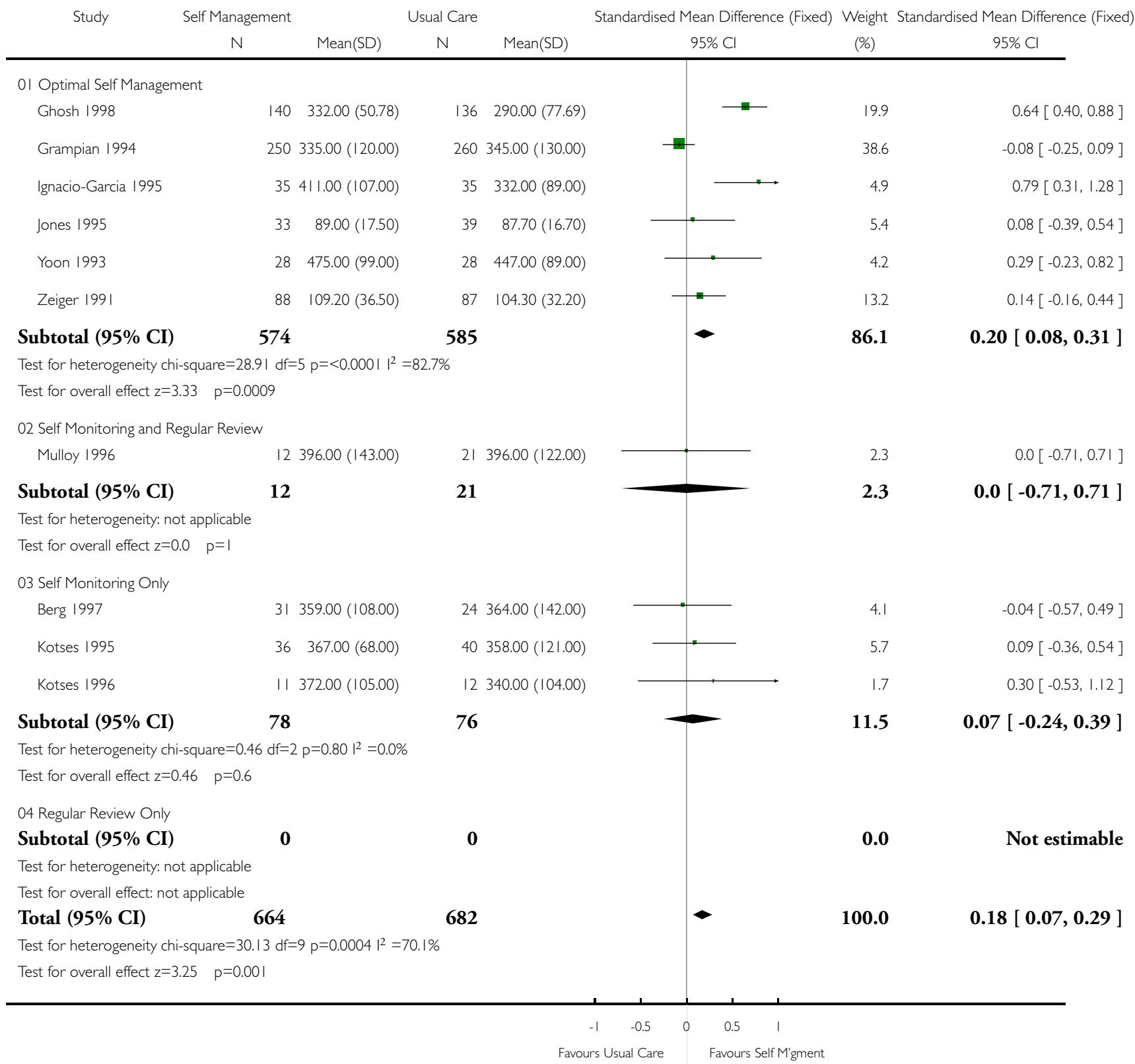




\section{Analysis 0I.I2. Comparison 0 I Self Management versus Usual Care, Outcome I2 Hospitalisations (mean total days)}

Review: Self-management education and regular practitioner review for adults with asthma

Comparison: OI Self Management versus Usual Care

Outcome: 12 Hospitalisations (mean total days)

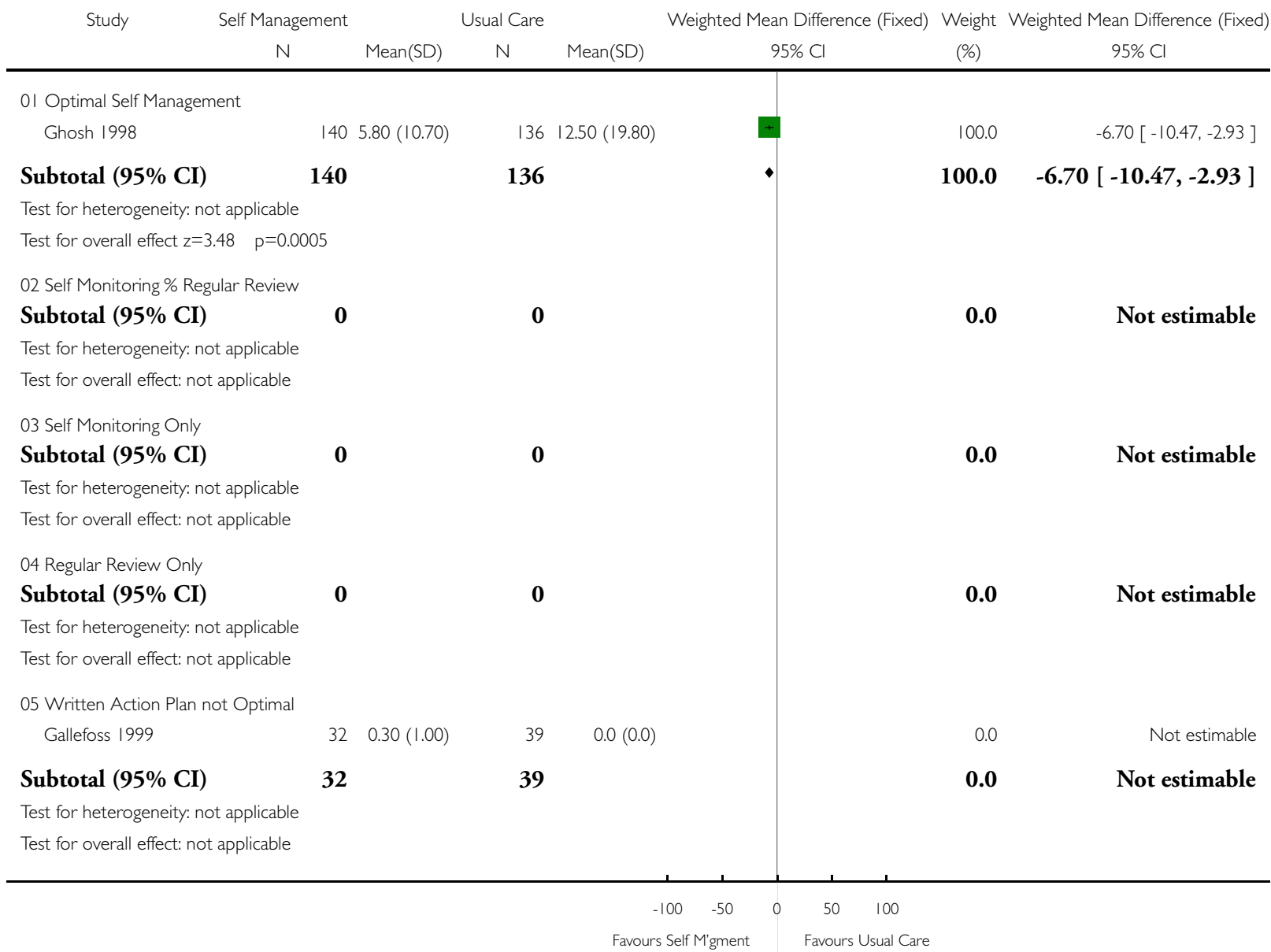


Analysis 0I.13. Comparison 0 I Self Management versus Usual Care, Outcome I3 Rescue Medication Use (\% subjects)

Review: Self-management education and regular practitioner review for adults with asthma

Comparison: 0 I Self Management versus Usual Care

Outcome: 13 Rescue Medication Use (\% subjects)

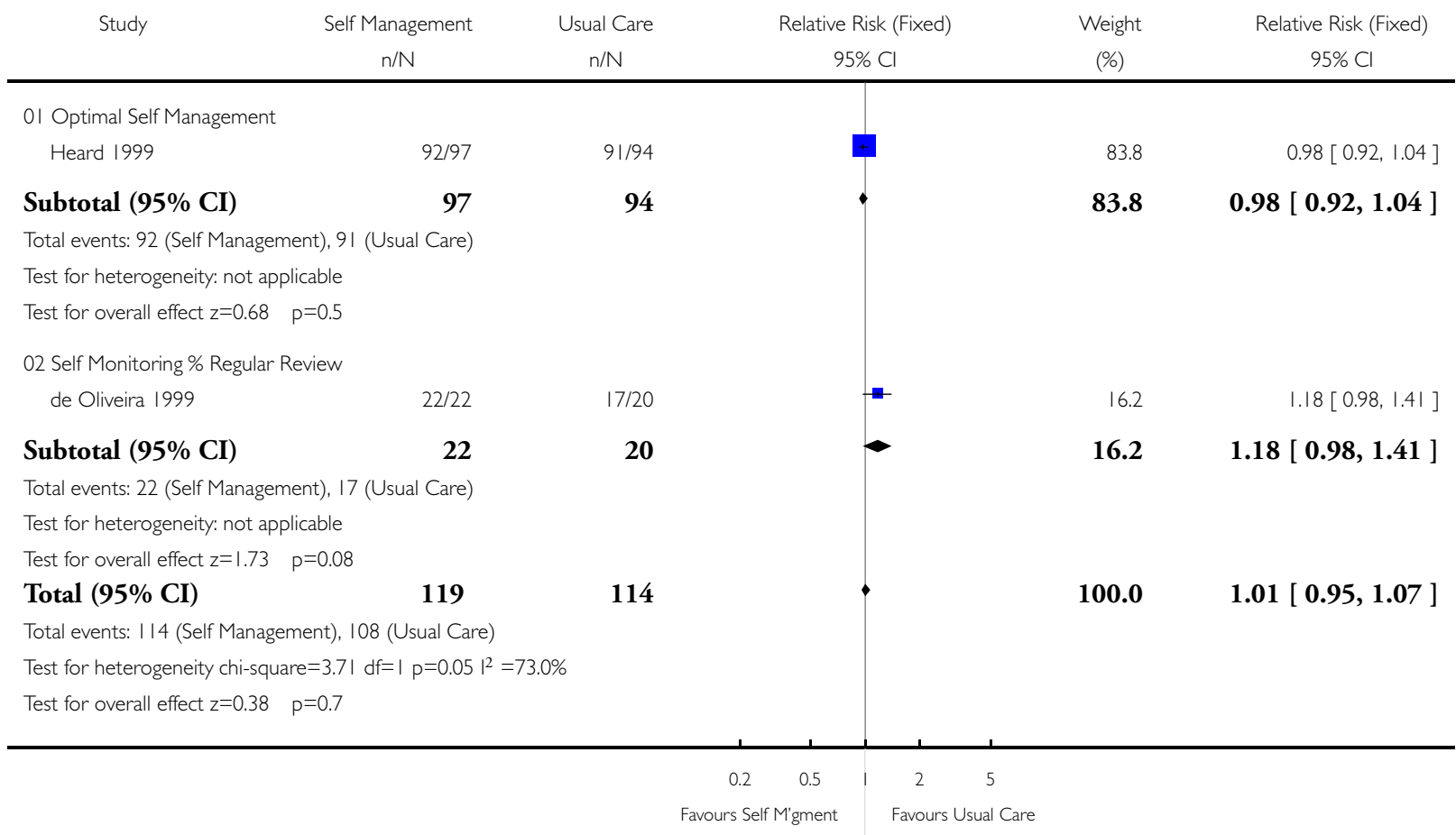


Analysis 0I.I4. Comparison OI Self Management versus Usual Care, Outcome I4 Quality of Life Total Score (mean)

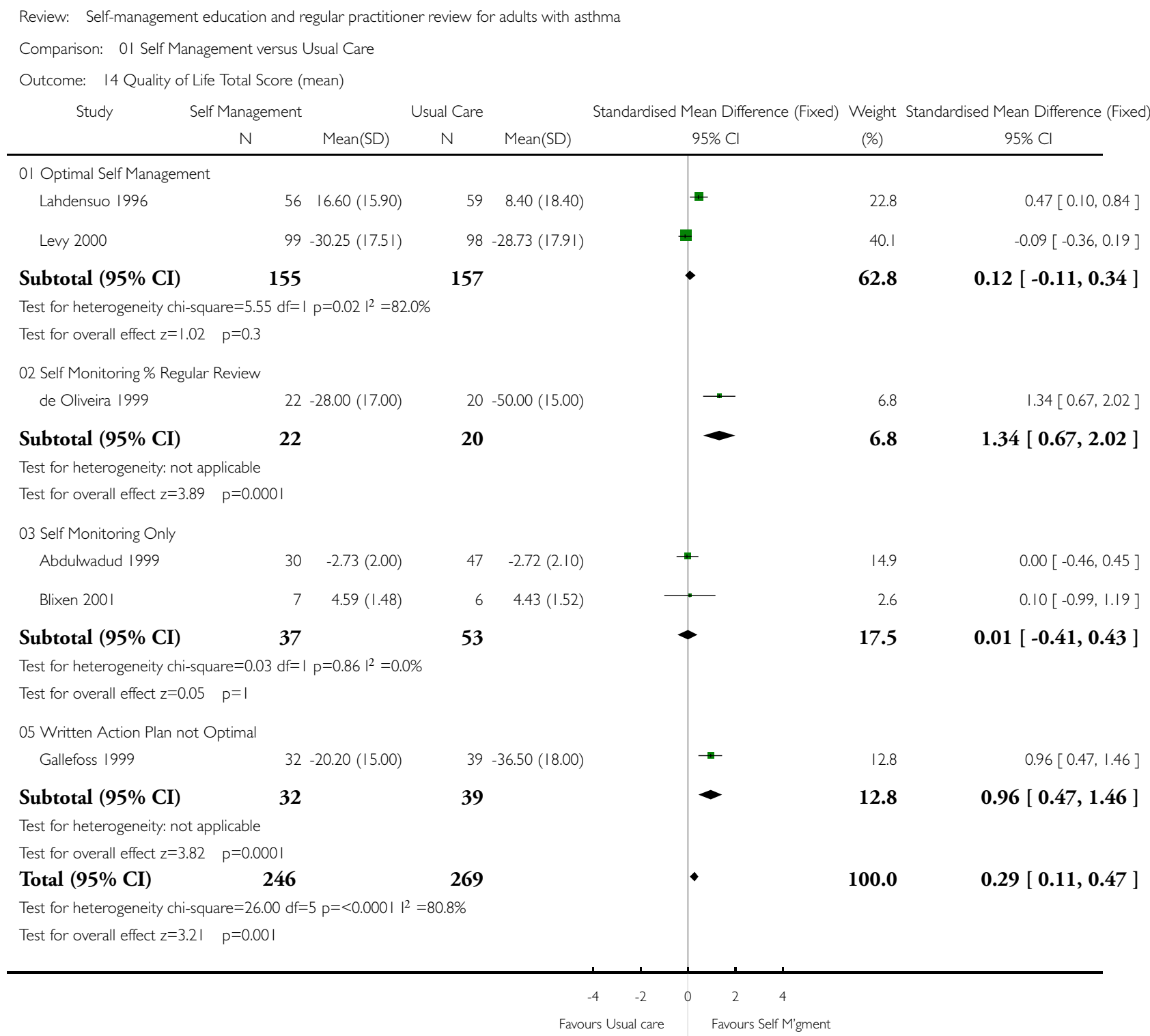




\section{Analysis 0I.15. Comparison 0I Self Management versus Usual Care, Outcome I5 Quality of Life Impact}

(mean)

Review: Self-management education and regular practitioner review for adults with asthma

Comparison: 0 I Self Management versus Usual Care

Outcome: 15 Quality of Life Impact (mean)

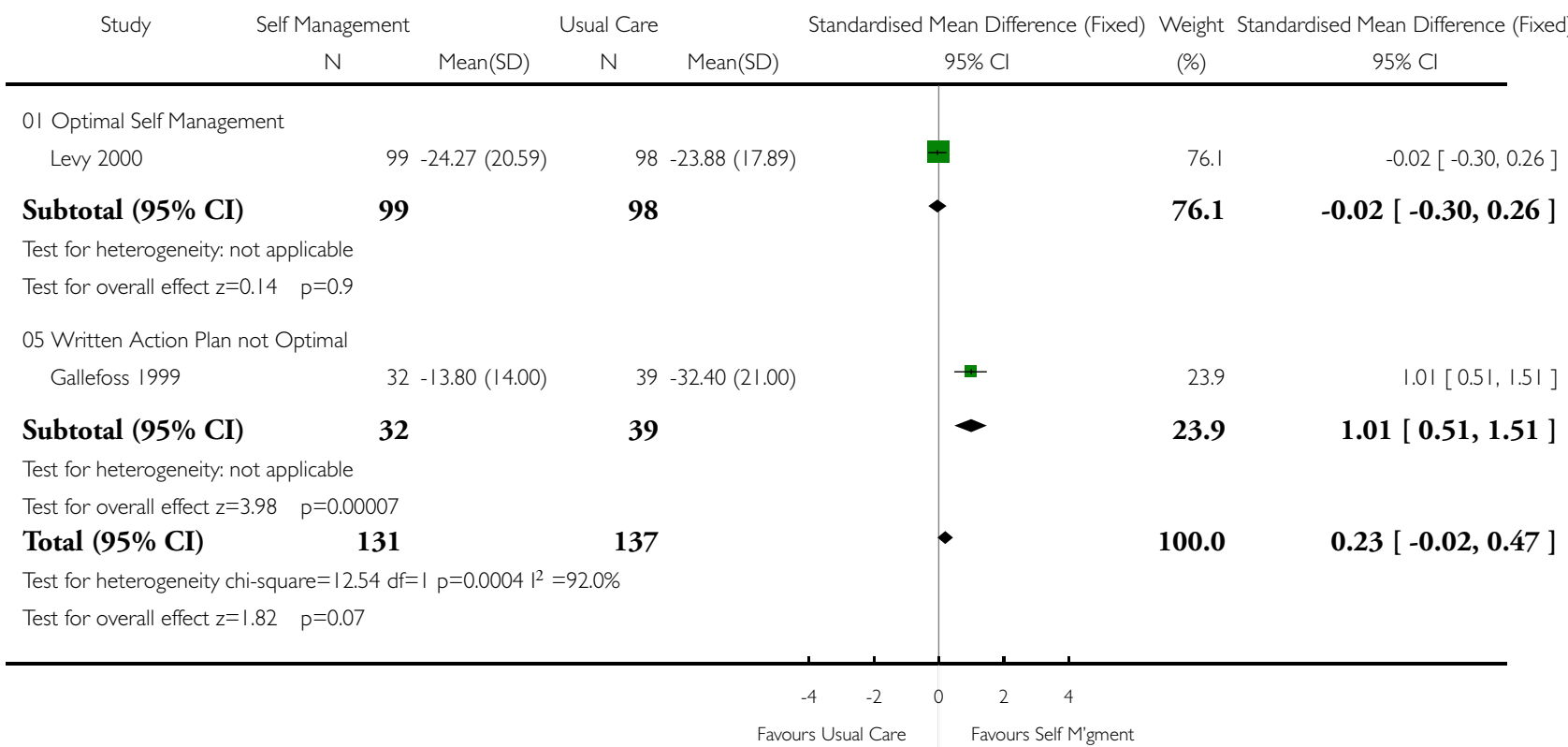

\section{Analysis 01.16. Comparison 0I Self Management versus Usual Care, Outcome I6 Quality of Life Activity (mean)}

Review: Self-management education and regular practitioner review for adults with asthma

Comparison: OI Self Management versus Usual Care

Outcome: 16 Quality of Life Activity (mean)

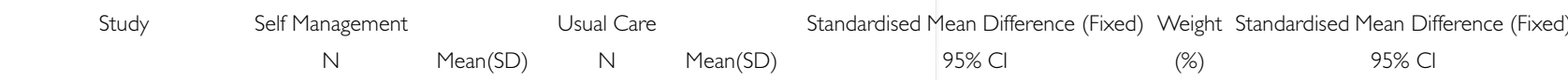

OI Optimal Self Management

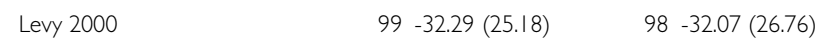

Subtotal (95\% CI)

Test for heterogeneity: not applicable

Test for overall effect $z=0.06 \quad p=1$

03 Self Monitoring Only

Blixen 2001

Subtotal (95\% CI)

Test for heterogeneity: not applicable
99

98

$7 \quad 4.90(1.10) \quad 6 \quad 4.75(1.73)$

7
71.4

71.4

4.7

4.7
$-0.01[-0.29,0.27]$

$-0.01[-0.29,0.27]$

$0.10[-0.99,1.19]$

$0.10[-0.99,1.19]$ 


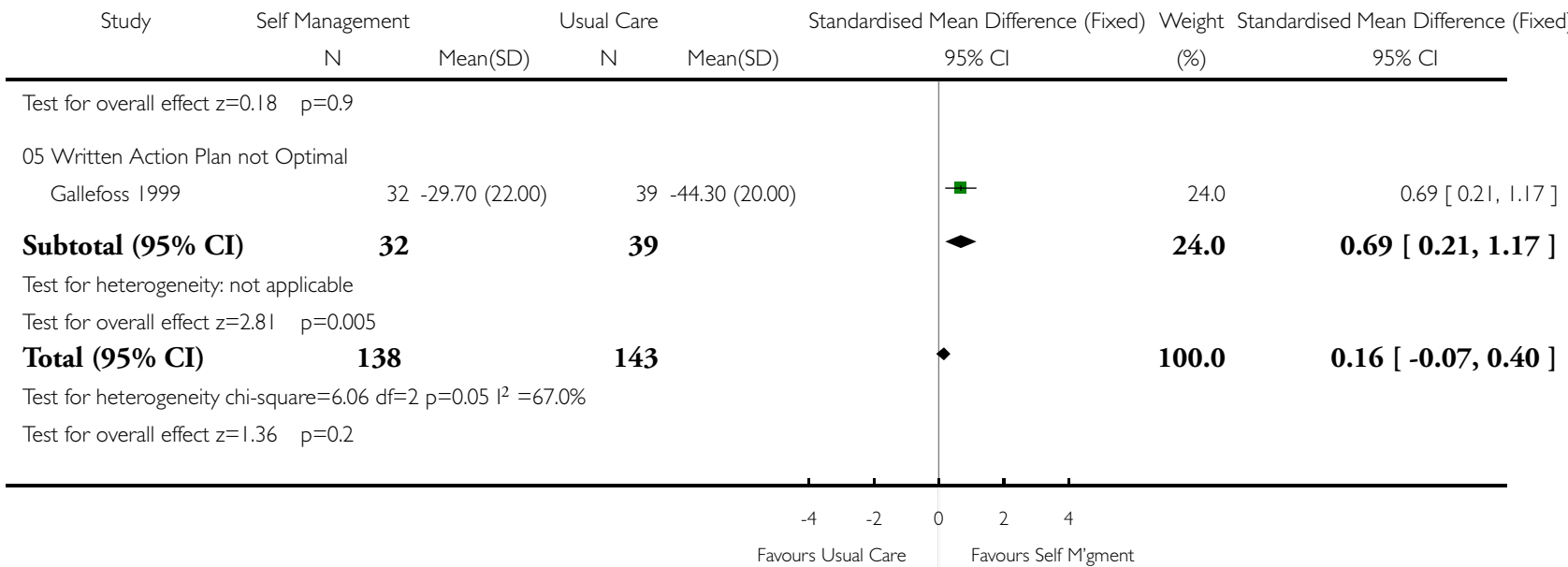

\section{Analysis 0I.I7. Comparison 0 I Self Management versus Usual Care, Outcome I7 Quality of Life Symptoms (mean)}

Review: Self-management education and regular practitioner review for adults with asthma

Comparison: 0 I Self Management versus Usual Care

Outcome: 17 Quality of Life Symptoms (mean)

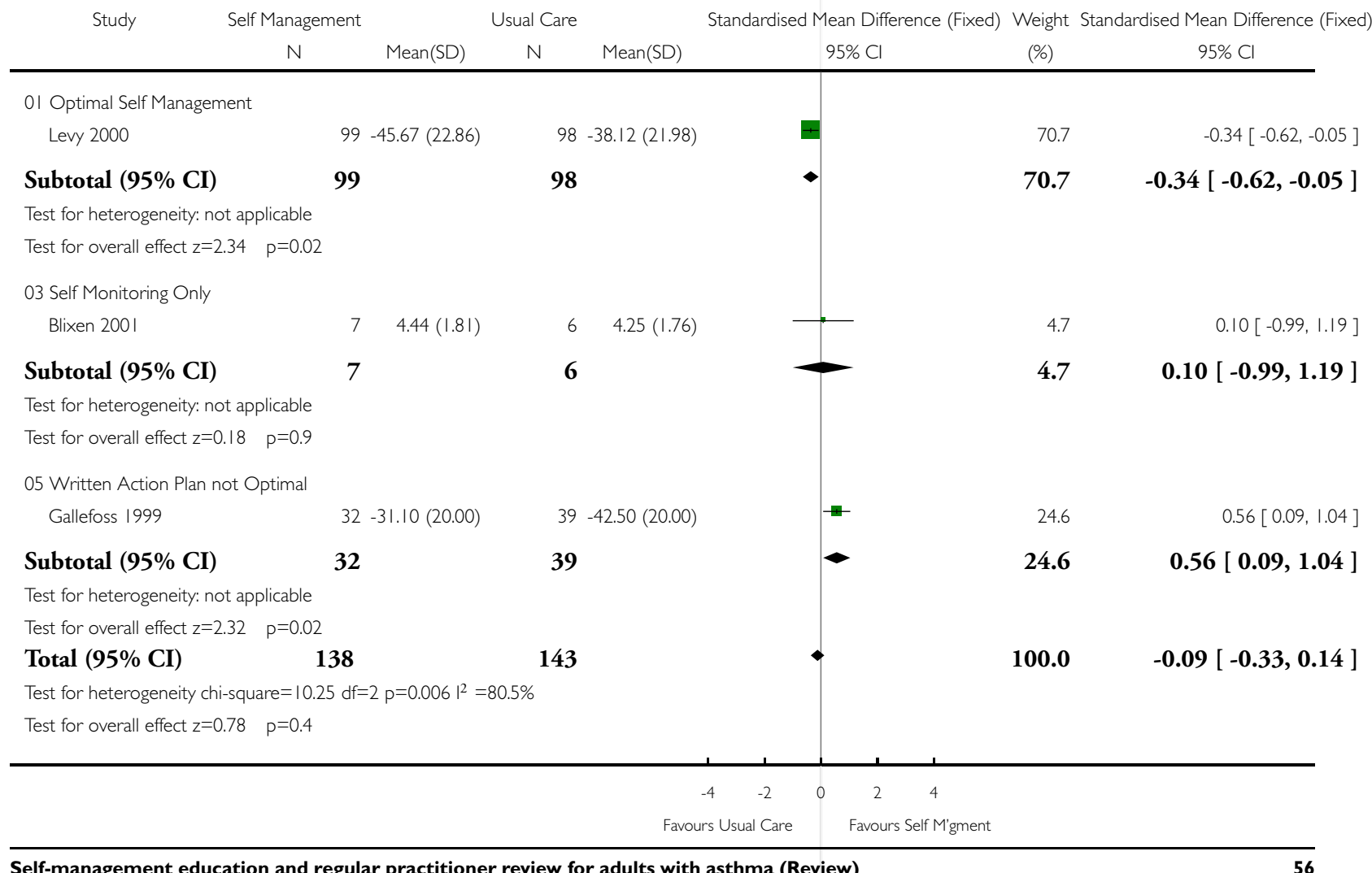

Copyright (c) 2008 The Cochrane Collaboration. Published by John Wiley \& Sons, Ltd 


\section{Analysis 0I.18. Comparison 0I Self Management versus Usual Care, Outcome I8 Total Direct Costs (mean)}

Review: Self-management education and regular practitioner review for adults with asthma

Comparison: 0 I Self Management versus Usual Care

Outcome: 18 Total Direct Costs (mean)

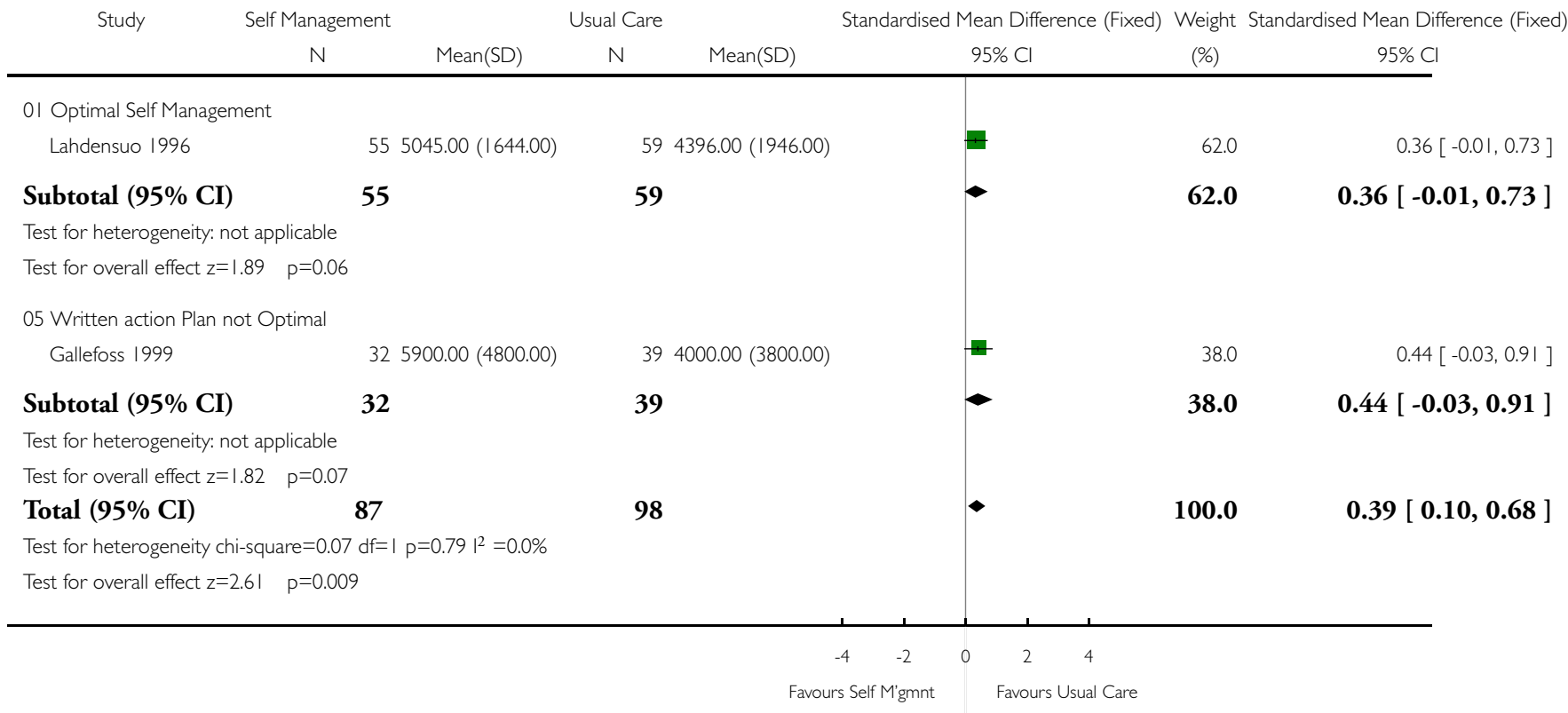

\section{Analysis 01.19. Comparison 0I Self Management versus Usual Care, Outcome 19 Total Indirect Costs (mean)}

Review: Self-management education and regular practitioner review for adults with asthma

Comparison: 0 I Self Management versus Usual Care

Outcome: 19 Total Indirect Costs (mean)

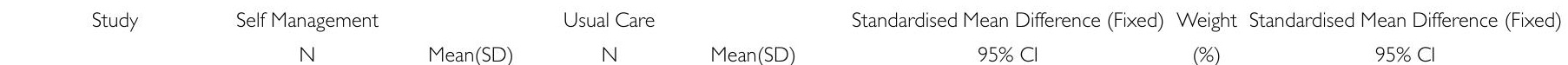

OI Optimal Self Management

Lahdensuo $1996 \quad 55 \quad 1 \mid 49.00(2794.00) \quad 59 \quad 3561.00(6331.00)$

Subtotal (95\% CI)

Test for heterogeneity: not applicable

Test for overall effect $z=2.54 \quad p=0.01$

05 Written Action Plan not Optimal

Gallefoss 1999

$324600.00(17300.00)$

$3911900.00(33500.00)$

Subtotal (95\% CI)

Test for heterogeneity: not applicable

Test for overall effect $z=1.10 \quad p=0.3$

Total (95\% CI)

87

Test for heterogeneity chi-square $=0.52 \mathrm{df}=\mid \mathrm{p}=0.47 \mathrm{|}^{2}=0.0 \%$

Test for overall effect $z=2.67 \quad p=0.007$
32

55

59

39

98
$95 \% \mathrm{Cl}$

$+$

$-$

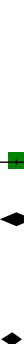

$-$
61.3

61.3

38.7

38.7

100.0
95\% C

$-0.48[-0.86,-0.11]$

$-0.48[-0.86,-0.11]$

$-0.26[-0.73,0.21]$

$-0.26[-0.73,0.21]$

$-0.40[-0.69,-0.11]$

Favours Self M'gmnt Favours Usual Care 


\section{Analysis 01.20. Comparison 0I Self Management versus Usual Care, Outcome 20 Total Costs (mean)}

Review: Self-management education and regular practitioner review for adults with asthma

Comparison: 01 Self Management versus Usual Care

Outcome: 20 Total Costs (mean)

$$
\text { Study Self Management }
$$$$
\text { N }
$$

Mean(SD)

Usual Care

N

Standardised Mean Difference (Fixed) Weight Standardised Mean Difference (Fixed 95\% Cl

OI Optimal Self Management

$$
\text { Lahdensuo } 1996
$$

$55 \quad 6194.00(4039.00)$ 55

Subtotal (95\% CI)

Test for heterogeneity: not applicable

Test for overall effect $z=1.63 p=0.1$

05 Written Action Plan not Optimal

$$
\text { Gallefoss } 1999
$$

Subtotal (95\% CI)

Test for heterogeneity: not applicable

Test for overall effect $z=0.77 \quad p=0.4$

Total (95\% CI)

87

Test for heterogeneity chi-square $=0.17 \mathrm{df}=\mid \mathrm{p}=0.68 \mathrm{I}^{2}=0.0 \%$

Test for overall effect $z=1.76 \quad p=0.08$

\section{$3210500.00(20500.00) \quad 39 \quad 16000.00(35400.00)$}

32

98
39

$597956.00(6866.00)$

59 95\% Cl

$95 \% \mathrm{Cl}$

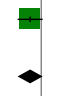

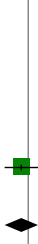

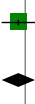

38.4

38.4

100.0

61.6

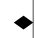
61.6
$-0.31[-0.68,0.06]$

$-0.31[-0.68,0.06$ ]
$-0.18[-0.65,0.29]$

$-0.18[-0.65,0.29]$

$-0.26[-0.55,0.03]$ 